قال اين شرف القيروانى:

"وأها "على بن الجهم” فرشيق الفهم... وله فى هال

الغزل الرصافية، وفى العتاب الدالية، ولو لهم

يكن له سواهما لكان أشعر الناس بهمها". 


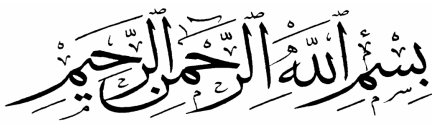

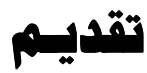

ينبت الثعر اء فى أرض الثعر الخصبة، ويشب الأدباء فى وطــن الأدب، الرفيع، ويترعرع الفن بين جو انح الشعر اء و الأدباء فيخرجونه فى درجة عاليـــة من الصفاء؛ وفى أدبنا العربى ما أكثر الثُعر اءو الأدباء ممن سار ذكـــرهم فــى

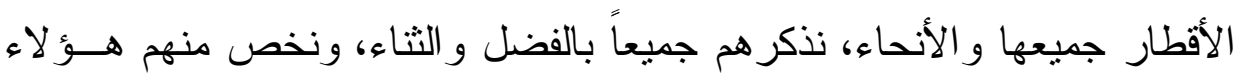

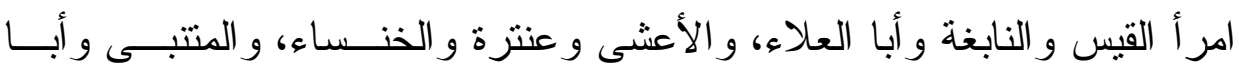

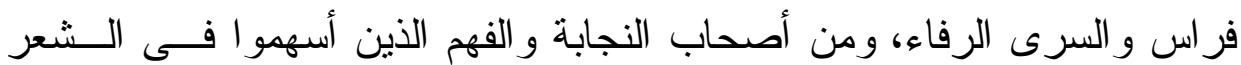
بأرفع سهم نذكر شـاعرنا "على بن الجهم" الذى قال فيه ابن شــرف القيروانــى

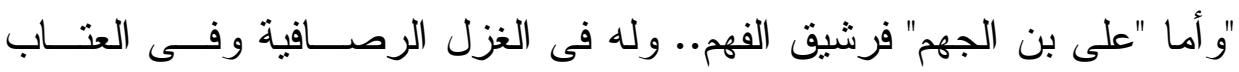

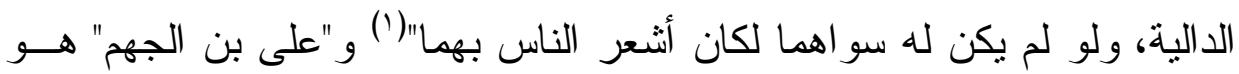
القائل:

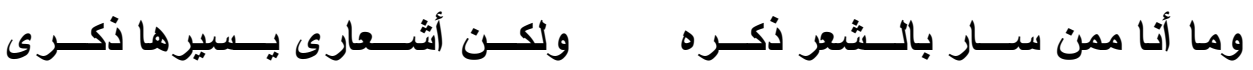

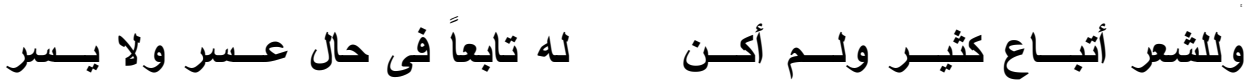

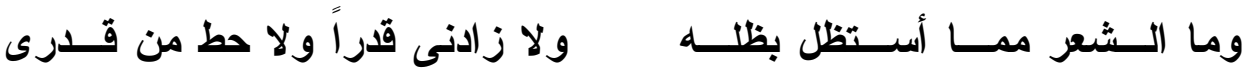
ولكــن إحسـسان الخليفــة "جعفـر" دعانى إلى ما قلت فيه من الـشعر

و القائل:

يعاقــب تأديبـــاً ويعفـــو تطـــولاً ويجزى على الحسنى ويعطى فيجزل 


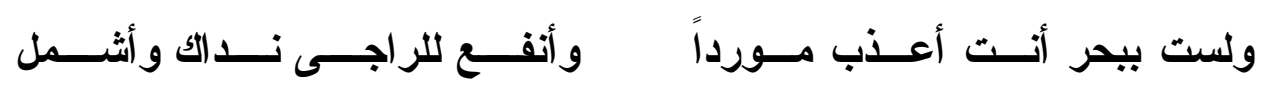
إنه صاحب الأبيات السابقة، وهى مصابيح كانثفة وأنوار متلألكئة فى سماء

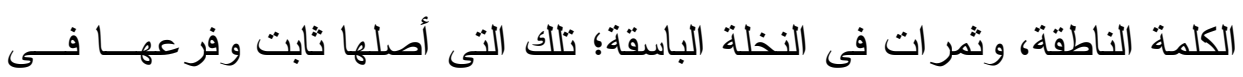
السماء.

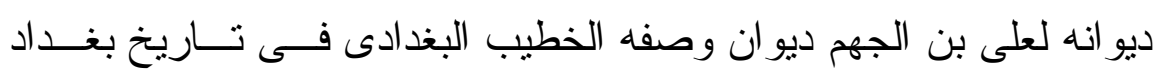

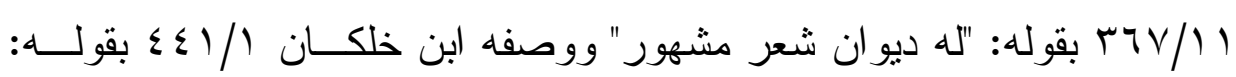

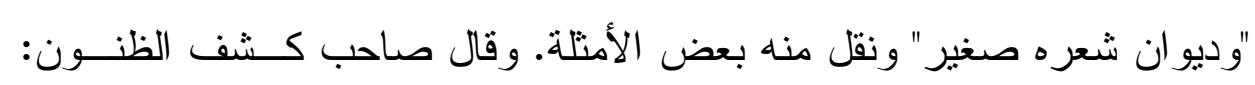

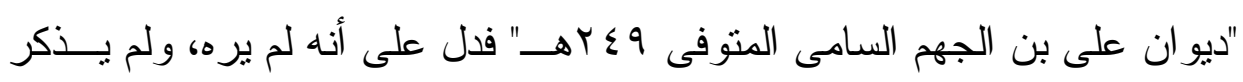

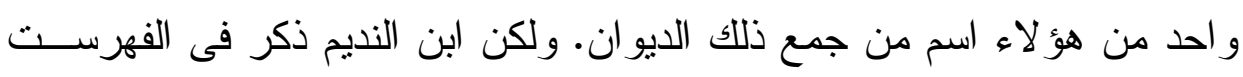

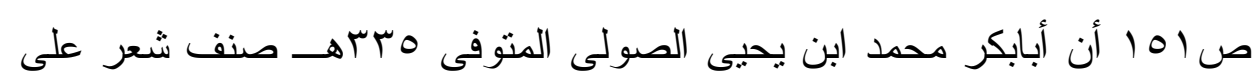

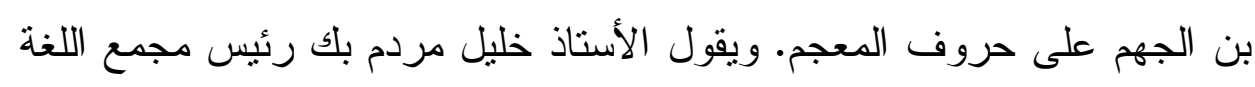

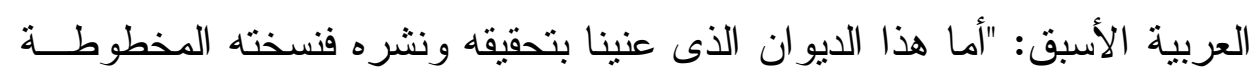

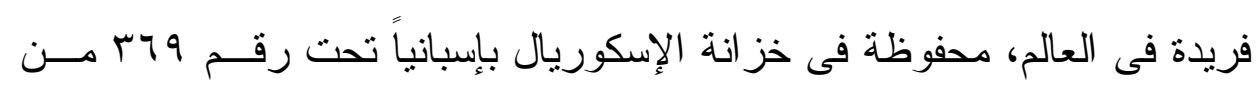

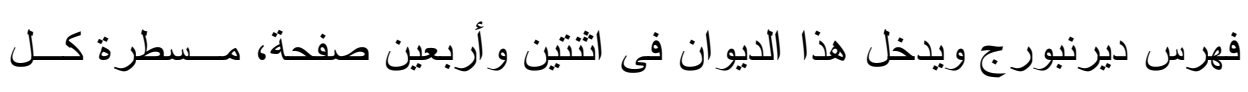

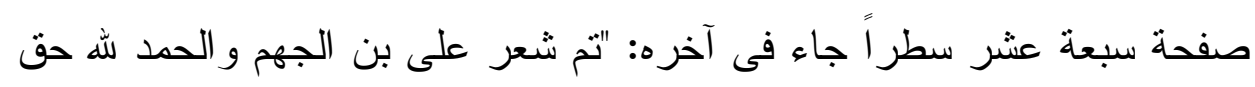

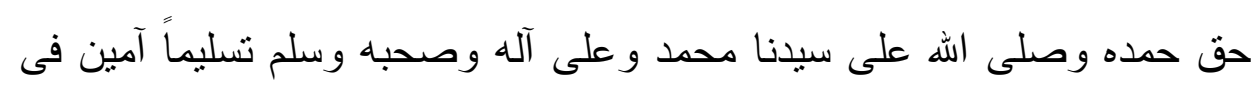

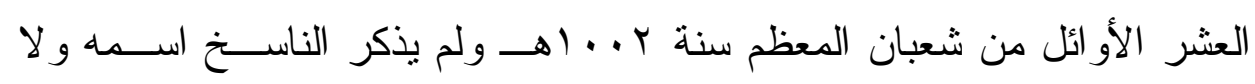

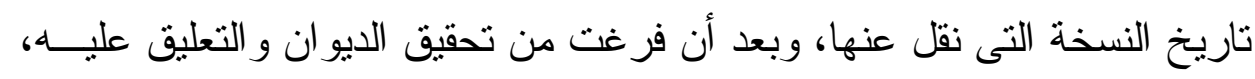

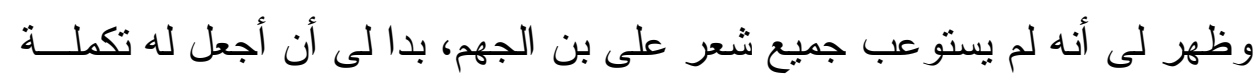

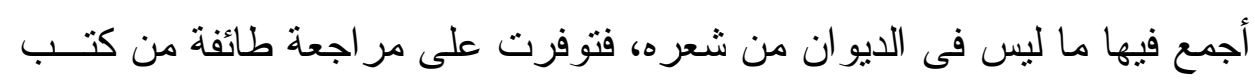

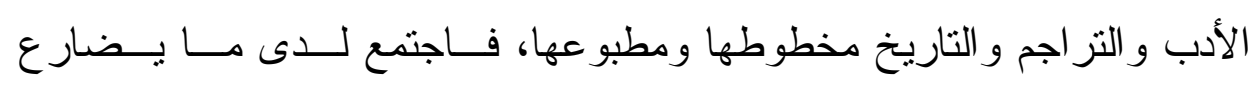

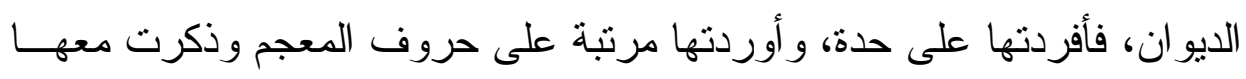


مصادرها، و ألحقتها بالديو ان، و لا أثنك فى أن ما فـانتى أكثــر مــــا اطلعــت

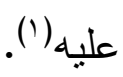
و أرجو أن يكون فى نشر هذا الديوان حافز على الاستقصاء فى دراسة هذا الثاعر ، وجمع أشنعاره و أخباره. و على هذا الديوان فى طبعته الثالثة عام 999 ام قامت هذه الدر اسة لـشعر على بن الجهم من خلال أربعة أغر اض شعرية معه لنتبين ملامح النجابة والفهم

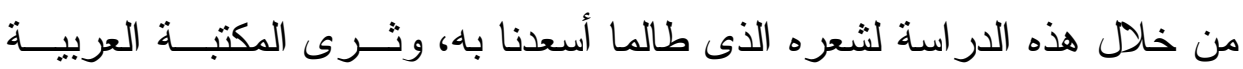
برو ائعه.

نشأ شـاعرنا "على بن الجهم" بن بدر بن الجهم بن مسعود القرشى الـسامى

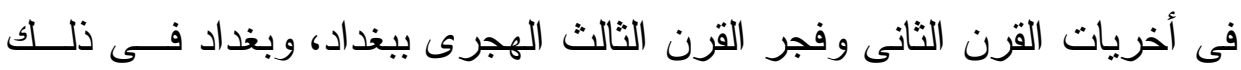
الزمن حاضرة الدنيا علماً وأدباً وحضارة، وربى فى بيت علم وفضل؛ فقد كــان

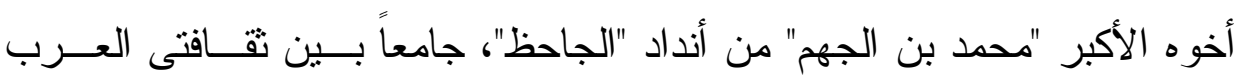

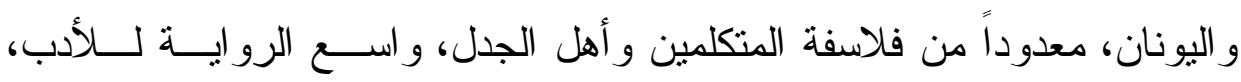

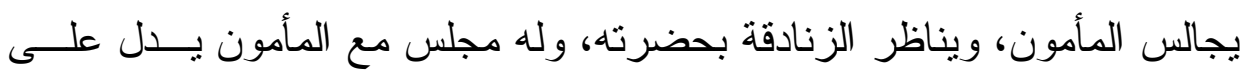
سعة رو ايته للشعر • ذكره صاحب الأغانى. وقد كان "الجاحظ" يكثر مــن ذكــره

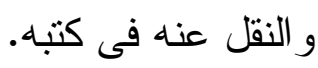

كان هذا فى الطبعة الأولى و الثانية، أما فى هذه الطبعة وهى الثالثة فقد وجدنا الــديوان

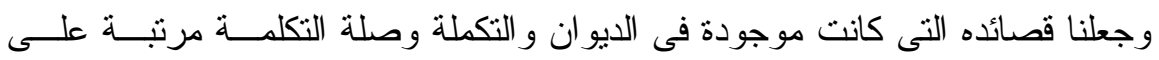

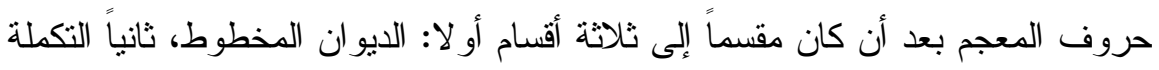

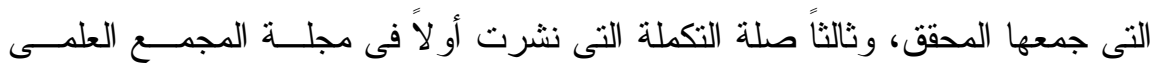

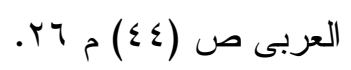


وفى هذه البيئة الز اخرة بالعلم و الأدب نشأ "على بن الجهم"، وصحب الكتب

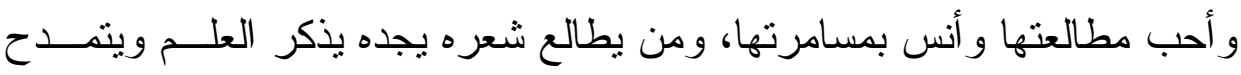
به، ويذم الجهل بأساليب مختلفة منها قوله:

إذا لم يشب رأس على الجهل لم يكن على المرء عار أن يشيب ويهرمسـا وقوله:

ما النقص إلا أن يكـون جهــولال(') لم تتقــصوه وقـــ ملكـتم ظلمـــه صحب "على بن الجهم" شعر اء بغداد، و غيرهم من الطارئين عليها، وكـــان يختلف إلى قبة الثعر اء فى المسجد الجامع ببغداد، ينشد شعره ويـسمع وينتقــــ،

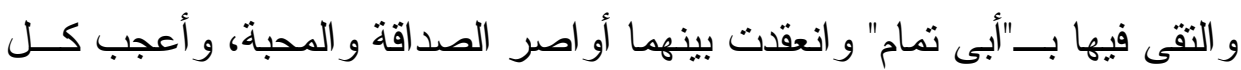

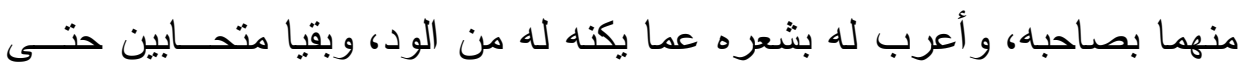

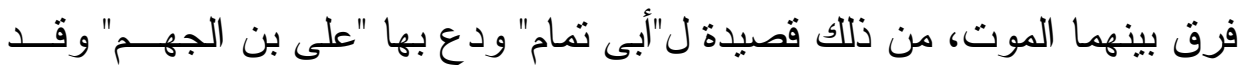

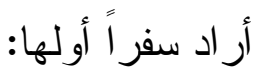

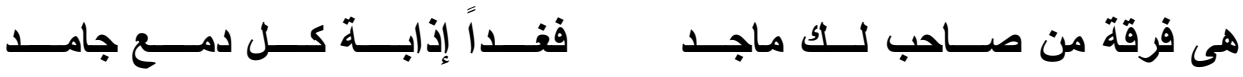

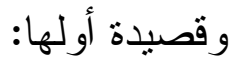

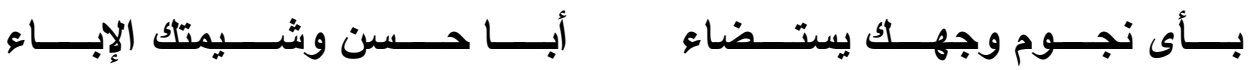
ومن شعر "على بن الجهم" فى "أبى تمام" قوله:

وعـــــ عليهـــــا نكبـــة الأيــــام غاضـــت بــــائع فطنـــة الأوهــــام

انظر : ديوان "على بن الجهم" تحقيق خليل مردم بك ص (Yr) دار صــادر، بيــروت، لبنان، سنة 997 ام. 
وغدا القريض ضئيل شخص باكيــا يــشكو رزيتــــه إلــــى الأقـــلام

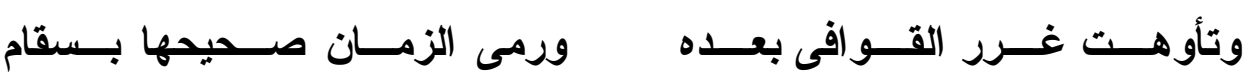

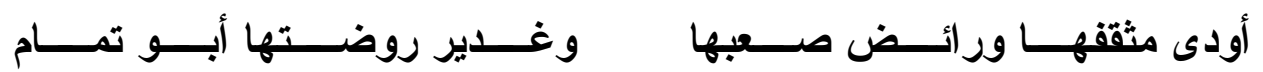
ظهرت ملامح النجابة و الفهم على شخص "على بن الجهم" منذ صغره؛ فقد طلب أبوه من شيخ الكتاب أن يحبسه يوماً؛ لأنه يثير ضجة فى البيت؛ فكتب إلى أمه:

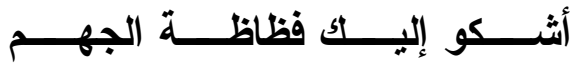

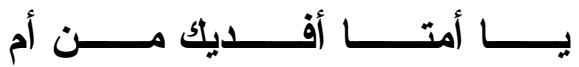

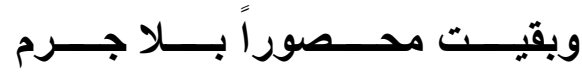

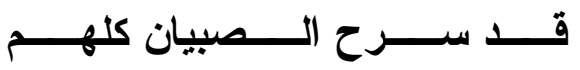
قال على: وهو أول شعر قلته وبعثت به إلى أمى؛ فأرسلت إلى أبى: "و الله لئن لم تطلقه لأخرجن حاسرة حتى أطلقه". وكتب يوماً على لوحه إلى بنت صغيرة كانت معه:

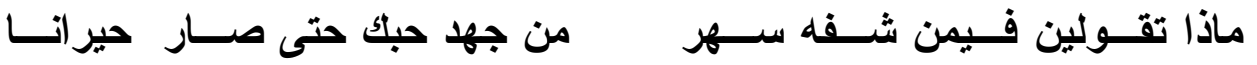
فكتبت له البنت رداً تقول فيه:

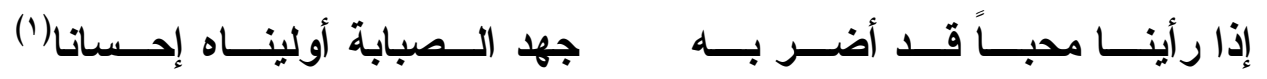
لا يقل هذا الشعر روعة عن شعر كبار شعر اء الغــزل المــشهورين فـى

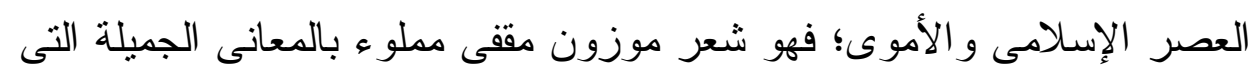

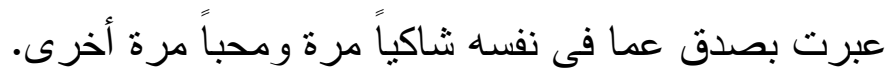


بجانب هذا جمع "على بن الجهم" بين الثقافة والفتوة، وقول الثعر و العلم بـ و أدب النفس وشرف النسب، و الثروة و الجاه. سيفه ولسانه فى الصر امة و المضاء

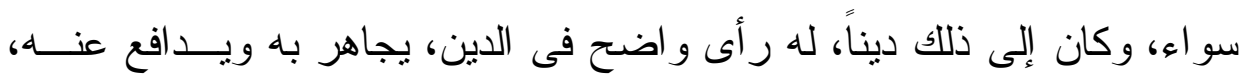
وكان يزور الإمام أحمد بن حنبل ويسأله مسائل فى القدر و الصفات، وفى شعره شو اهد كثيرة يظهر فيها أثز الكتاب و السنة (1)". قال أبو بكر الصولى: "سمعت أبا إسحاق الحربى يقول: كـــان علــى ابــن الجهم من كملة الرجال". وكان معتداً بنفسه ونسبه، حسن المحاضرة و المفاكهــة

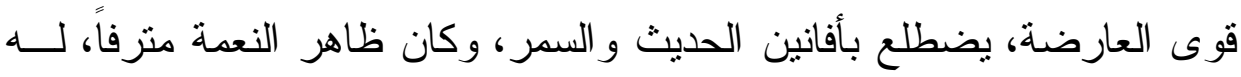
خدم و عبيد وحجاب، وفى داره عدد من حسان الإماء"(؟). فى خلافة المأمون (919 اهــ) أخذ اسم "على بن الجهم" يـشتهر بالـشـعر ، وروى الناس شعره حتى بلغ المأمون. قال "محمد بن الجهم": "دعانى المــأمون يوماً فقال: قد نبغ للك أخ يقول الثعر فأنشدنى له، فلم أذكر إلا قوله فى الكلب: Los

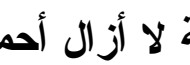

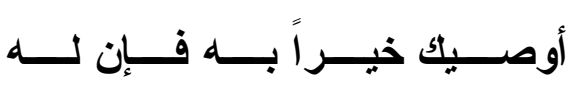

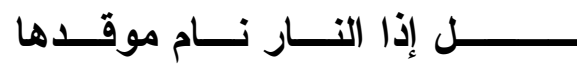
يدل ضيفى فى غسق اللا فقال المأمون: أحسن الموصى بالكلب و أمر لى بمال(). ارتحل "على بن الجهم" إلى خر اسان ثم الثغور و الجبال ومــصر و الـششام، و أقام فى كل منها مدة، و المظنون أنه بدأ أسفاره هذه فى أو اخر خلافة المأمون.

$$
\text { انظر : انظر : الديوان ص (^) السابق ص (•). }
$$




\section{Oو A}

كان "على بن الجهم" عالماً بالشعر، قال أبو بكر الصولى: "ويصحح علــم على بالثُعر ما جاء به عبد الله بن الحسين قال: قال لى البحتزى: دعانى "علــى

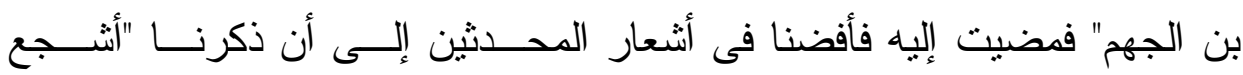

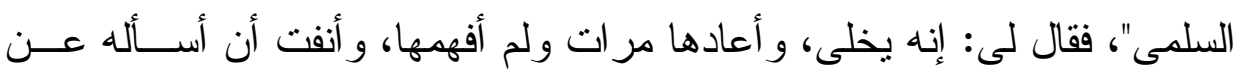
معناها، فلما انصرفت فكرت فى الكلمة، ونظرت فى شعر "أثنجع السلمى"، فـــإذا هو ربما مرت له الأبيات مغسولة ليس فيها بيت ر ائع، و إذا هو يريد هذا بعينــــ؛

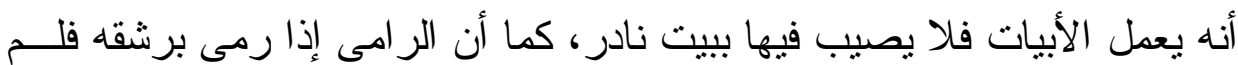
يصب فيه بشىء قيل أخلى. قال: "وكان "على بن الجهم" عالماً بالشعر" "( "). إن شاعراً يفهم ما يقع فيه نظر اؤه من أخطاء فنية تبلغ حد الإخلاء؛ أى لا

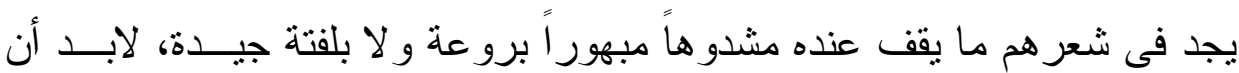
يكون حاز قصب السبق شعراً ونقداً، وأن يكون علمه بالثعر أكبر مــن شــعره

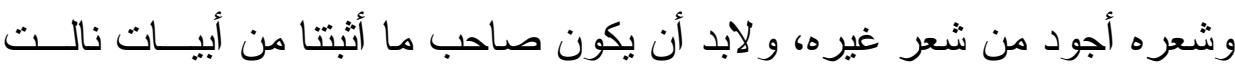

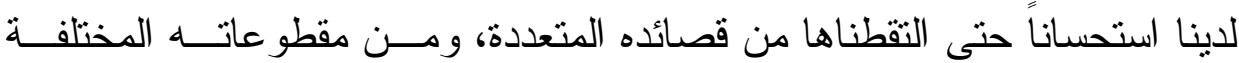
لتكون دافعاً لنا على متابعة السير خلال هذه الدراسة لشعره ولنبرز أهم ملامـــح

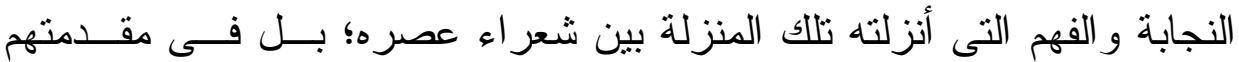
أحياناً.

لقد كان "على بن الجهم" عالماً بالشعر وفنونه قديمه ومحدثه، واسع الرواية

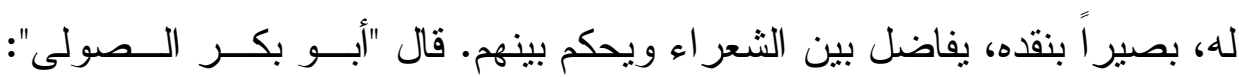
"حدنتى محمد بن موسى قال: "سمعت "على بن الجهم" ذكر "دعبلاً" فكفره ولعنه، 
وطعن على أنثياء من شعره، وقال: "كان يكذب على "أبى تمام"، ويــضع عليــه

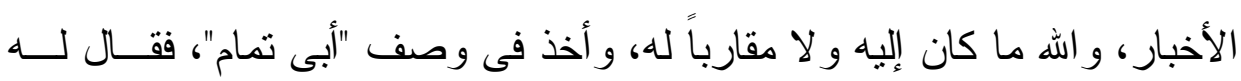
رجل: واله لو كان أبو تمام أخاك زدت على مدحك له، فقـال: إلا يكـن أخــاً بالنسب، فإنه أخ بالأدب و الدين و المودة، أما سمعت ما خاطبنى به:

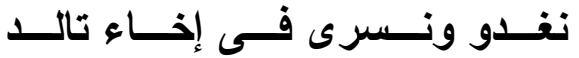

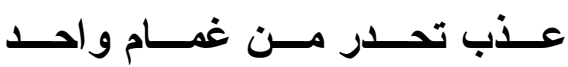

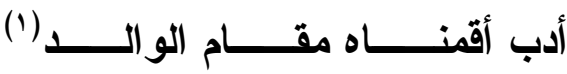

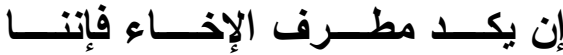
أو يختلف مــاء الوصــال فماؤنـــا أو يفتـــرق نـسب يؤلــــ بينت

أثنرنا إلى ذلك من قبل أن الذى يجمع الأدباء و الـشعر اء مهــــا اختلفــــ الأنساب وتقرقت الأصول وتعددت الآباء والأمهات هو الأدب؛ فهو الأب الـــى إذى ينتسبون جميعاً إليه.

إن من بطالع شعر "على بن الجهم" سيجده قد تعددت أبو ابه و التــى يمكـنـن تصنيفها إلى المديح و الرثاء و الفخر و الهجاء و الوصف و الغزل و الحكمة، وهنالك

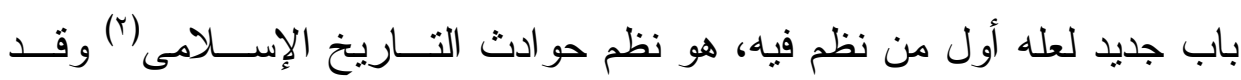
تخيرنا من هذه الأبواب أربعة هى؛ المدح و الهجاء و الفخر و الرثاء لدر استها فنياً بهدف إظهار و استخر اج ملامح النجابة والفهم التى ظهرت و لازمت الثناعر منذ صغره حتى استوى عوده وتر عرعت فروعه فى عالم الشعر و آتت أكلها ثـــاره فى كل حين فوجد الأدباء فيها متعتهم، و النقاد ضالتهم.

$$
\text { انظر : الديوان ص (rT) ( انظر) }
$$

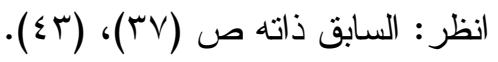


والسؤال هو: لماذا المديح و الهجاء و الفخر و الرثاء كانت محل الدر اســـة؟

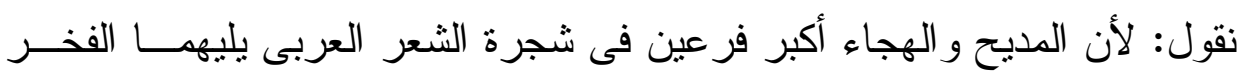
و الرثاء؛ فعلى الأربعة المعول فى الدر اسة، و على الله العون فى إتمامها.

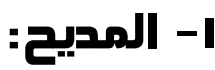

إذا كان الشعر اء منذ الثاعر الأول حتـى العـصر العباسـى - كلهــم أو بعضهم - قد أصابو ا غنى وثر اء أو أصابو ا شهرة أو نالو ا منزلة عـن طريــق الق مدح السادة و القادة الذين عاصروهم و اتصلو ا بهم ونظمو ا فيهم قصائد المــديح؛ فإن شاعرنا "على بن الجهم" لم يكن من هؤ لاء الثُعر اء؛ بل كان نسيج وحــده أو من بعض من لم ينتظر شهرة ولم يطلب غنى وثر اء؛ فقد كان نابه الــذكر غنيــاً

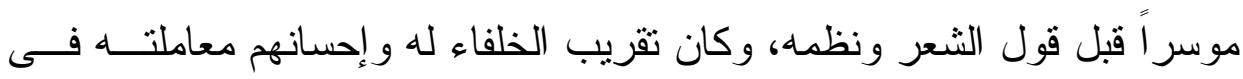
مجالسهم هو الذى دفعه إلى مدحهم؛ فكان مدحه إياهم جز اء إحسانهم إليه، فهـو

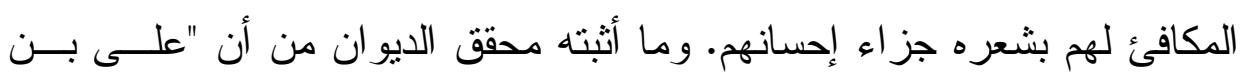
الجهم" كان من أسرة ذات ثز اء ومنزلته عالية من الثرف و الحسب حق كله؛ فقد ولى "المأمون" أباه "الجهم بن بدر" بريد اليمن وطر ازها ووولاه الثنغر، كمــا و لاه

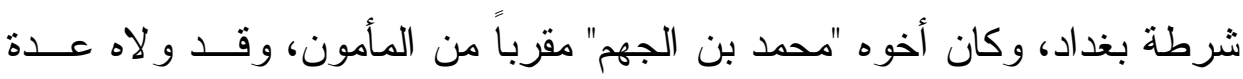

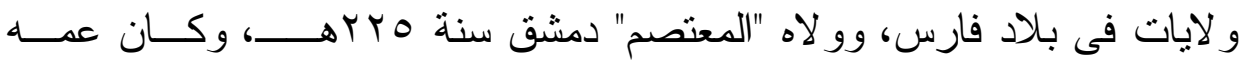
"إدريس بن بدر" من الرؤساء و الوجهاء رثاه الثناعر "أبو تماح"، وكان ابن عمـــه "عثمان بن إدريس" ممن قصدهم" أبو تمام"(').

$$
\text { انظر الديوان ص (ד، V). }
$$




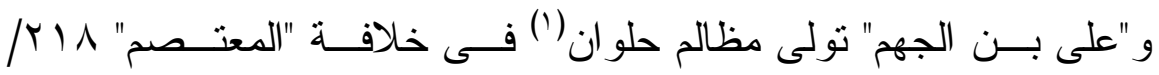

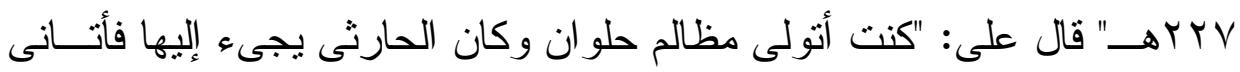
مرة وظهر كوكب الذنب فى تللك الليلة؛ فقلت:
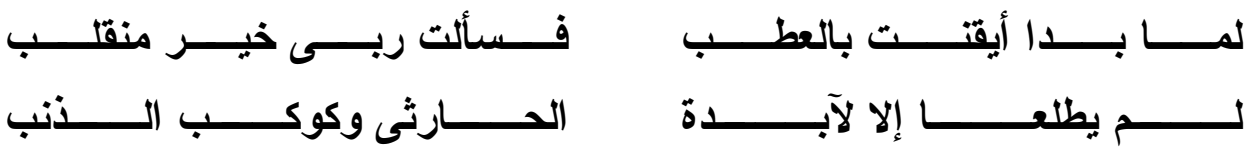

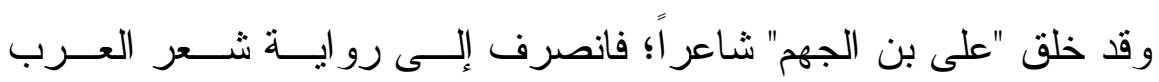
و المحدثين وصحب شعر اء بغداد وغير هم من الطارئين عليها، وكان يختلف إلى

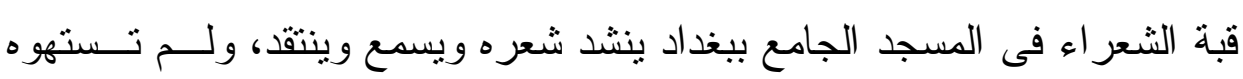
الفلسفة اليونانية كما استهوت أخاه محمداً (r). قال ابن رشيق: "قال "على بن الجهم" فى مدح "المتوكل":

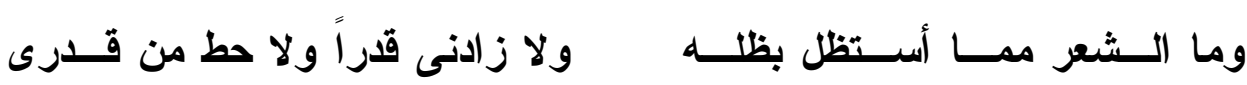

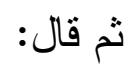

دعانى إلى ما قلت فيه من الــشعر ولكـنـن إحسـسان الخليفـــة جعفــر فذكر أنه لا يستظل بظل الشعر؛ أى لا يتكسب به، و أنه لم يزده قدراً لأنه

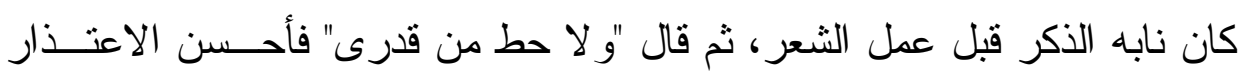

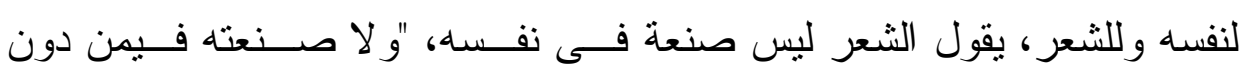

(1) حلوان من ثغور الكوفة بالعراق وهى: حلوان، و الموصل، وماسبذان، وقرقيسيا، انظر

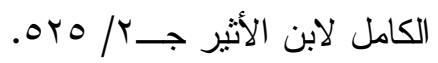

انظر : السابق ص (1'). 
الخليفة"، وما كفاه ذلك، حتى جعل نفسه بإز اء الخليفة؛ بل مكافئًاً له بشعره علــى ألـ إحسان بدأه الخليفة به، ولم يرض أن يجعل نفسه ر اغباً و لا مجتدياً"('). ومن المعروف أن الثاعر منذ العصر الجاهلى كان يرسم فــى ممدوحـــهـ

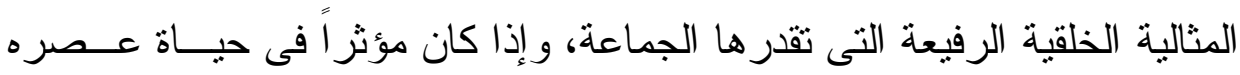

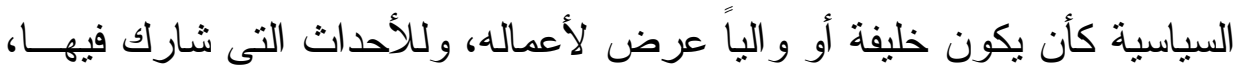

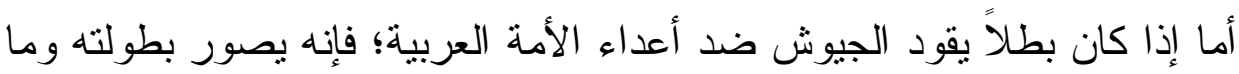
خاضها من معارك حربية.

وفى العصر العباسى نجد الشعر اء يعيدون ويبئون فــى تـصوير المثــل

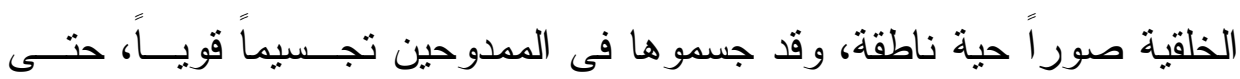

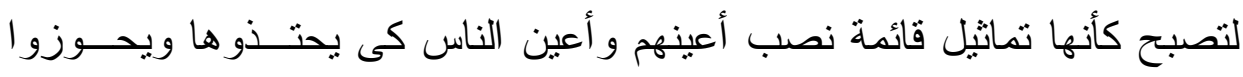
لأنفسهم مجامع الحمد و الثناء.

وقد مضى الثعر اء العباسيون فى مديح الخلفاء و الو لاة يضيفون إلى هـــهـ

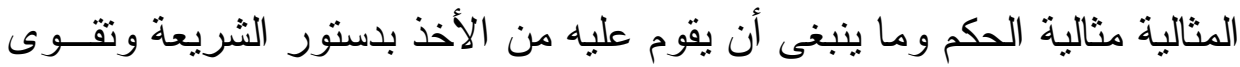

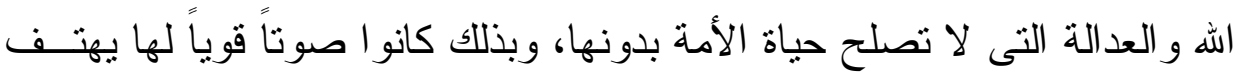

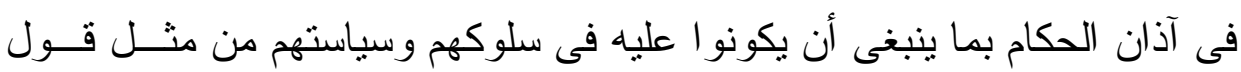
مروان بن أبى حفصة فى المهدى(r):

سـنـن التبــى: حرامهـــا وحلاههــا

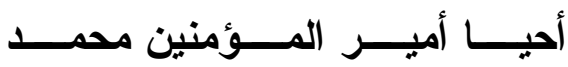

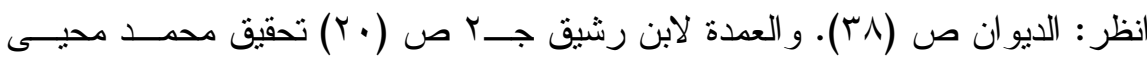

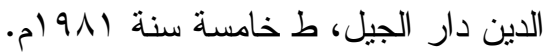

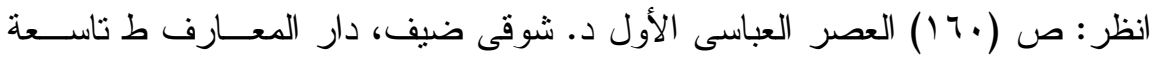




$$
\text { وقول "على بن الجهم" فى مدح "المتوكل": }
$$

بقوس رسول الله يرمــى وينــل

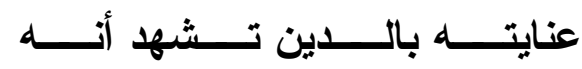
وقوله:

وقـــام بـــأمر الله والأمـــر مهــــل أعاد لنــــا الإســلام بعــــ دروســـه

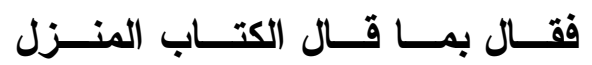

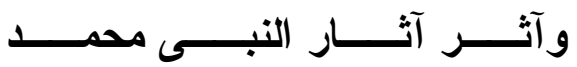
و أطفأ نير اناً علــى الــدين نـشعل وألـــف بــين المـسـلمين بيمنـــهـ و لا نغفل ما سجلته صحف المديح فى هذا العصر الذى نشأ وتر عرع فيـــ

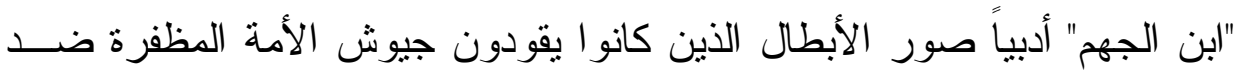
أعدائها، ومن هؤلاء "آل مصعب" وهم بنو عبد الله ابن طاهر بن الحسين بــن الحسئ مصعب الخز اعى أمير خر اسان و ابنه طاهر ابن عبد الله ولى خر اســان بعــده، و ابنه عبيد الله بن عبد الله ولى شرطة بغداد؛ فقد مدحهم "ابن الجهم" طى قصيدة رثى بها "المتوكل" بعد مقتله، يقول:

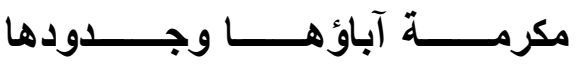

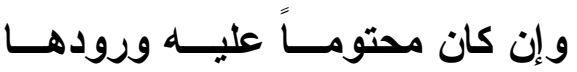

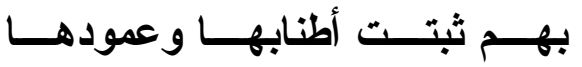

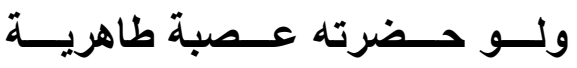

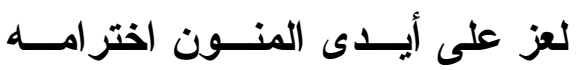

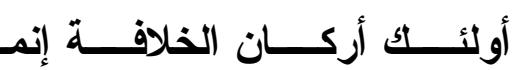
ومما سجل من مديح فى ديو انه نجد ونعلم أنه لم يمدح إلا خليفة؛ فقد مدح

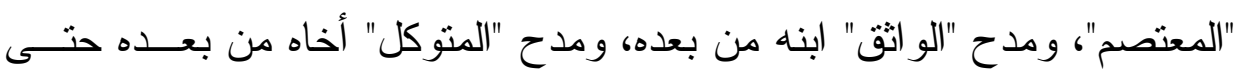
أصابته الفتتة التى حبس بسببها. وكانت المدحة قديماً تشنتل على مقدمات تصف الأطلال وعهــود الهـوى بها، وما يلبث الثاعر أن يستطرد إلى وصف الصحر اء ناعتاً ما يركبه من بعير 
أو فرس وما ير اه فيها من حيوان وحثى، وقد يعرض لوصف مسـشه صــيد،

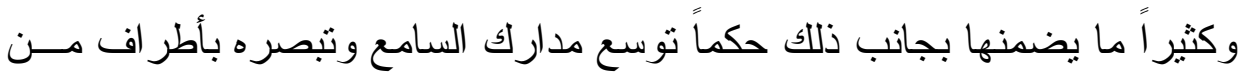
سنن الحياة، وكل ذلك استبقاه الثـاعر العباسى؛ ولكن مع إضـــافات تعبــر عــن الذخائر العقلية و الخيالية للشاعر العباسى، منل قول مسلم بن الوليد:

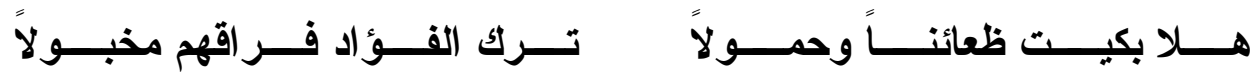

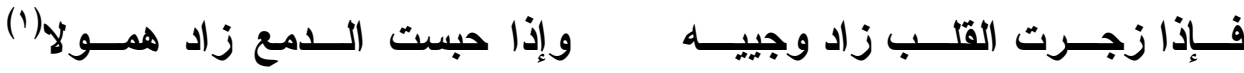

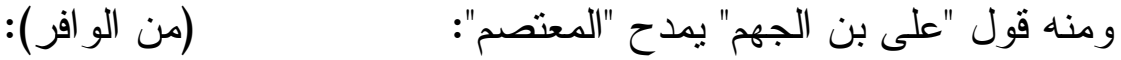

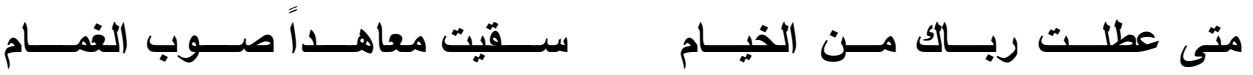

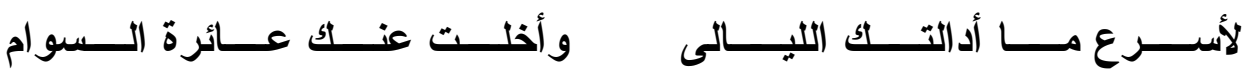

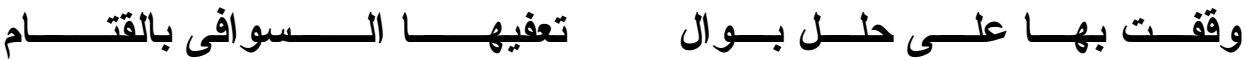

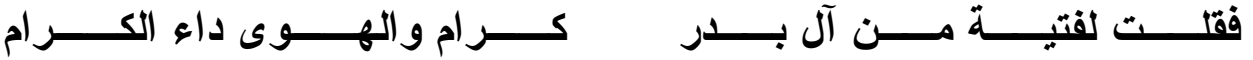

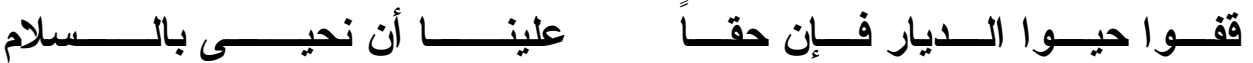

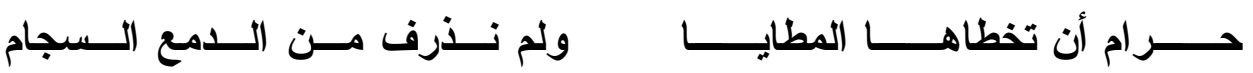

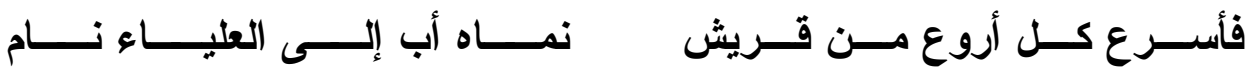

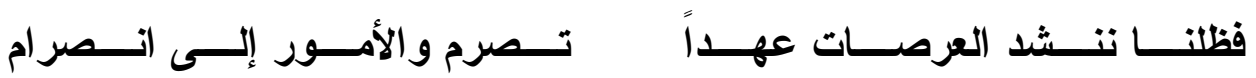

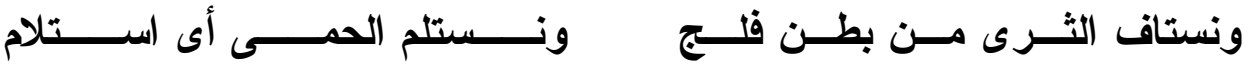
إلــــى أن غاضــــت العبـــرات إلا

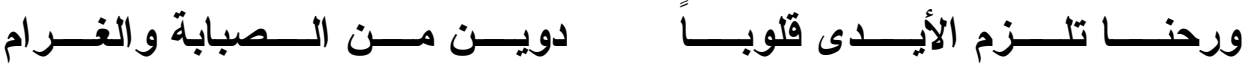

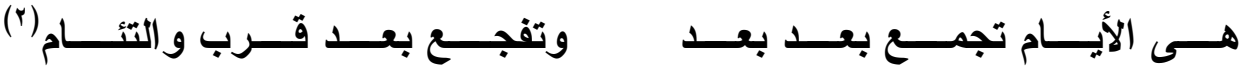


وقد نعجب من استبقاء هؤلاء الثتعر اء المتحــضـرين لعناصــر الأطــلهل

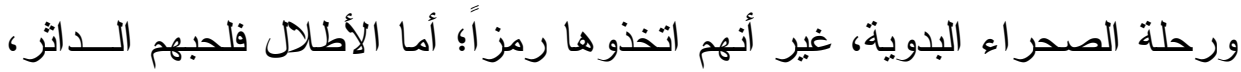

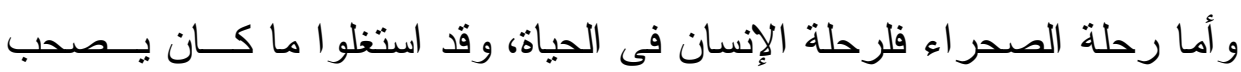
الأطلال من حنين لذكريات حبهم ومعاهده لا يز ال يتزقــرق فــى أثـــعار هم ('). ونجد ذلك عند "على بن الجهم"؛ فقد انتقل من وصف الأطلال وتحيتها بالـسـلام

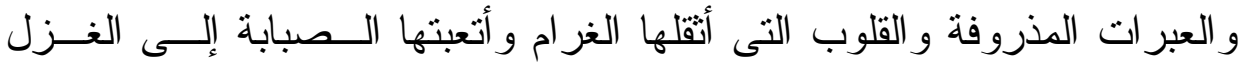
و الحديث عن الهوى. ثم ينتقل الثاعر إلى مدح الخليفة؛ فيقول:

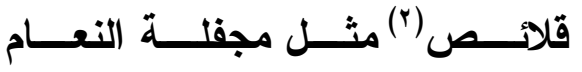
إلى اللبــات مــن جعــ اللغــام(") وقـــور الرحسـل طيــــاش الـــــــام

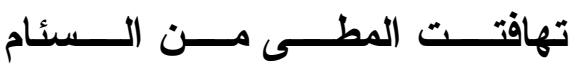

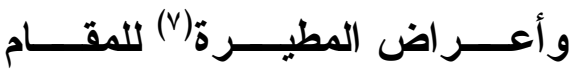
قــــــان الليـــل بالليـــل التمـــــام

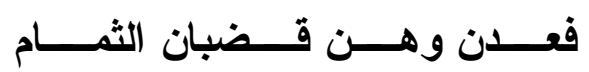

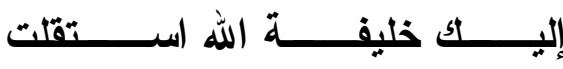
تر اهــــــــا كالــــــــر اة معمدــــــــات

(๕)

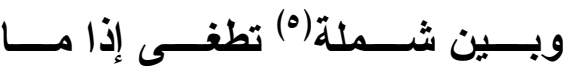

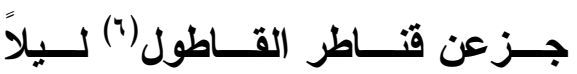
فعجن بهـــا وقــــ أنــضـى طلاهـــا

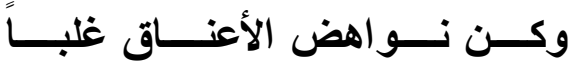

$$
\begin{aligned}
& \text { انظر : العصر العباسى الأول ص (ب7 (1). مرجع سابق. } \\
& \text { قلائص: جمع قلوص؛ الإبل الثابة. } \\
& \text { اللغام: زبد أفو اه الإبل. } \\
& \text { النجى: البعير السريع. ربد اهن: } \\
& \text { ناقة شملة: أى سريعة. } \\
& \text { القاطول: نهر عند سامر اء مقطوع من دجله. } \\
& \text { المطيرة: قرية من نو احى سامر اء. }
\end{aligned}
$$




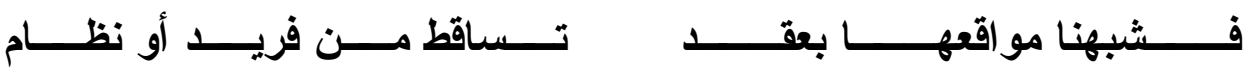
وصف رحلته إلى "المعتصم" على الجمال و النوق تماماً كما كــان يــصنع الثـاعر الجاهلى فقد عبرت به وبرفاقه القاطول فى الليل حتى قرية المطيرة مــن نو احى سامر اء، وقد سارت سيراً طويلاً حتى وصلت إليك فمكنتى من مدحكى على حد قوله -؛ ثم ينتقل من المقدمة إلى الغرض الرئيس محسناً التخلص فـى فئى قوله:

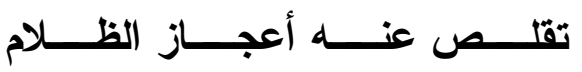

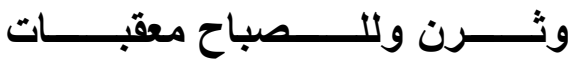
أضـــوء الـــبح أم وجـــه الإمـــام

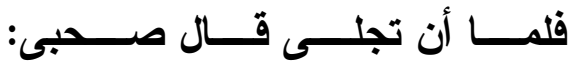

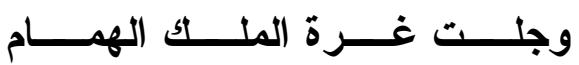

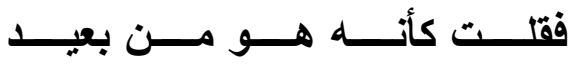
دواعـــى الـــود و الهمهــم الــسوامى

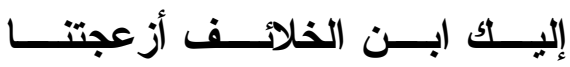

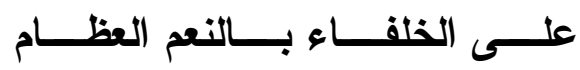

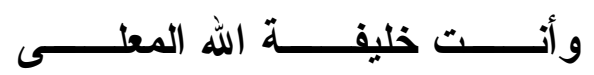

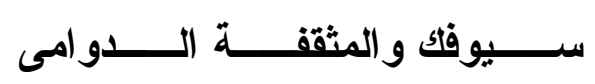

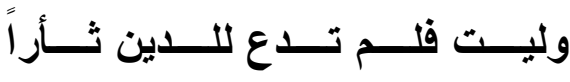

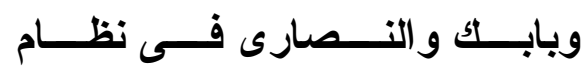
نـــبت المازيــار علـــى ســـوق عزيـــز النــصر ممنـــوع المـــرام

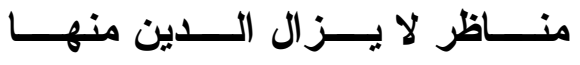

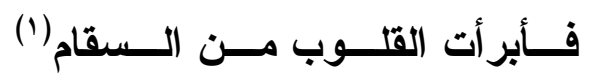

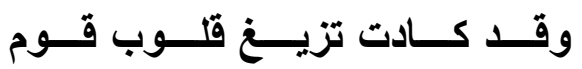
وصفه بأن الله فضله على الخلفاء بجمال الخلق كوضـاءة الوجــهـه وبــالنعم العظام؛ فقد وفقه للأخذ بثأر الدين من أعدائه الذين أر ادو ا طمس معالمـــه، فقــام بردهم بسيوفه ورماحه المشرعة إلى حظيرة الدين، ومن تجبر قصمه وقتله ثـــ

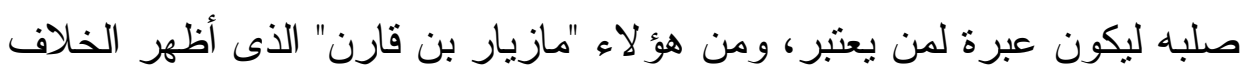

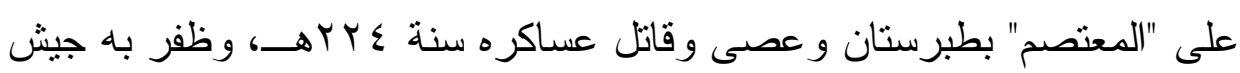

$$
\text { انظر : السابق ص (r. (Y) ( ) }
$$


الخليفة و أتى به إلى "المعتصم" بسامر اء فأمر بقتله وصلبه إلــى جانــب "بابــك

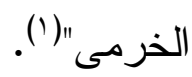
و لا ينسى "على بن الجهم" أن يذكرنا بفتح "المعتصم" لعمورية كمـــا صــنـع كثير من الشعر اء فيقول:

بــوادر مـــن عزيــز ذَى انتقـــام

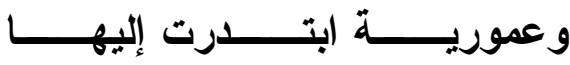

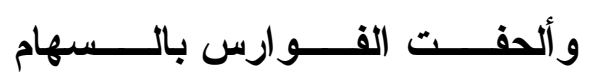

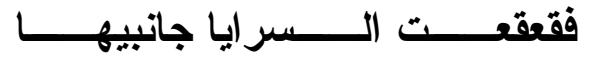

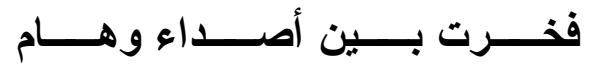

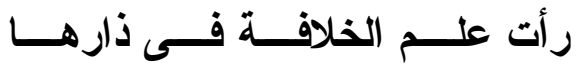
عــن الـــداعى إلـــى دار الــسـلام وجمع الزط حين عمــوا وصــموا

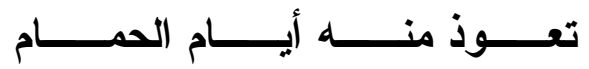

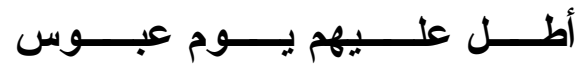
مثال آخر يضاف إلى بطو لات الخليفة يشدو بـه الثناعر ليسمع الخلق فـى

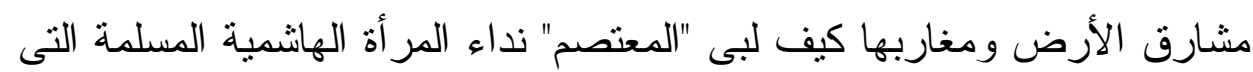
صاحت وهى أسيرة فى أيدى الروم: "و امعتصماه" فقال: لبيك وسار إلى أحسـصن ألى و أمنع بلاد الروم بجيوشه وسر اياه فقتحها ورفرف عليها علم الخلافة الإسلامية، وفى ذات الوقت تخرج جماعة "الزط" الذين بلغ عددهم ثلاثثين ألفاً وكان رئيسهم

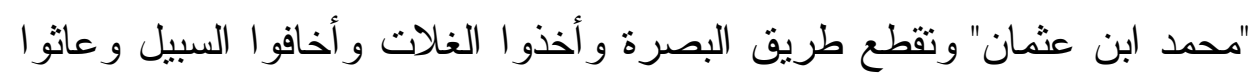
فوجه إليهم "المعتصم" لحربهم "عجيف بن عنسبة" سنة 9 1 بهـ فظفر بهم ونقلهم

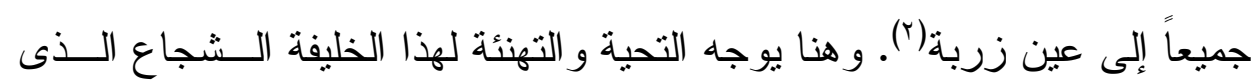

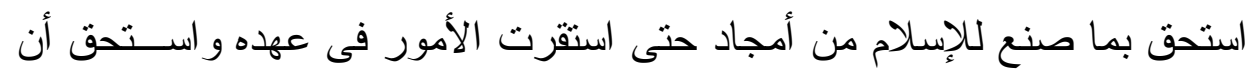

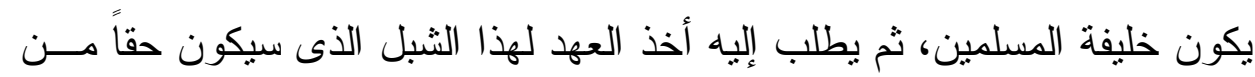

$$
\text { انظر : الديوان ص (^ • ( إ). }
$$


أبيه الأسد كما يقولون "الو اثق" و اسمه هارون وكنيته أبو إسحاق؛ فإمام المسلمين هو من يغضب لدين الله، ويعمل على استقر ار الأمة ويدافع عن أوطانها؛ يقول:

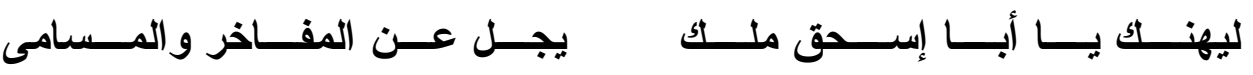

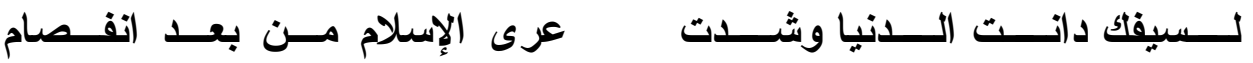

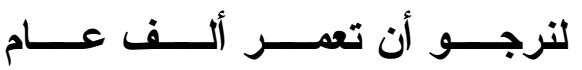

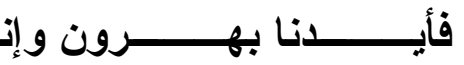

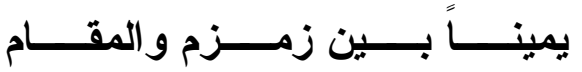

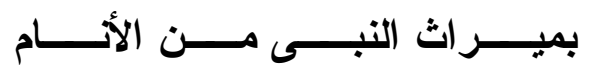

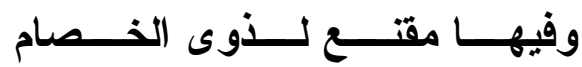
صـــــو ادع بــــالحلال وبـــــالحر ام

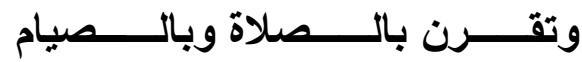

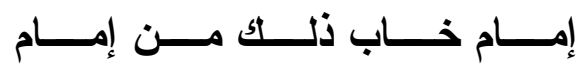
مــن الأتــــرأك مــشرعة الــسههام

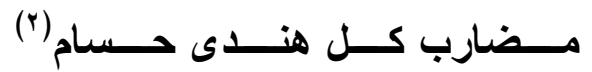

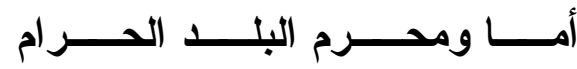

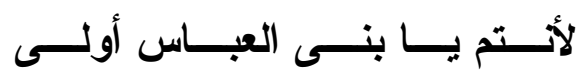

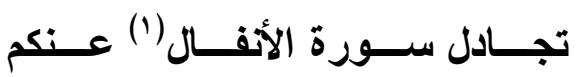
وآثتـــــار النبــــــى ومـــــــندات

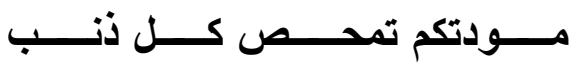
ورافضة تقــول بــشب رضــوى

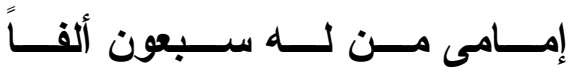

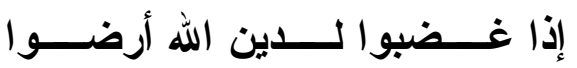
وفى خلافة "الو اثق" نجد أن "على بن الجهم" يحضر مجالسه ثم لما بويــع "الو اثث" بالخلافة نجده يقول:

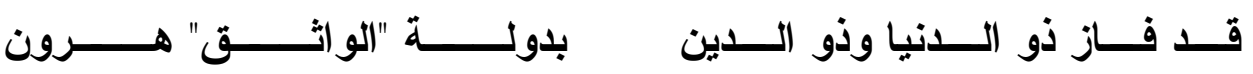

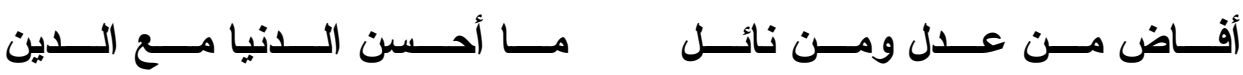

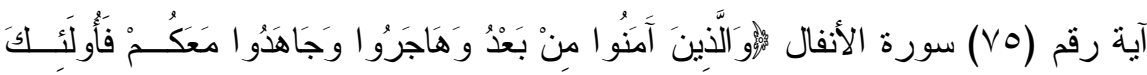

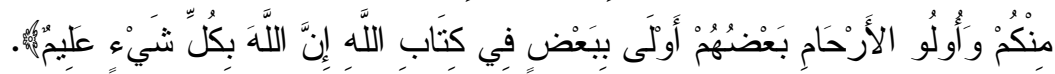

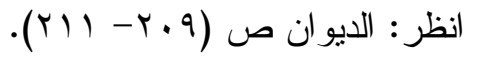




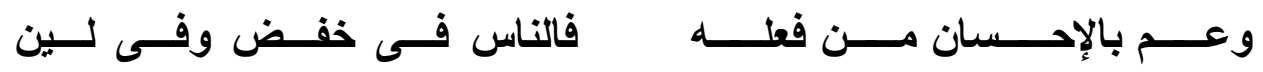

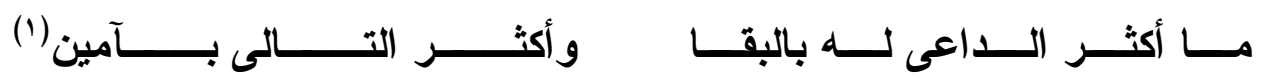
هنأه بالخلافة لما آلت إليه بعد أبيه "المعتصم"، ومدحه بصفات منها العـدل و الكرم فعدله استقرت به البلاد وكرمه عم رعيته؛ فاجتمعت لهم الدنيا مع الــدين فاستحق أن يدعو له الناس بطول العمر ويؤمنو ا على ذلك موقنين بالإجابة.

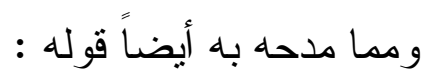

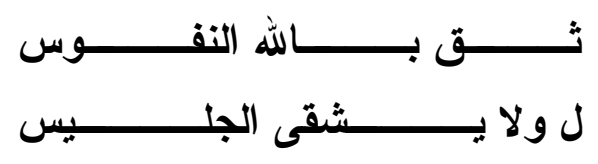

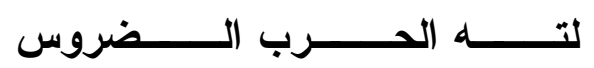

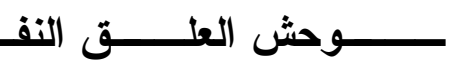

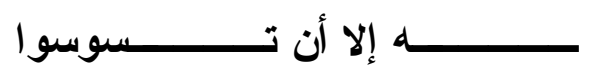

(r)

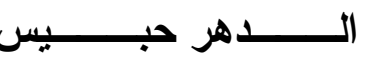

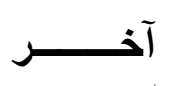
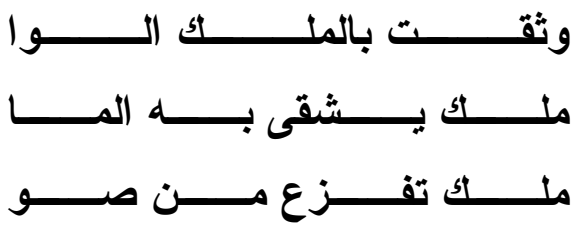
أنــس هس الــسيف بــــه واستـ

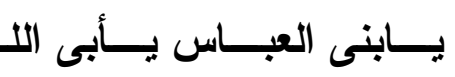

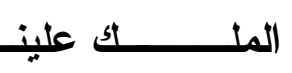
مدحه هنا أيضاً بالكرم و الثجاعة حتى وثقت به النفوس وتعلقت به؛ فهـو من سلالة هؤلاء القوم الكر ام الثجعان بنى العباس الذين هم أحق الناس بالخلافة وسياسة المسلمين، ويأبى الله أن بحكم غير هم فالملك لهم طول الدهر لا لغير هم. ومن مدحه "الو اثق" أيضاً قوله:

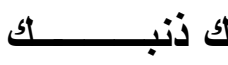

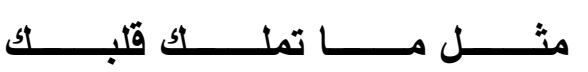

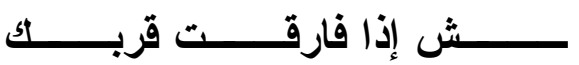
لغقرن ب
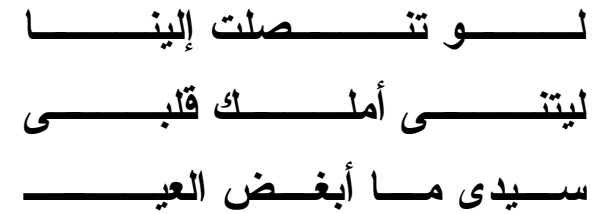

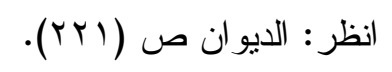

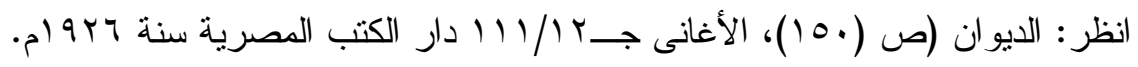




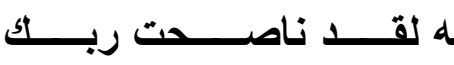

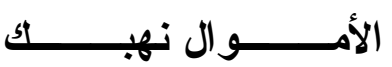

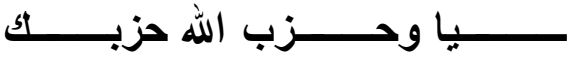

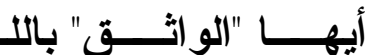

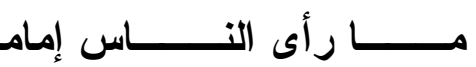

أصــــبحت حجت بـ العلا

مدحه بالكرم متمنياً أن يكون منته كريماً، و أن يبقى بجو اره دائمـاً؛ يــرى

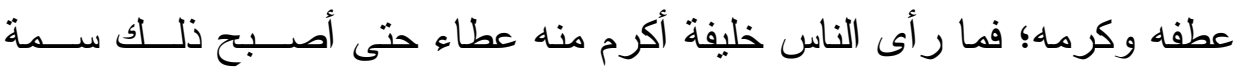
مميزة له وعلامة يعرف بها وصار حزب الله حزبه، وهذه الأبيات وردت فـى ورى الأغانى، وهى مما يتغنى به (1).

وهى كلها مما يشبه الأناشيد قليلة عدد الأبيات قصيرة الأوزان لا تدل فـى معظمها على ارتياح و انشر اح صدر ، ولعل مرد ذللك لثدة "الو اثتق" علــى أهــلـ الحديث، وفى هذه المدة أعلن "على بن الجهم" كر هه لوزير "الو اثق" "محمد بــن عبد الملك الزيات"؛ فهجاه أقبح هجاء، ولم يخش صولته و لا جبروته (؟). و هنا نصل إلى خلافة "المتوكل"؛ فنجد "على بن الجهم" يلتقى بخليفة أظهــر

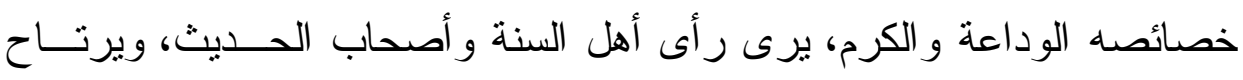
للشعر اء ويؤثز مجالسة الأدباء، وهذا غاية ما يتمناه؛ وفى ذلك يقول:

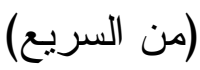

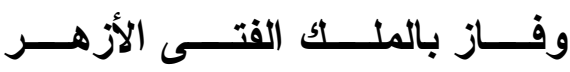

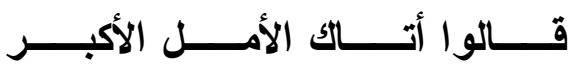

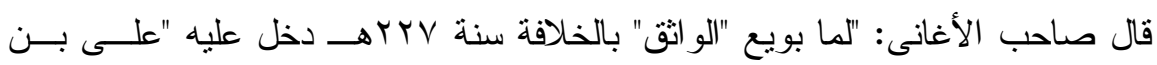

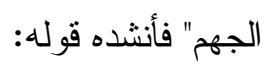

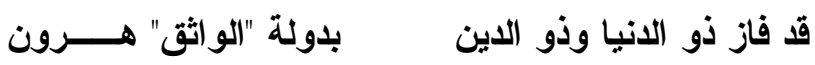

و أنشده أيضاً: وتقت بالملك "الو اثق".. فوصله "الو اثق" صلة سنية، وغنى المغنون بهذين الثعرين.

$$
\text { انظر : الديوان ص (r) ( ) ( ). }
$$


فقلـــــت قــــــــــــام إذاً "جعفـــــر

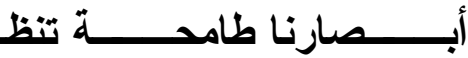

مــن كــان تـــأميلاً لـــهـ يــسهر

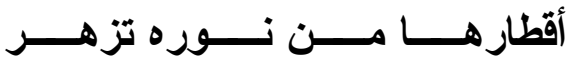

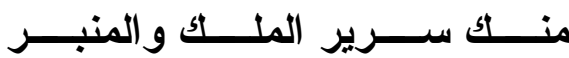

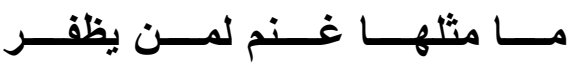

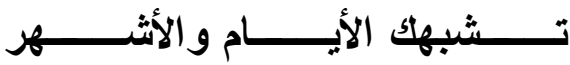

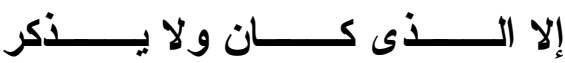

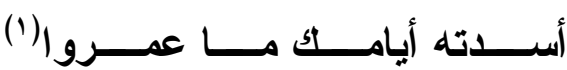

و اكتـــست الـــــنيا جمــــالاً بـــــه

ذاتك الـــــى كانــــــ إلــــى ملكـــــه

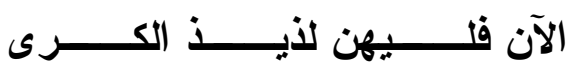

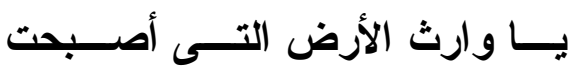

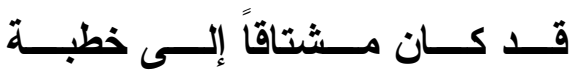

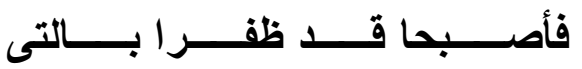

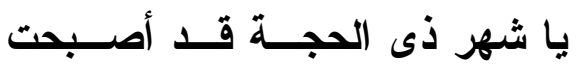

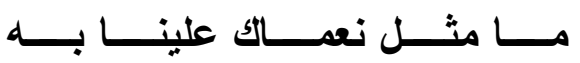

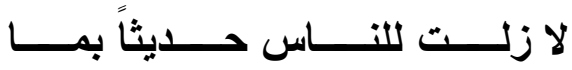

مدح "المتوكل" بما ر آه فيه من وسامة و ما لمسه فيــهـهـ مــن كـــرم أخــلاق

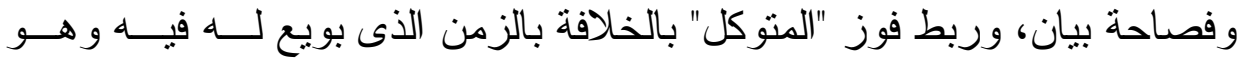

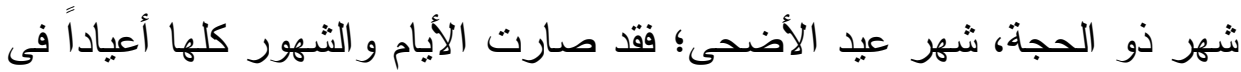

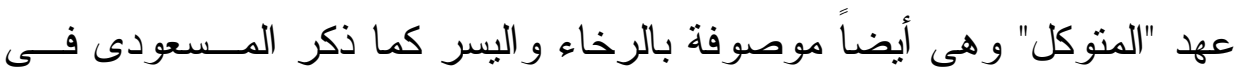

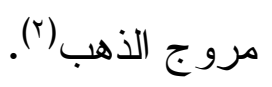

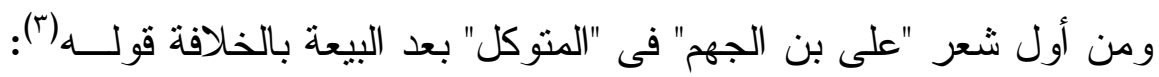

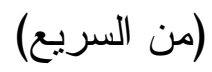

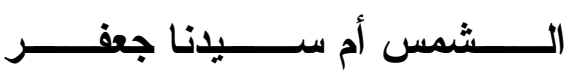

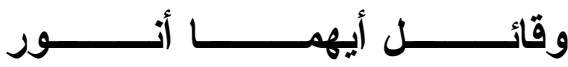

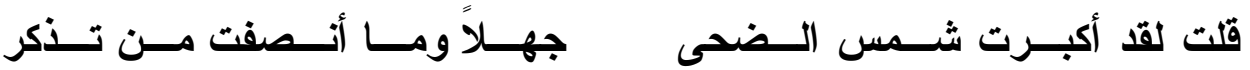

$$
\begin{aligned}
& \text { انظر : السابق ص (TY Y I). } \\
& \text { انظر : السابق ص (T؟) } \\
& \text { انظر : السابق ص (I rV) }
\end{aligned}
$$




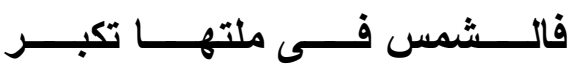

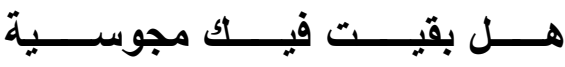

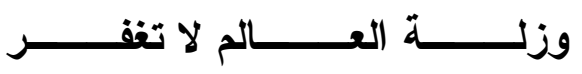

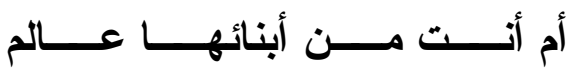

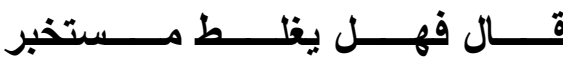

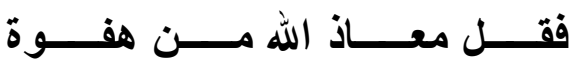
رد على من يسوى بين الخليفة نور الله فى أرضه وبين شــمس الــضحى

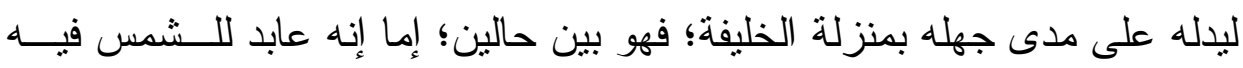
مجوسية، أو أخطأ فى هذا، فما عليه إلا أن يعود مستغفراً من زلته، وحتى تزول لئه حيرة صديقه وضح له خطأه قائلاً:

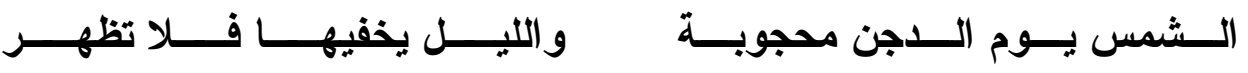
فهـــى علــى الحـــالين مملوكـــة

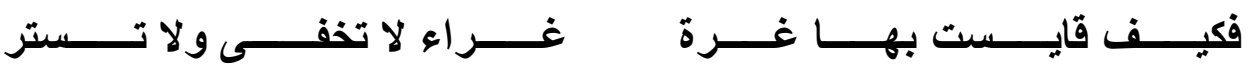

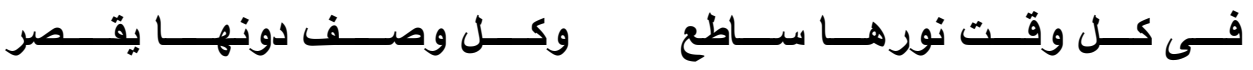
بين له بالدليل الحسى المرئى الفرق بين حال الثمس التى يحجبهــــا الغــيم ويخفيها الليل وبين نور الخليفة الذى لا يحجب، و الثمس بهذا مملوكة و الخليفــة يملك الرعية و لا يملكه أحد. يعود صديقه منسائلاً؛ يقول ('):

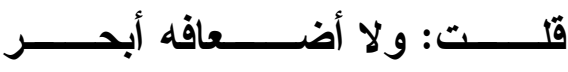

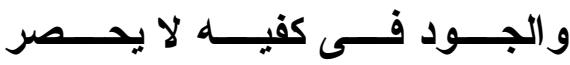

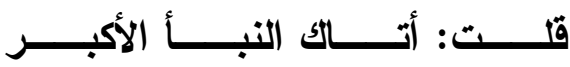
يخــــبط فيهــــــا المقبـــل المـــــبر

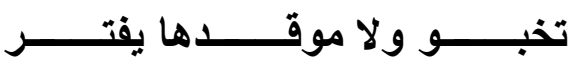
قــال وأيسـن البحسـر مــن جـوده

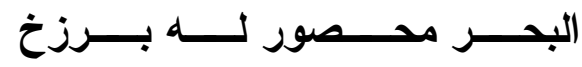

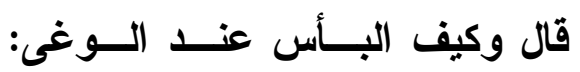

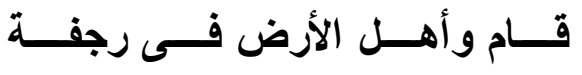

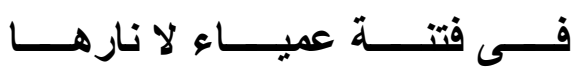
انظر : الديوان ص (I TV). 
أيــــى ســبا موعــــها المحــشر

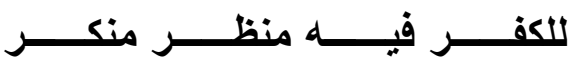

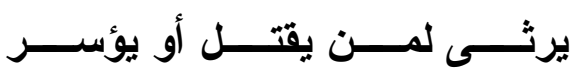

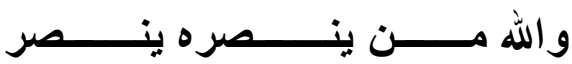

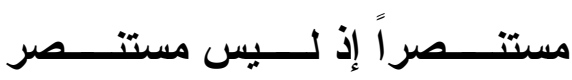

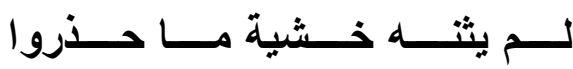

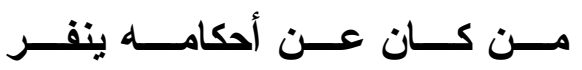

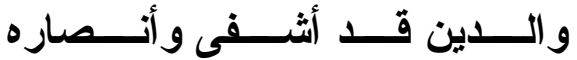

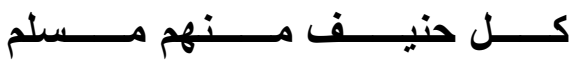

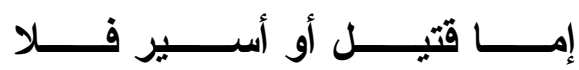

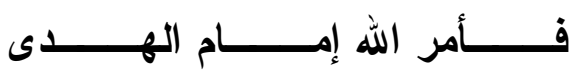

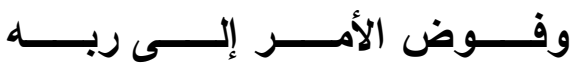

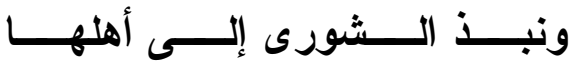

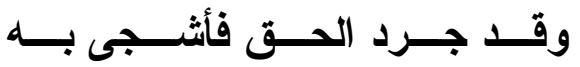

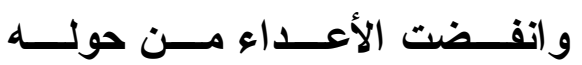

فى هذه الأبيات قص علينا وعلى من سألله عن شجاعة الخليفة ما كان؛ فقد عمت الفتتة أرض المسلمين عندما كثر الملاحدة و الزنادقة و الر افضة و النصارى

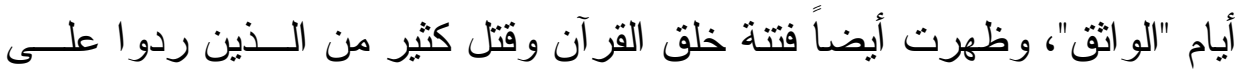

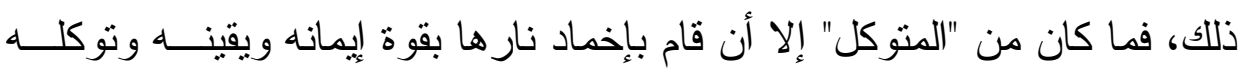

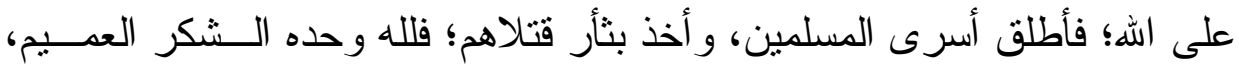
و هذا كله يدل على شجاعته فى الحق؛ فبها حقق ما يريد.

ثم يسوق الشاعر ما حل بإبليس و أصحابه بعد ما صنع الخليفة؛ فيقول:

حـل بنـــا مــا لــم نــزل نحــذر

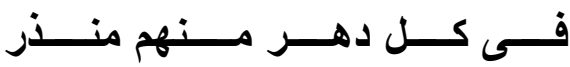

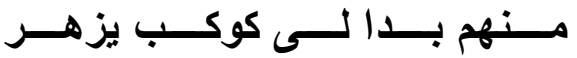

يلهــــى ولا الــــنيا التـــى تعــــر

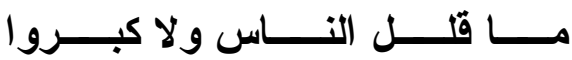

أن أظهروا الشرك كمــا أضــمروا قـــرة مــن يقـــ ومــن يقـــر

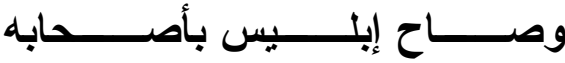

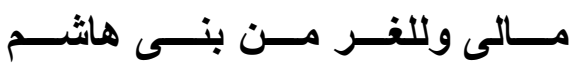

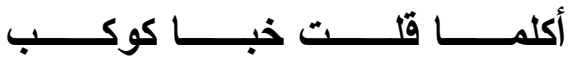
لـــم يلهـــه عنــى الــشباب الــــى

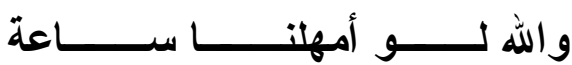

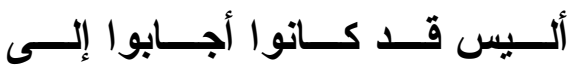

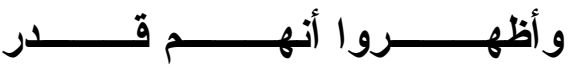




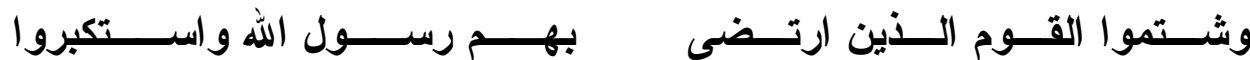

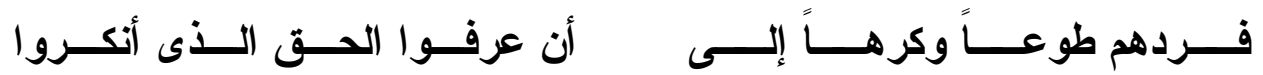

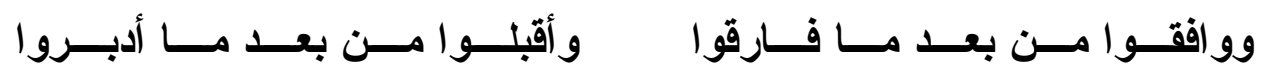
هذا حديث إبليس ساقه الثاعر ليقنع صديقه بشجاعة الخليفة، ومدى حسرة إيليس و أصحابه بسبب ما وقع عليهم كالصاعقة بعد أن رد الخليفة النـاس إلــى الطريق الصحيح و السبيل الهادية بعد أن عاشو ا في الفتتة فاكتو ا بنار ها زمنــاً، ولو لم يفعل لظل الناس فى ضلال مبين كما يريد إبليس اللعين ('). و هنا يتوجه بالتحية و التهنئة لمن بستحقها وهو الخليفة مثثياً عليه بما صنع

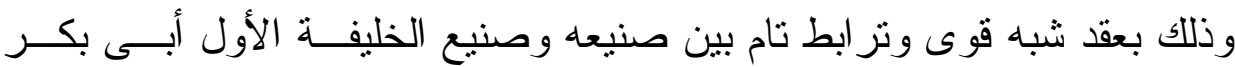

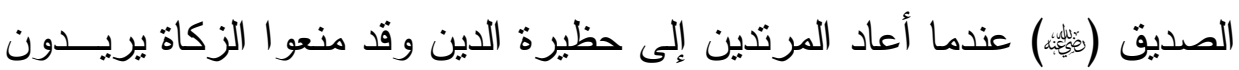
إبطال ركن من أركان الإسلام وهم لم يكفرو ا؛ فيقول:

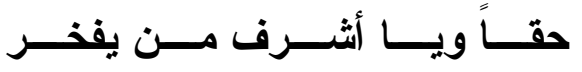

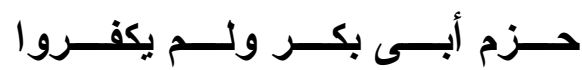

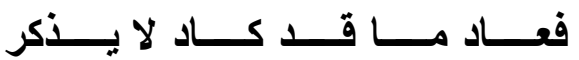
مسن معسشر مســا مسـثهم معسشر بـسطع منهــــا المـــك و العنبـــر

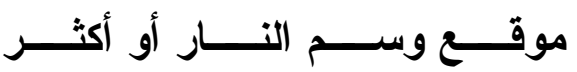
يــا أعظـــم النـــاس علـــى مـسلم

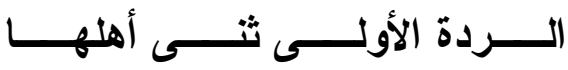

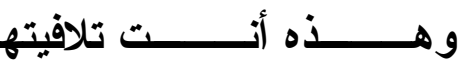

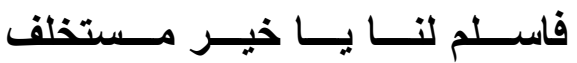
واســـمع إلــــى غــــراء ســــنية

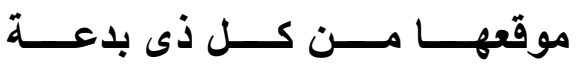

قال المرزبانى فى الموشح صهء؟ : "لما أنثد "على بن الجهم" "المتوكل" قصيدته التى

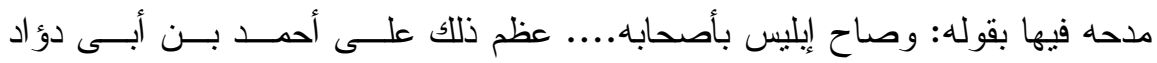

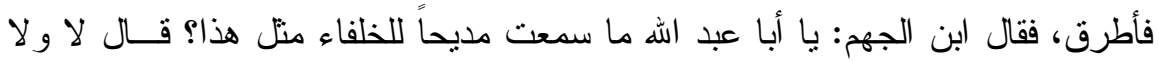

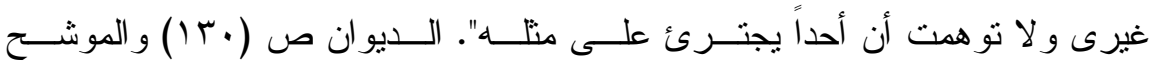

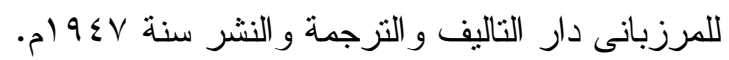


دعا له بالسلامة وطول العمر؛ فهو خير خليفة لأنه من أثـــرف النــاس،

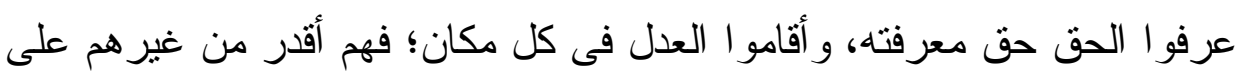
سياسة المسلمين، و هذه التحية من خلال قصيدة غر اء سنية حملت مـــدح خيــر المستخلفين وكانت فى ذات الوقت نار اً على صاحب كل بدعة يرفض ذلك.

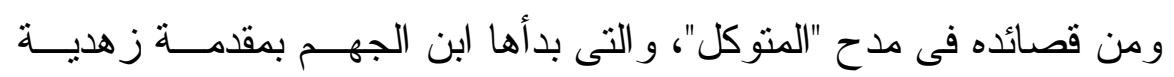
قصبدة: (هى النفس ما حملتها تتحمل)؛ وفيها يقول ('):

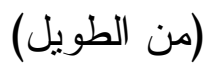

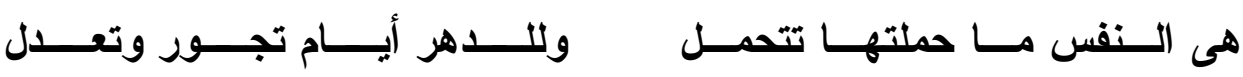

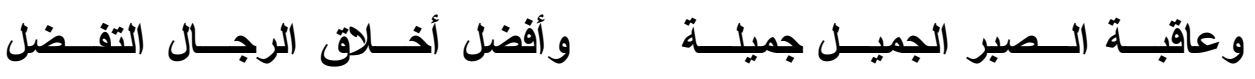

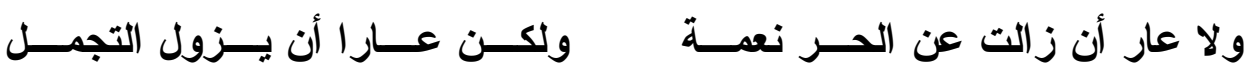
وبعد هذه المقدمة يتخلص إلى المدح وكأنه يريد أن يضرب لنا مثناً تطبيقياً و عملياً على من تتطبق عليه وتجتمع فيه كل هذه الخصال؛ إنه جعفر "المتوكل؛؛ يقول الثـاعر : n

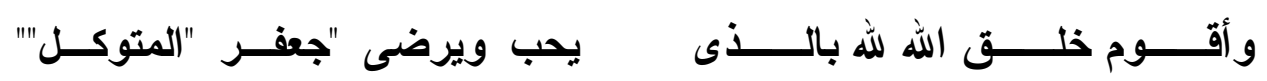

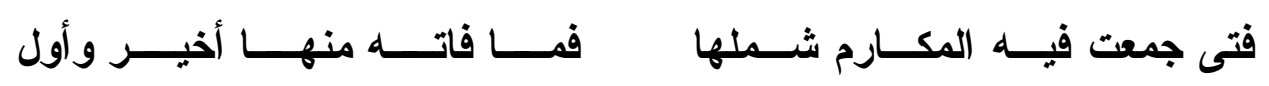

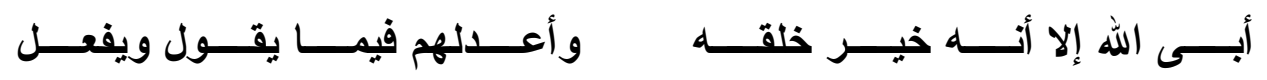
يقول:

وقة بــام بــأمر الله والأمـــر مهـــل أعاد لنــــا الإســلام بعــــ دروســهـ

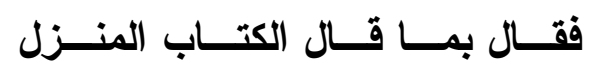

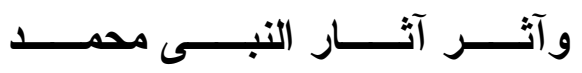


وألـــف بــين المـسـلمين بيمنــه وأطفأ نيراناً علــى الــدين تـشعل يعاقــب تأديبــاً ويعفــو تطـــولا ويجزى على الحسنى ويعطى فيجزل

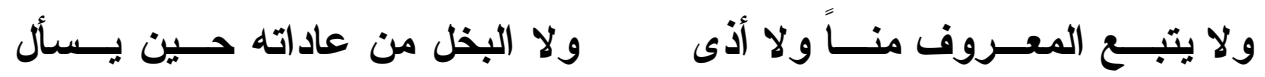
ثم يضيف إلى كل ما سبق ما يدل على نفاذ بصيرته؛ فهو يرشـــد ويهـدى رفاقه إلى خير الآر اء وأحكمها، و لا عجب فى هذا فهو معتصمى الخلق لـسيفه وقناته رونق، و عليه بهاء حين يروح ويجىء، وهو الثجاع الذى يحمـى حمــاه ويصون أمته، وهو الكريم الذى يعم نداه كل الناس؛ يقول:

عليه بهــاء حـين يبـدو ويقبـلـل ومعتصمى الخلق للـسيف والقن

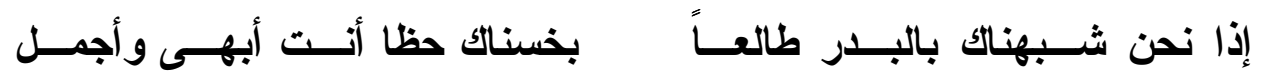

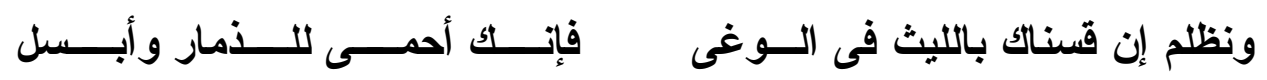

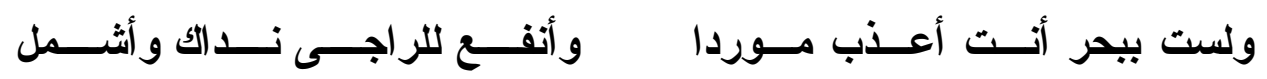

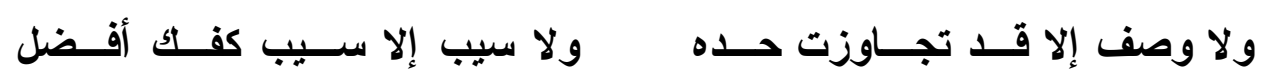

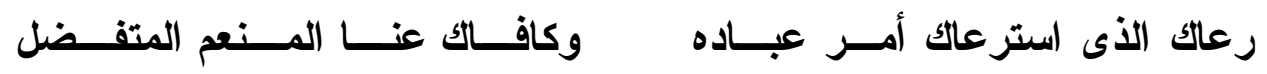
إنه أجمل من البدر حسناً وبهاءً، و أكرم من البحر مدداً وعطاءً، ثــم هـــ

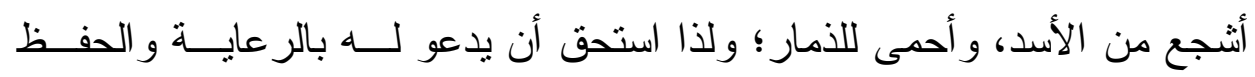
و الجز اء الحسن جز اء ما صنع لأمته. وقد أكثر الثـاعر "على بن الجهم" من مدح "المتوكل" فى المدة التى قربــــ فيها منه، و اتخذه جليساً ونديماً، وكان برسله فى حاجاته، ويفضى إليه بأســر اره

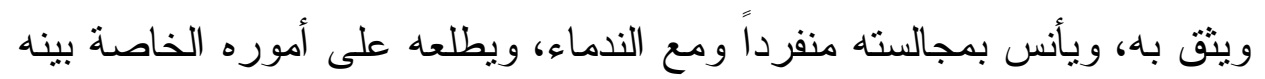

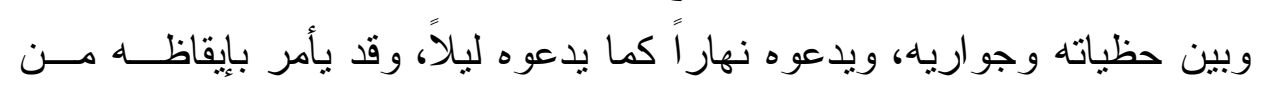
نومه ليبوح إليه بشىء من ذات نفسه. 
وكان "على بن الجهم" يتعالى على ندماء "المتوكل" وير اهم دونـــه، فــاتفقو ا

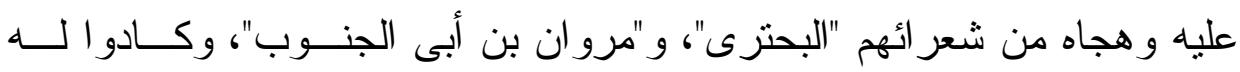

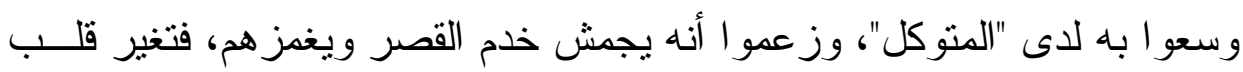

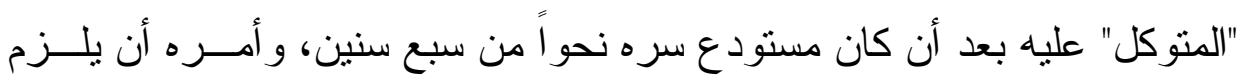
دار ه، فقعل و انقطع.

ولكن الندماء لم يققو اعند هذا الحد، فزعموا أنه كثير الطعن على الخليفــة

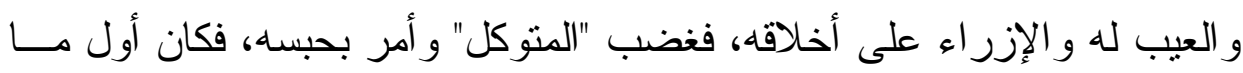
قال فى الحبس قصيدة كتب بها إلى أخيه ليوصلها إلى الخليفة أولهاب(')

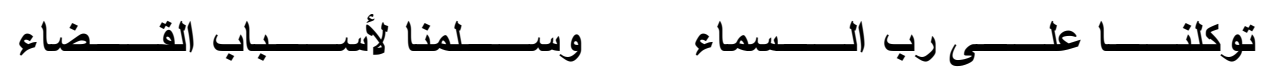
ويظهر فيها تجلداً ويهجو خصومه، ويعلن اســتمر ار إخلاصــهـ للخليفــة؛ يقول:
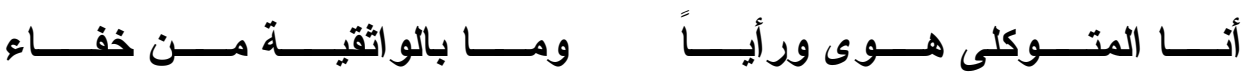
ولــيس بمؤيــسـى منــــه التخـــائى

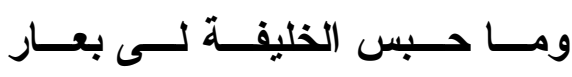

فرق له "المتوكل" وكاد يأمر بإطلاقه، ولكن الندماء تألبو ا عليه و انتدب لـــه

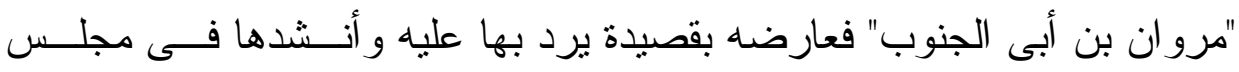

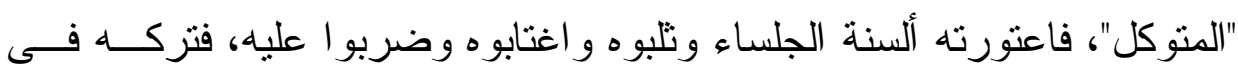

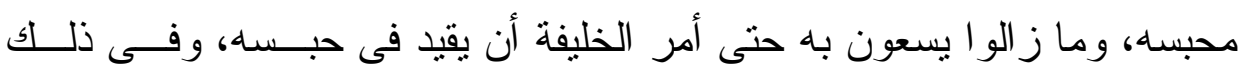
(من الطويل)

يقول (r):

$$
\begin{aligned}
& \text { انظر : الديوان ص: با، ـ ا. } \\
& \text { انظر : الديوان ص: ع ا. }
\end{aligned}
$$




\section{ملامح النجابة والفهم فى شعر على بن الجهم}

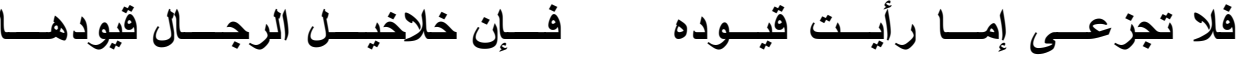
وله فى الحبس قصائد عدة أحسنها قصيدته البار عة التـى لــــــــلـ منلمهــا، و وأولها:

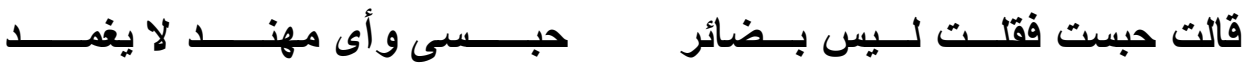
وفى كل ما قال لم يظهر جزعاً و لا هلعاً، ولم يتغير إخلاصه للخليفة، ولـــ يكف عن هجاء خصومه ومقار عتهم. ولنا وقفة مع هجائه سنعرض لها بعد.

ولم يشتف خصومه بكل ما ناله من أذى فأبلغو ا "المتوكل" عنه أنـــهـه هجـــاه فأمر بمصادرة أمو اله ونفيه إلى خر اسان بعد أن لبث فى السجن سنة، وكتب إلى ملى

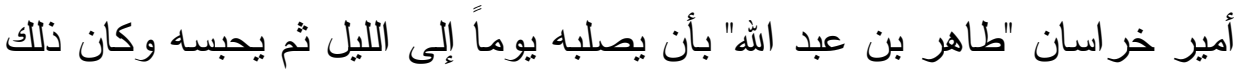
سنة qr و هـ فلما وصل إلى الثاذياخ وهى من ضو احى نيسابور حبسه "طاهر"

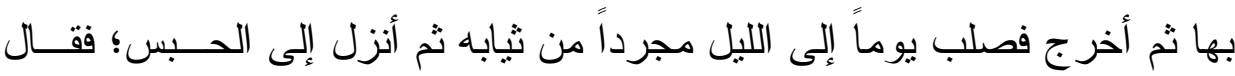
فى ذلك :

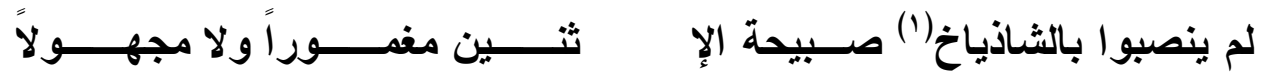
وفيها يشير إلى مصادرة أمو اله وما ناله من الظلم و العسف، دون أن يظهر

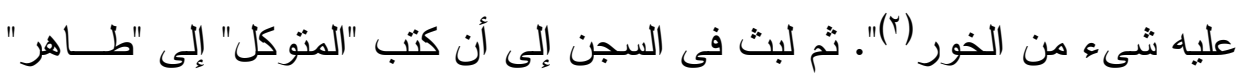
بإطلاقه، فلما أطلقه قال:

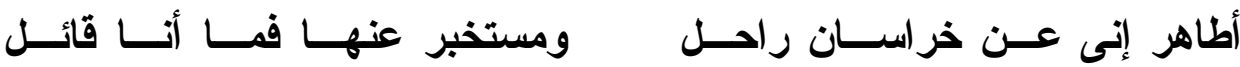

$$
\begin{aligned}
& \text { الثناذياخ: من ضواحى نيسابور أم بلاد خر اسان. } \\
& \text { انظر : الديوان ص (10 (1، } 7 \text { (1). }
\end{aligned}
$$


فقال له طاهر : لا تقل إلا خيراً، فإنى لا أفعل بك إلا خير اً ووصله وحملــهـ

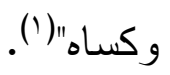

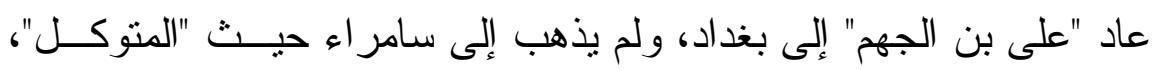
ولم يمدحه بشىء حتى قتل "المتوكل" فرثاه بقصيدة طويلة؛ وفيها يقول: شغلت بها عينـاً قـــلاً هجودهــــا

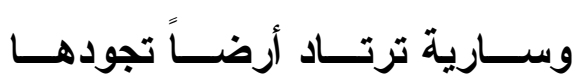
وسنعرض لها فى رثائه بعد. ويتميز شعر "على بن الجهم" فى هذا الغرض بأنه جزل رصين؛ فيه إحكام

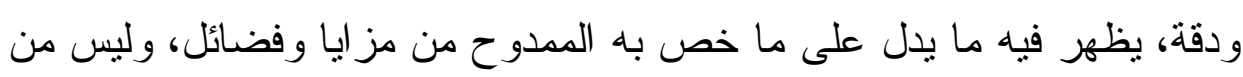

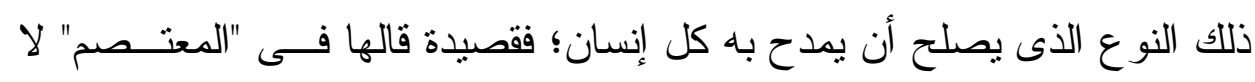

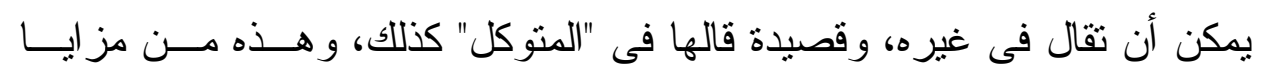

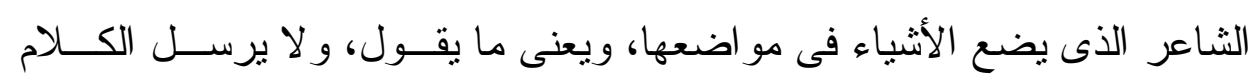

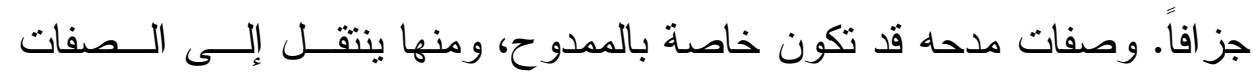
العامة ثم يركز ويؤكد عليها؛ فهى القصد من الثـعر و المقصودة مــن الــشاعر؛ فقصيدة فتح عمورية يعبر فيها عن تقدير الأمة لبطولة "المعتصم" و القضاء على يلى ولى

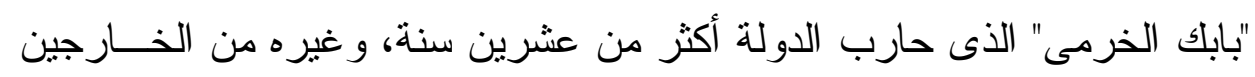
على الخلافة".

ولم يقل فى "الو اثق" إلا أبياتاً هى أثنبه بالأناثنيد وزناً ومعنى؛ فلم يجد فيــه

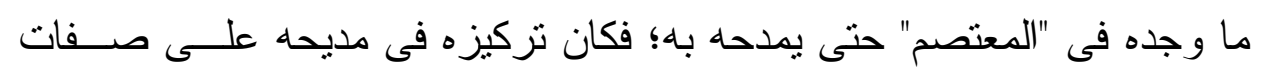
خاصة جداً عرضنا لها فى محلها من الدر اسة". 
فلما جاء "المتوكل" بعد "الو اثق" وكان متققاً معه فى الر أى و المذهب أكتــر

من مدحه وتفنن؛ قال قصيدة بعد بيعته بالخلافة شرح فيها خطة سير الخليفة فى الحكم وسياسة الأمة، وحمل فيها على المعتزلة وغــلاة الــشيعة، وهكــــا بقيــة قصائده فيه، لكل قصيدة صورة خاصة تتوه بخصائص الخليفة، وتتـرجم عــن معان وحو ادث تتصل برأى الثاعر ومذهبه، كما تتصل بفنه وشـاعريته، وهــذا من إصـابة الوجه فى مدح الخفاء مثله فى مدح الملوك كما قال قدامة بن جعفــر : فمثل قول النابغة الذبيانى فى مدح النعمان ابن المنذر:

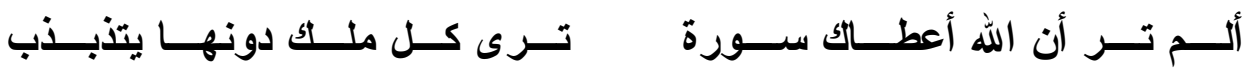

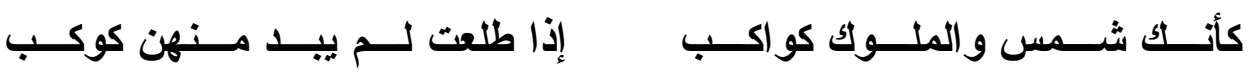
و منل ذللك قول نصيب فى سليمان بن عبد الملك:

قفاذات أو شال ومــولاك قــارب(')

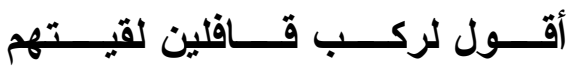
ومنل قول "على بن الجهم" فى "المعتصم":

علــــى الخلفــــاء بـــــالنعم العظـــــام

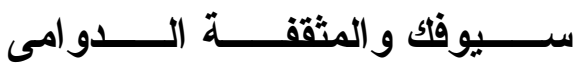

بـوادر مـــن عزيــز ذَى انتقـــام

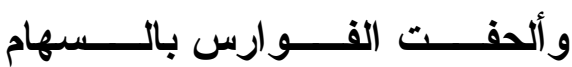

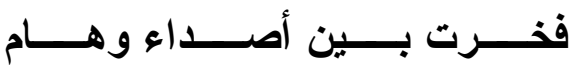
المنعم خفاجى، دار الكتب العلمية، بيروت لبنان، دون تاريخ. 


$$
\text { وقوله: - و }
$$

يجـلـ عــن المفــاخر و المـسـامى

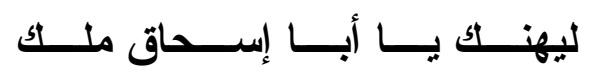
عزى الإسلام مسن بعـــ انفـصام لــسيفك دانـــت الــــنيا وشـــــت

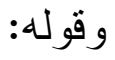

مــن الأتـــر الك مــشرعة الــسهام

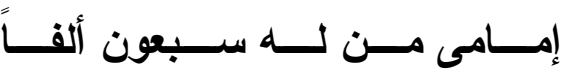

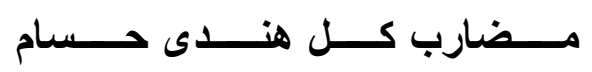
إذا ما غــضبوالـــين الله أرضــوا فكل الصفات المذكورة صفات عامة تهــم الخلافــة و المـسلمين وتـسطر

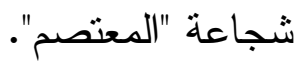

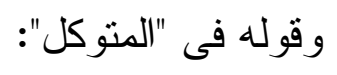

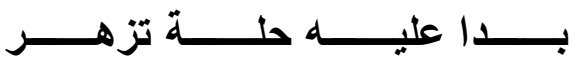

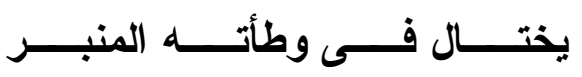

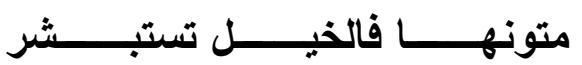

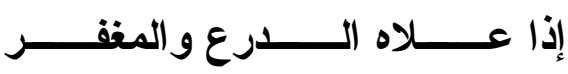

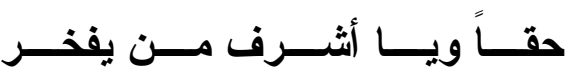

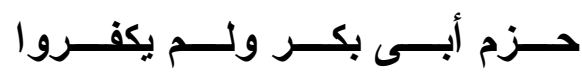

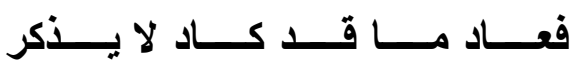
مــن معسشر مـــا مسـثهم معسشر
أحســـسن خلــــــ الله وجهـــــــاً إذا وأخطــــب النــــاس علــــى منبــــر وتطــــرب الخيــلـل إذا مـــــا عـــلا

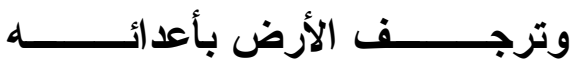
وقوله: - و يـــا أعظـــم النــاس عــــ مـــلم

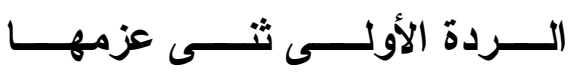

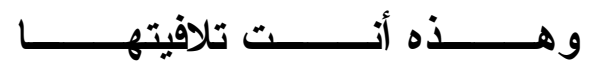

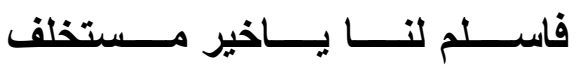
فالمتوكل عندما يمتطى الخيل تطرب له وتستبشر لعلمها بأنه يريـــــــــلك

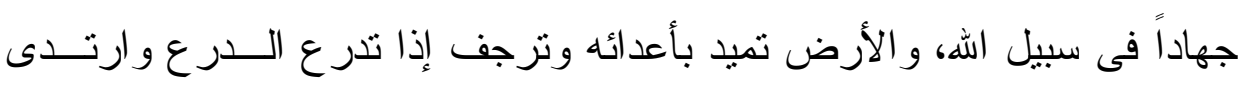




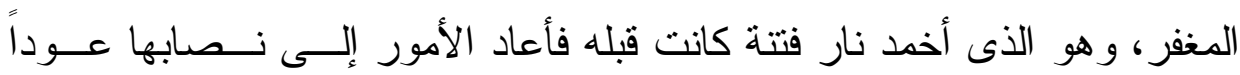

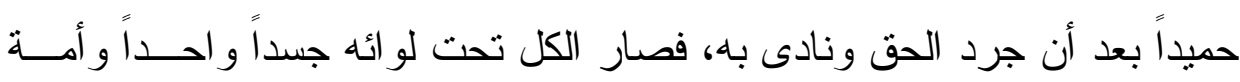

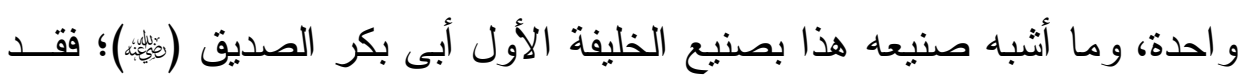

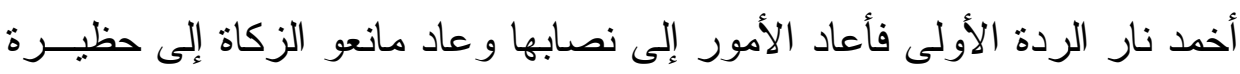
الدين وكنف الإسلام. وكل ما ذكر من صفات للمتوكل هى صفات الخليفة إمــام

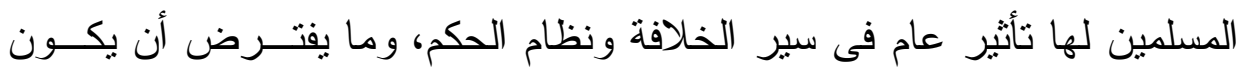

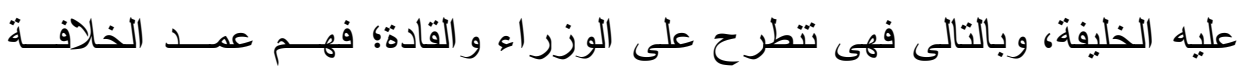
و عليهم تقوم وتبقى، و هذا ما عناه "قدامة بن جعفر" عند ذكره إصابة الوجه فـى

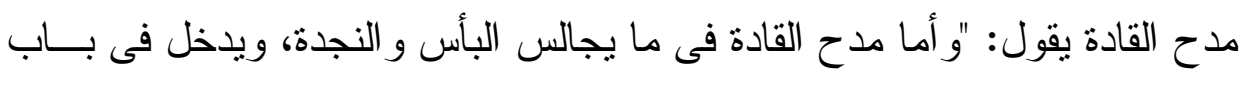
شدة البطش و البسالة فإن أضيف على ذللك المدح الجود و السماحة و التخرق فـى لـى

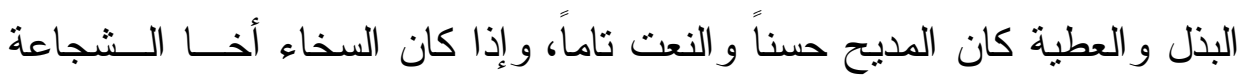

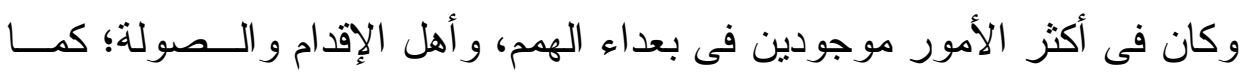
قال منصور النمرى فى إفر اده ذكر البأس وحده:

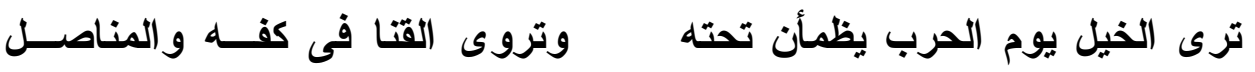

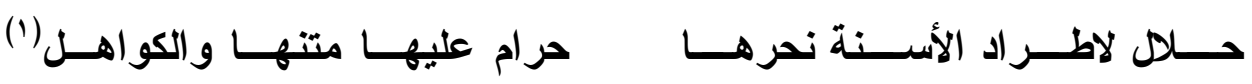
ولما افتتحت أرمينية وقتل إسحق بن إسماعيل دخل "على بن الجهم" علــى

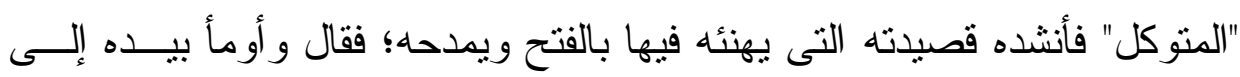
الرسول الوارد بالفتح وبر أس إسحق بن إسماعيل.

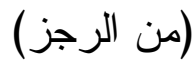

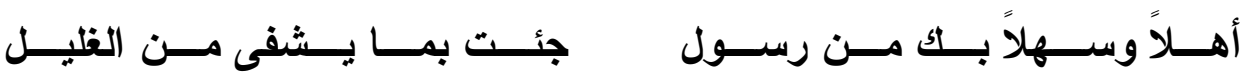

$$
\text { انظر : نقد الثعر لأبى الفرج قدامة بن جعفر ص (9 • (). }
$$




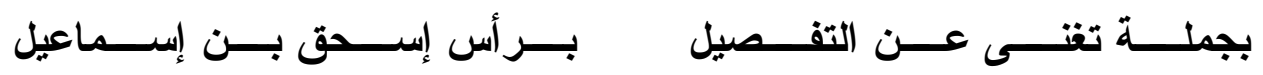

\section{قهراً بلا ختل ولا تطويل}

فاستحسن الجميع ارتجاله هذا و ابتداءه، و أمر لله "المتوكل" بثناتـين ألــــ

درهم، وتمم القصيدة التى بلغت أبياتها سبعة عشر بيتاً (1).

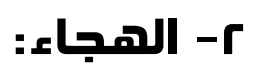

ظل المديح حتى العصر العباسى متصداً بالعلية من القوم خلفــاء ووزر اء

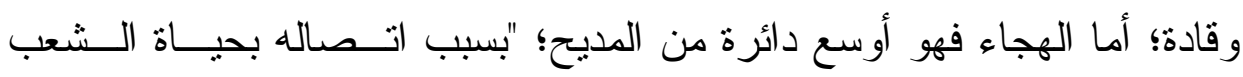

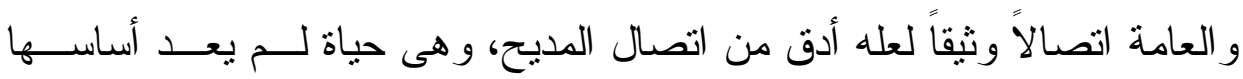

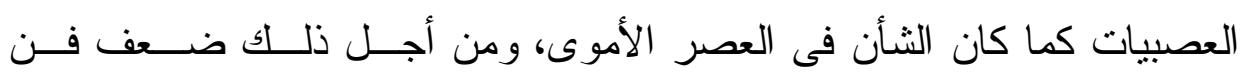
النقائض لقيامه عليها إلا أسر اباً قليلة كانت تظهر من حين إلى حين. ولكــن إذا كان هذا الفن ضعف؛ فإن الهجاء لم يضعف بسبب التنافس الثديد بين الثعر اء، وقد عمت فيه روح جديدة، إذ أخذو ا يريشونه سهاماً مصمية، ويخيل إلى الإنسان

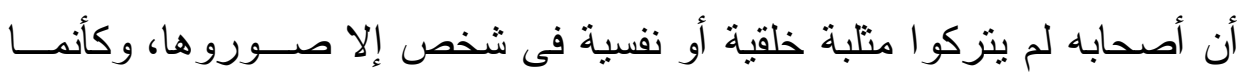

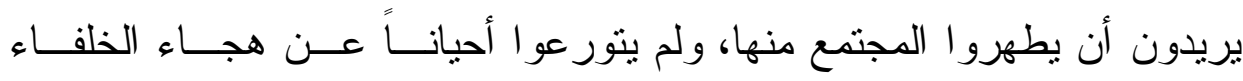
و الوزر اء، كلما رأو هم ينحرفون عن الجادة على نحو ما هو مشهور عن دعبل. وبذللك يصبح الهجاء الصحيفة التربوية للمديح؛ فالمديح يرسم المثاليــة الخلقيــة

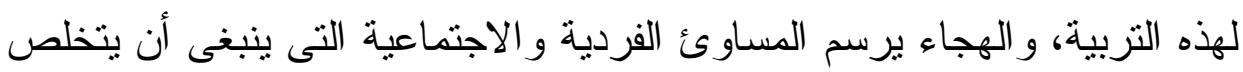

منها المجتمع الرشيد"(؟).

$$
\begin{aligned}
& \text { انظر الديوان ص (r9 (1). }
\end{aligned}
$$

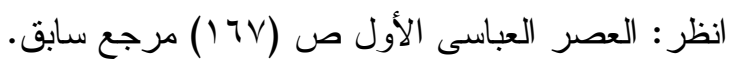


كان "على بن الجهم" مبالاً إلى التحرش برجال الدولــة و التـــرس بهــم،

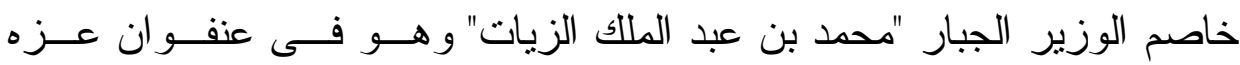

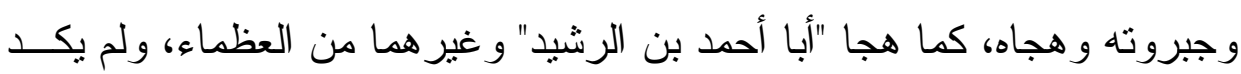
يسلم من لسانه أحد من ندماء "المتوكل"، مع ترفع عن منازلة غير الأكفاء"('). قال المسعودى فى مروج الذهب عن "على بن الجهم": ".... وكـــان فــى

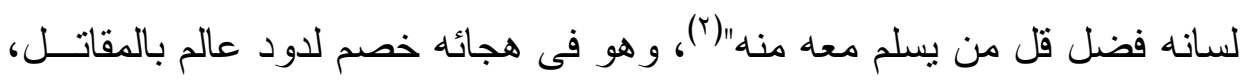
لا يتورع عن هتك الأعر اض و انتهالك الحرم بالجد و السخرية، وتتنابه فى هجائه

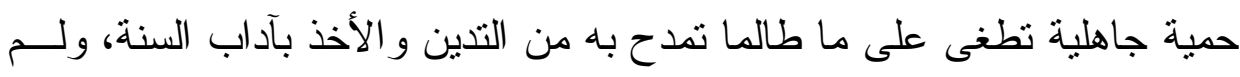

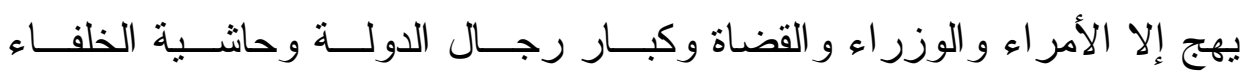

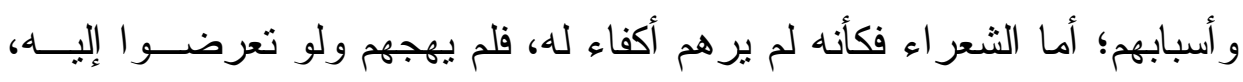
هجاه "البحترى" ثلاث مرات فلم يجبه، و هجاه "مروان بن أبى الجنوب"، بحضرة "المتوكل" فى مجلس من مجالس سمره؛ فقال:

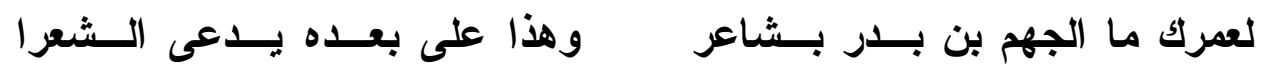

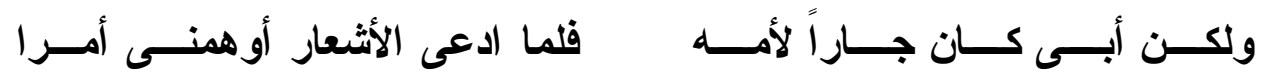

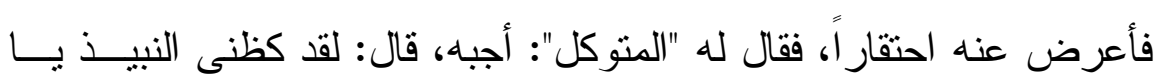
أمير المؤمنين، قال هذا عى و لابد من إجابته، فأطرق ساعة ثم قال على بالــدواة

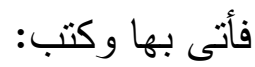

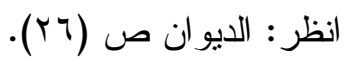

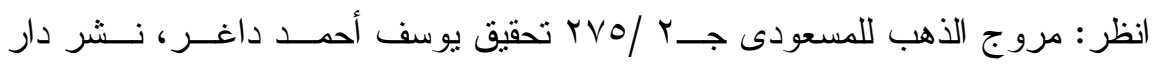

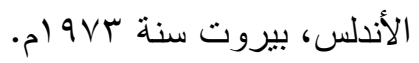


عداوة غيـر ذنى حسبب وديـن (1)

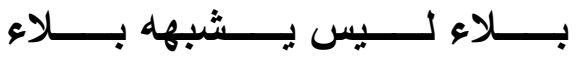
ويرتع منك فـى عـرض مسـصن

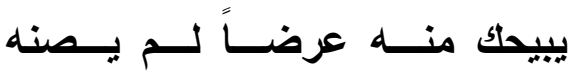
ورد هجاء "على بن الجهم" فى قصائد أخلصها لهذا الغرض، أوطى قصائد مديح، ونجده لم يهج خليفة ولم يذمه؛ فقد كان يرى فيه إمام المسلمين و أســوتهم وقدوتهم الطيبة، وقد خص الخلفاء بالمديح وخص المديح بالخلفاء؛ فكيف يتـأتى له أن يمدح خليفة اليوم ثم يهجوه غداً، أو أن يمدح خليفة ويهجو خليفة آخر؛ لقد

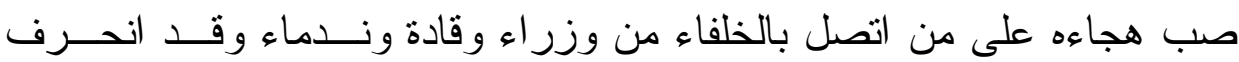

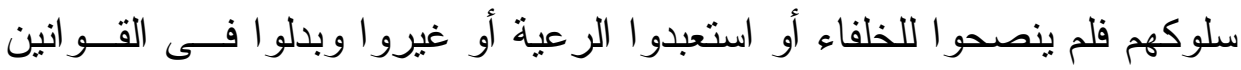
و الأعر اف كما يحلو لهم دون رقيب من ضمير أو وازع من دين، وهو فى هـــا يريد تقويم سلوكهم المعوج، فمن استجاب فهو خير له، ومن لم يستجب فقد شهر به فى شعر يرويه الناس وتشير به الركبان ليكون عبرة لغيره. وممن هجاهم ابن الجهم "أحمد بن أبى دؤ اد" قاضى القضاة، وكان منحرفــاً عن "على بن الجه"؛ لاعتقاده مذهب الحشوية، فلما حبس "على بن الجهم" ســـأل ابن أبى دؤ اد أن يشفع فيه فلم يفعل، فلما سخط "المتوكل" على "ابــن أبـى دؤ اد"

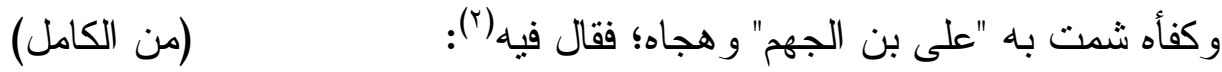

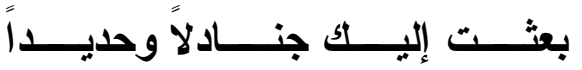

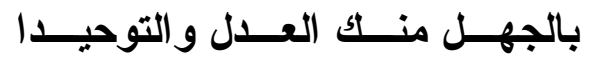

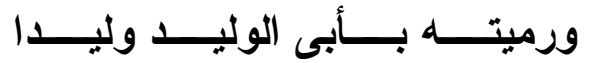

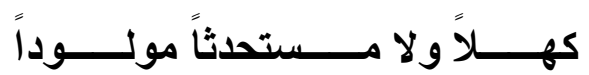

بــا أحمـــ بــن أبــى دؤاد دعــوة

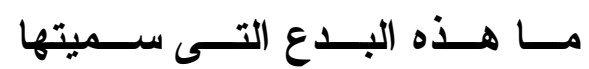
أفسدت أمــر الــدين حسين وليتــهـ

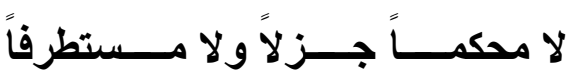

$$
\begin{aligned}
& \text { انظر : الديوان ص (r) ). } \\
& \text { انظر : الديوان ص (99). }
\end{aligned}
$$


ذكــــر القلايــــــا مبـــــئاً ومعيـــــاً

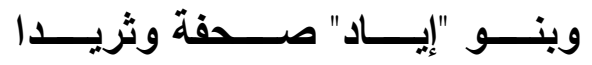

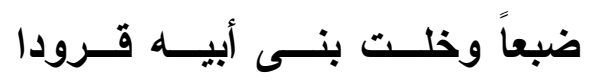

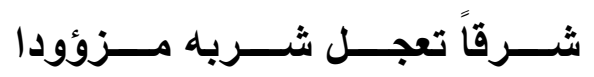

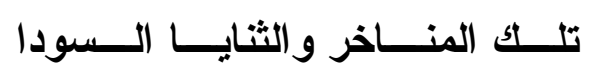

شــرهاً إذا ذكـــر المكــارم والعــلا

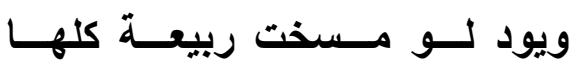

و إذا تربــــع فــى المجـــالس خلتــــه

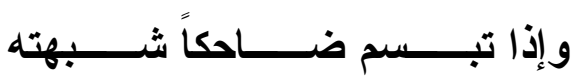
لا أصبحت بالخير عـين أبـصرت

صب جام غضبه فى هجائه "أحمد بن أبى دؤ اد" بسبب ما أحدثه فى الــدين

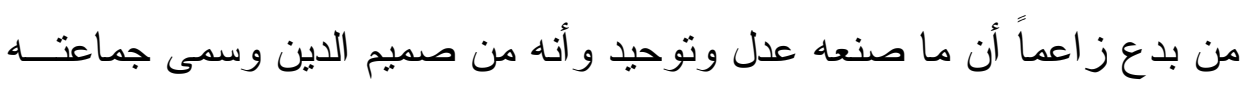

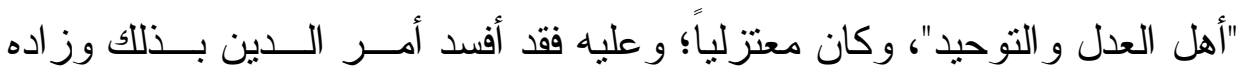

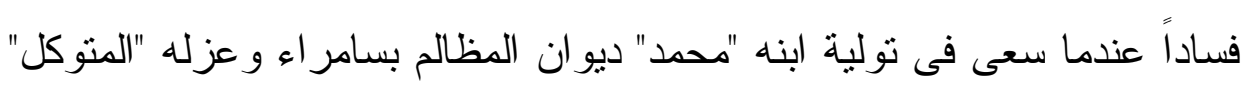

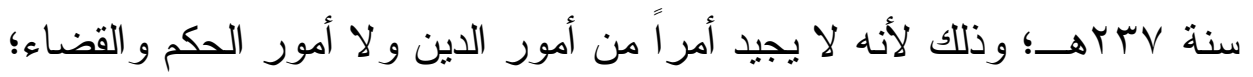

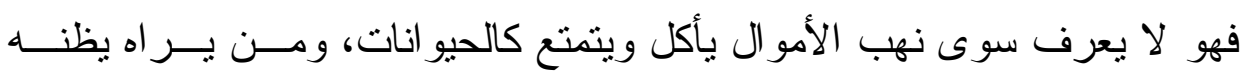
ضبعاً، و إذا تبسم كمن شرق بشربه متعجلاً فلا بارك اله فى عين رأت مناخره أو ثناياه السود.

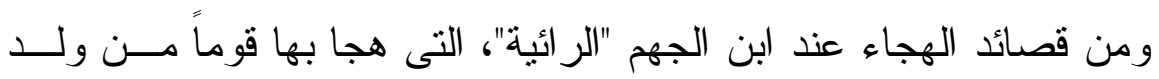

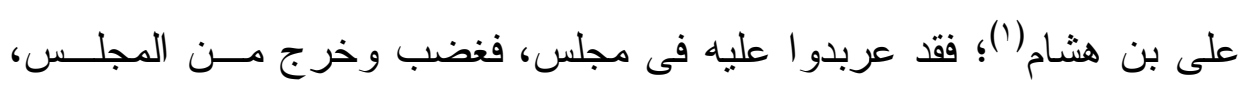
و اتصل الثر بينهم حتى تقاطعو اوهجروه و عابوه و اغتابوه؛ فقــال يهجـــوهم (؟): (من البسيط)

و لاه المأمون عدة أعمال آخر ها "أذربيجان"، فبلغه أنه يظلم الناس ويأخذ أمو الهم، ويقتل

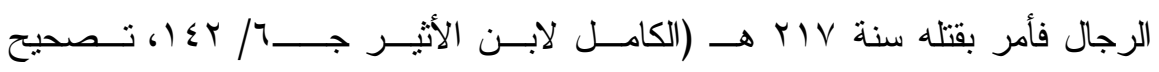

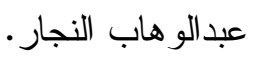
انظر : الديوان ص (1) (I )). 


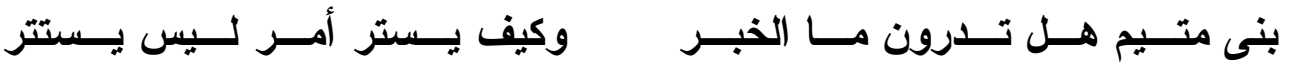

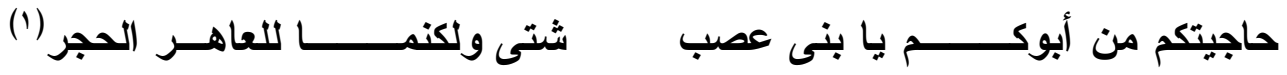

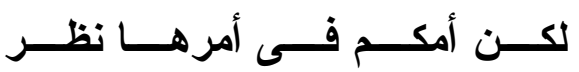
محجوبة دونها الحــراس والـستر وغير ممنوعة مـنهم إذا ســكروا لا يمكن الثيخ أن يعصى إذا أمروا

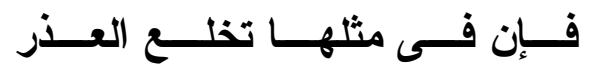
من كسل لاقحسـة فــى بطنهــا درر

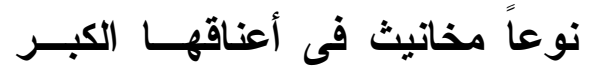

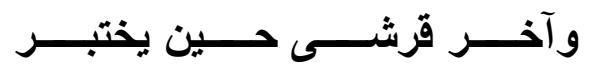

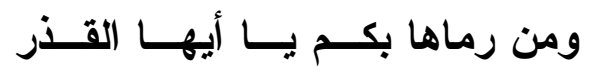

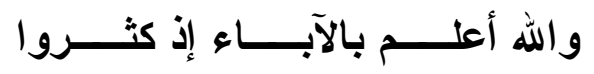

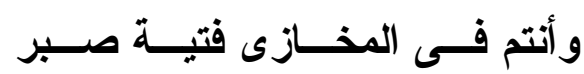

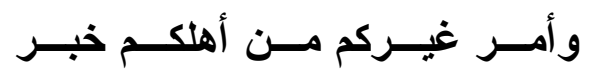

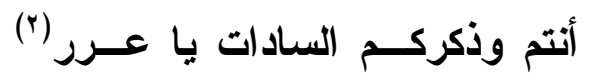

قد كسـان شـيخكم شـــيخاً لــه خطــر

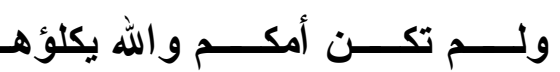

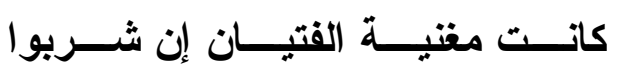

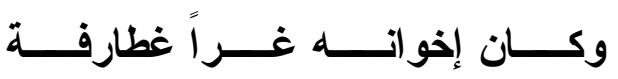

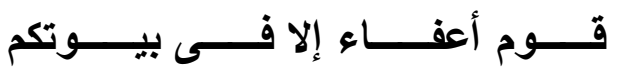
فأصــبحت كمــراح الــشول حافلـــة

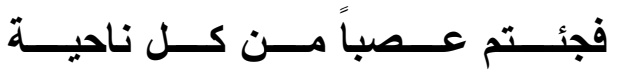

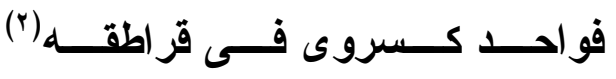

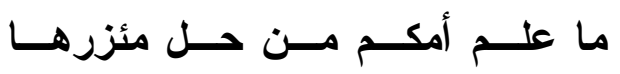

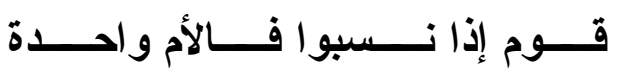
لم تعرفوا الطعـن إلا فــى أســافلكم

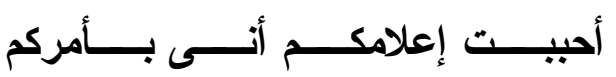

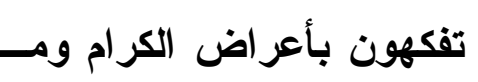

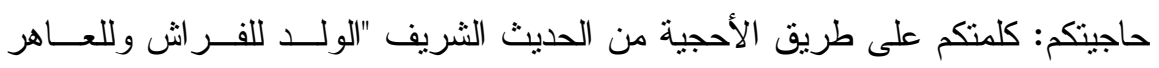

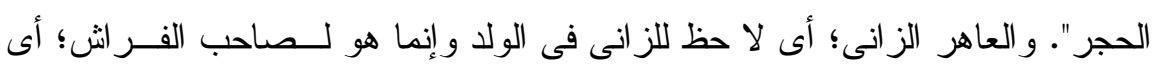

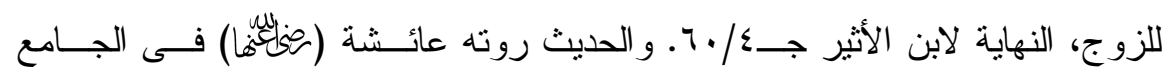

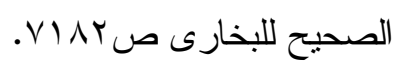

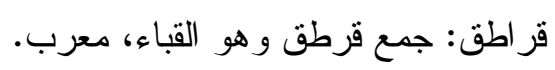


هذا الهجاء الــى تبقــى مياســمه(1) على جبــاهكم مـــا أورق الـشجر صدق ابن الجهم عندما سمى هذا الهجاء ووصفه بأنه سمة لا تزول عـنهم

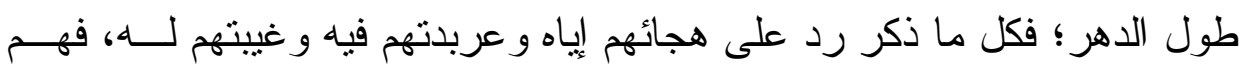

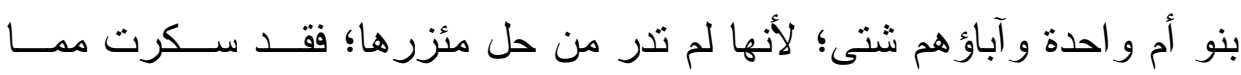

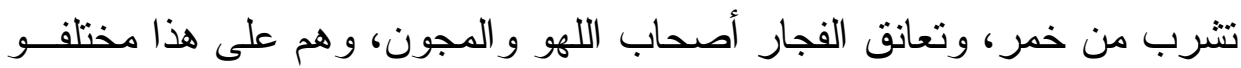
النسب؛ فو احد كسروى أبوه فارسى، و آخر قرشى أبوه عربى، وقد استحقو ا هــــا

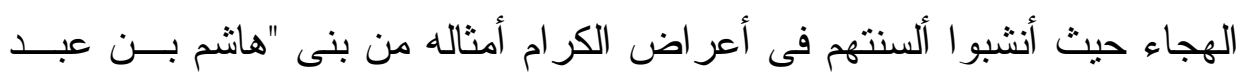
مناف"، وما كان لهم أن يصنعو ا ذلك معه.

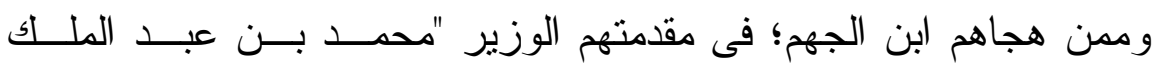

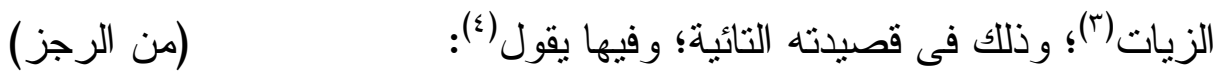

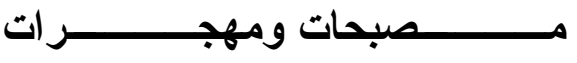

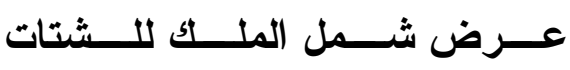

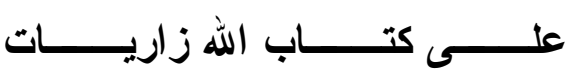

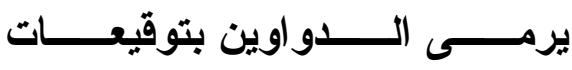

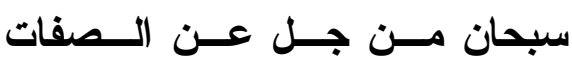

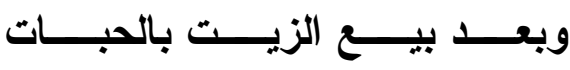

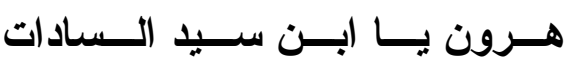

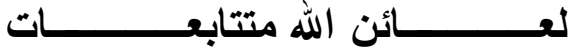

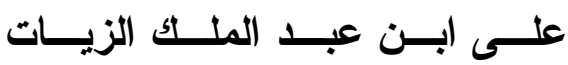

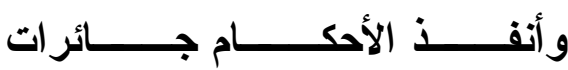
وعـن عقــول النـــاس خارجــات

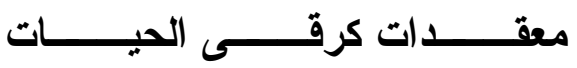
بعد ركوب الطـــوف فـــى الفــــرات

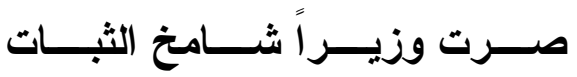

$$
\text { المياسم: جمع ميسم وهو هنا أثز الوسم. }
$$

العرر: جمع عرة هو الرجل يكون شين القوم؛ يقال فلان عرة أهله.

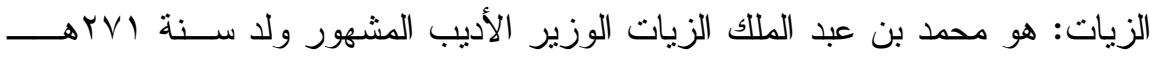

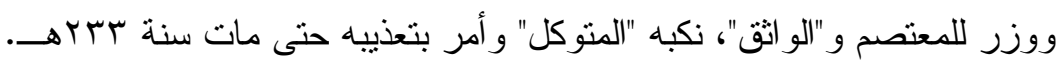

$$
\text { انظر : الديوان ص (1) (1). }
$$


اة

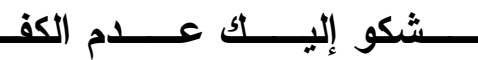

أمـــــا تـــــى الأمــــور مهمـــلات

من بعـــ ألــف صـــب الأصــــات

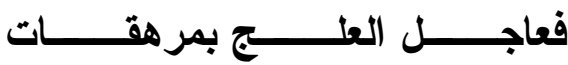

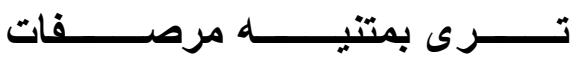

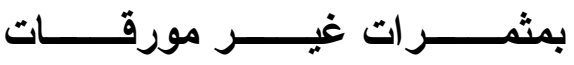

ترصف الأسنان فى اللثات

استتزل اللعنات المتتابعات صباح مساء علــى رأس هــذا الـــوزير الــذى

عرض الملك أيام "الو اثق" للشتات حيث خرج بأحكام ليست من الثرع الحنبـــ

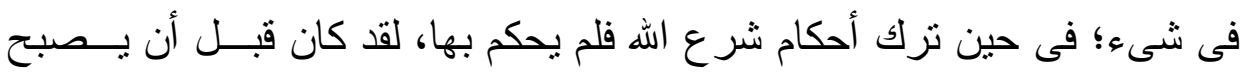
وزيراً يبيع الزيت بالحبات، ويصيد السمك من البحر؛ فمن أدر اه بقوانين الخلافة التى هى أحكام الله، وهنا يطالب "ابن الجهم" الخليفة "الو اثق" أن يقيل هذا الوزير

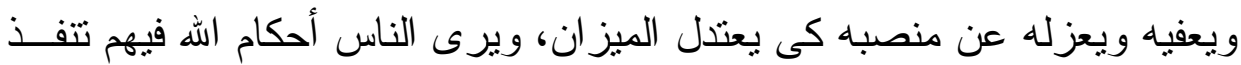
فيعم العدل و المساو اة وينتشر الخير وتعم البركة.

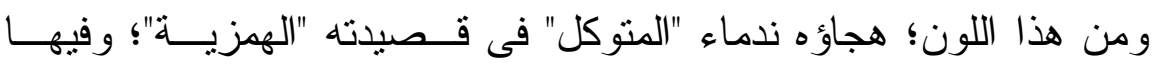

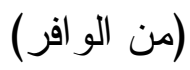

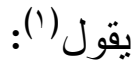
وســـــلمنا لأســــــباب القـــــاء توكلنــــــا علــــــى رب الـــــسماء وفيها يقول أيضاً:

فهـــــم تبــــع المخافـــة و الرجـــــاء توق الناس يــا ابــن أبــى وأمسىى لأمـــر مـــا غـــا حسـسن الإخـــاء ولا يغـــررك مـــن وغـــــ إخـــاء وهـــــــــالأمس إخـــوان الــصفاء ألــــم تـــر مظهــرين علــى غــــا

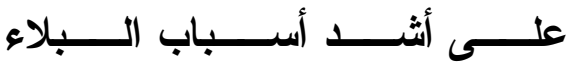
بليـــت بنكبـــة فغــــوا وراحـــوا 


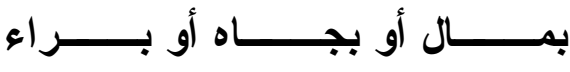

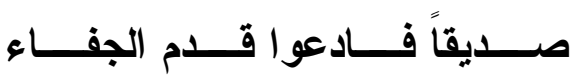

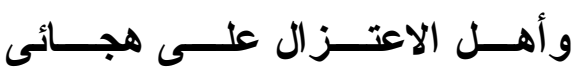

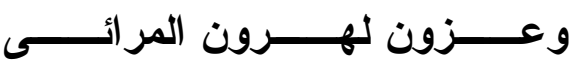

بجــــماء اللــسـان عــن الختـــاء

ســــوى علمــــى بـــــأولاد الزنـــــاء

فما فضل الرجــال علــى النــــاء

وعوداً فى الصباح وفـى المسـساء

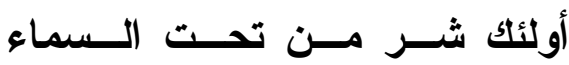

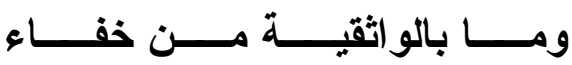

ولـــيس بمؤيــسـى منـــهـ التتـــائى
أبــــت أخطـــــارهم أن ينــــصرونى

وخـــافوا أن يقـــال لهـــم خـــلتم

تــضافرت الـــرو افض و النــصارى

فبختبـشوع يـشـهـ لابـن عمـــرو

وما الجـــماء بنـــت أبــى ســمير

وعـــابونى ومــــا ذنبــــى إلــــــهم

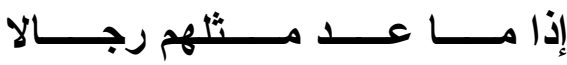

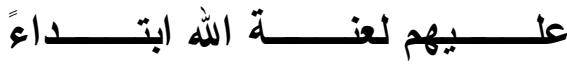

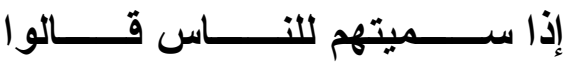

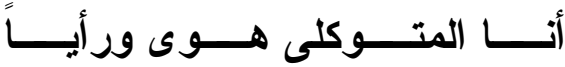

ومــا حـبس الخليفــة لــى بعــار

هذه القصبد أول ما قال فى الحبس كتب بها إلى أخيه لبوصلها إلى الخليفــة "المتوكل"، وفيها يظهر تجلده وصبره على حبسه ما دام هذا يرضــى الخليفــة،

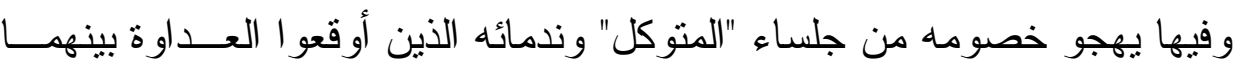
بعد المودة التى كانت تجمعهما حتى أمر بحبسه، وفيها يعلــن تمـسكه بمذهبـــه السياسى ور أيه فى خلافة بنى العباس؛ فر أيه وهو اه معهم، وهم أولى من غير هم

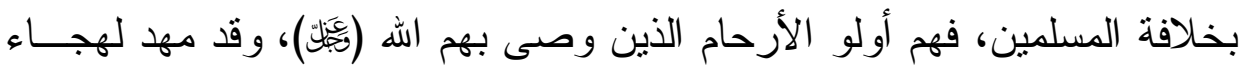
خصومه بوصية غالية لكل الناس فعلى المخلصين مــنهم أن يحــذروا صــداقة الخائنين الأوغاد، وأن يتحروا التقة فى اختيار الأصدقاء فكم من و غد ليس مــن

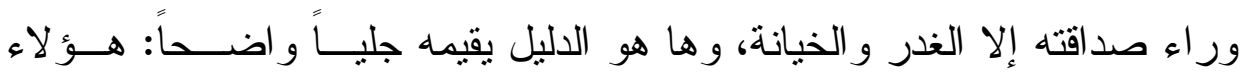

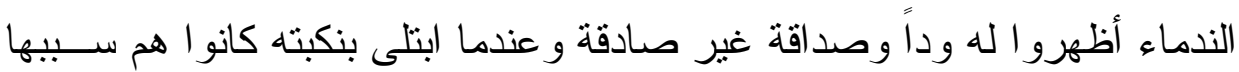
حتى سجن وقيد فى سجنه وكان يرجو منهم شفاعة فلم يجدها، فـسجل علـــهم 
هجاء فى شعر يروى ونسير به الركبان؛ فهم رو افض ومعنزلة ونصسارى وهـــ

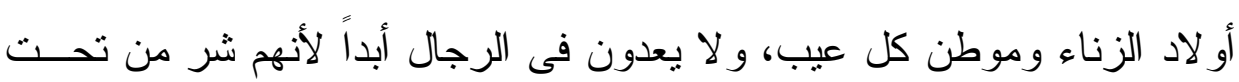
السماء.

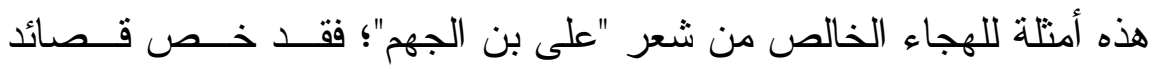
بعينها أو أبياتاً تحمل هجاء من أر اد هجاءه رداً عليهم ما صنعوه معه من هجاء. وهناك لون من الهجاء ورد ضمن قصائد مدح ومن قـصـائد هــذا اللـــون قصيدة: "هذا العقيق"؛ وفيها يمدح "المتوكل" ويهجو أعداءه الذين ظلموهو وظلمــو ا الرعية باسم الخليفة وبحكم منصبهم فى دولة الخلافة حتى جاء "المتوكل" فأعانه ربه عليهم و اقتص منهم؛ وفيها يقول ('):

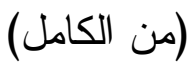

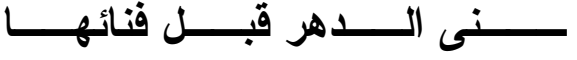

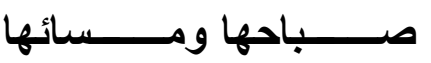
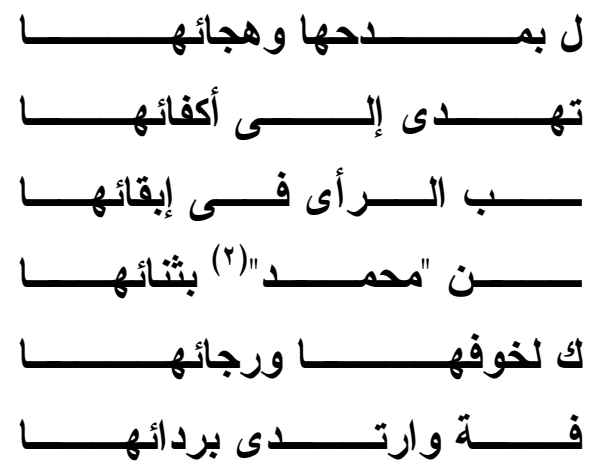

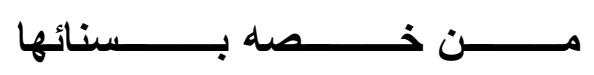
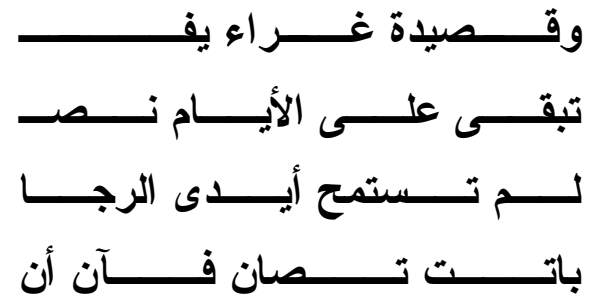

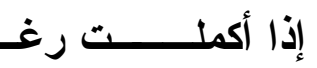
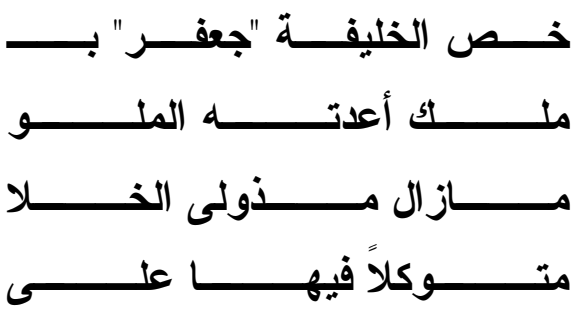

انظر : الديوان ص (17).

جعفر بن محمد: هو المتوكل بن المعتصم. 


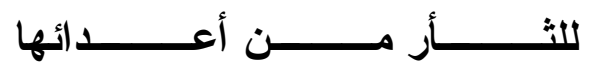

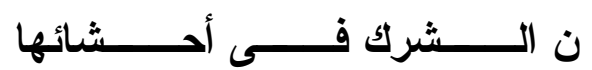

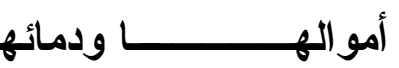

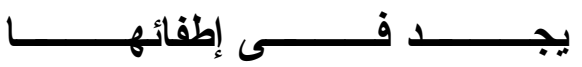

(')

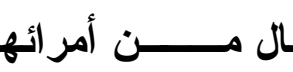

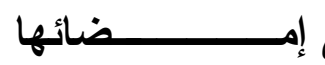

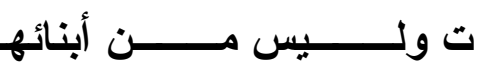

$(\ulcorner)$

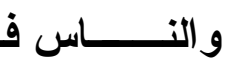
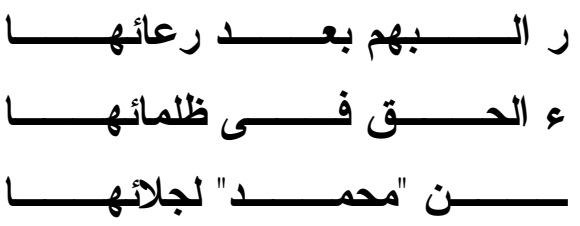

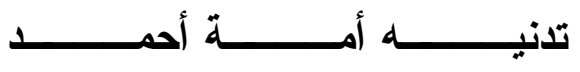

مـــن بعـــــ مــــا طعنــــت قــــرو
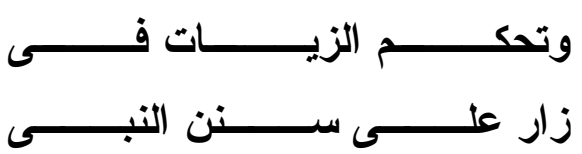

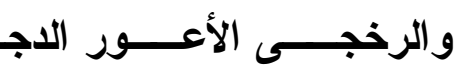

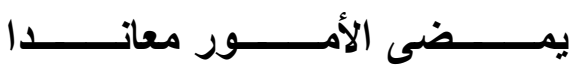

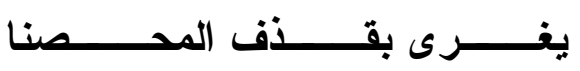

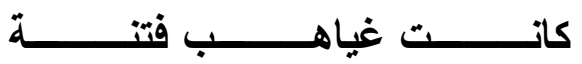

تص

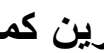

متحم

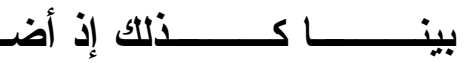

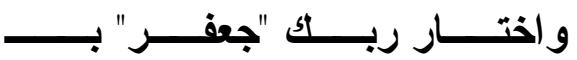

خص "المتوكل" بالمدح وبنى ذلك على ما قام به فى سبيل إطفاء تلك الفتتة

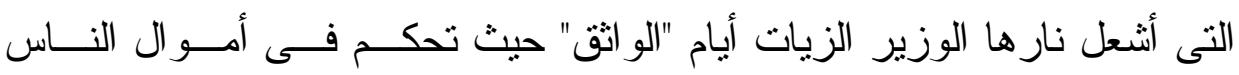
ودمائهم يقضى بما يشاء ويحكم بما يريد و لا ر ادع لله من دين، و الرخجى الــذى لـى

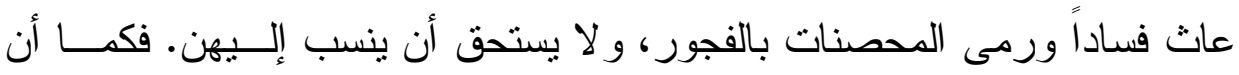
القصيدة فى مدح "المنوكل" فقد حملت هجاء اثثين من الفساق المتجبرين.

الرخجى: هو عمر بن فرج الرخجى كان من بطانة "الواثق"، وكله على أخيه "المتوكل"

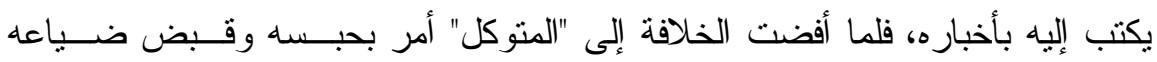

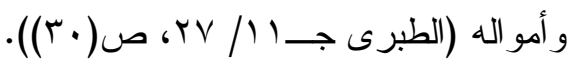

$$
\begin{aligned}
& \text { انظر : الديوان ص (آلآل). }
\end{aligned}
$$


ومن هذا النوع أيضاً قصيدته الدالية: "قالـــت حبـست" (1)؛ وفيهــا يمــدح "المتوكل"، ثم يهجو أعداءه الذين كادو الله عند "المتوكل" ويقول: (من الكامل)

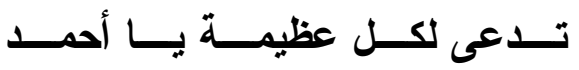

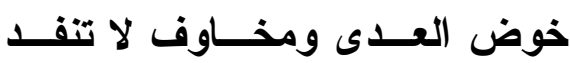

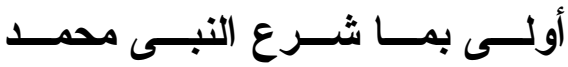

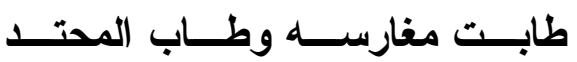

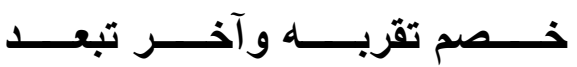

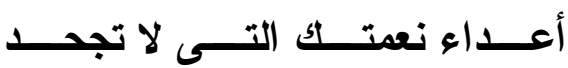

فينا ولـيس كغائسب مــن يـشهر

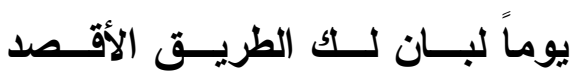

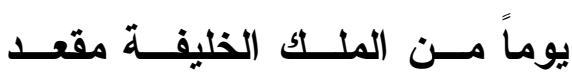

لقلجت فى حججــى وخــاب الأبعـــ

و إليـــك مــصدرنا غـــاً والمــورد

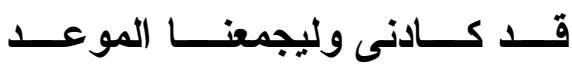

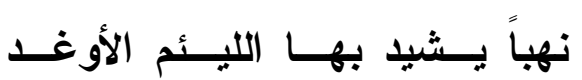

يـــا أحمــــــــن أبـــى دؤاد إنمــــا

بلــــغ أميـــر المــــؤمنين ودونـــــهـ

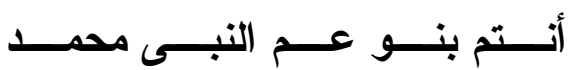

ما كان مـن حسـن فـأنتم أهــــه

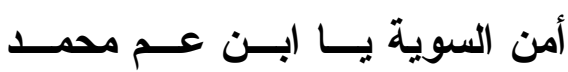

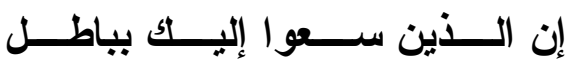

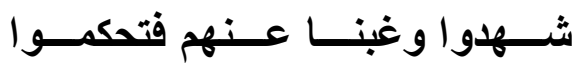

لو يجمع الخصمين عنـــك مـشهر

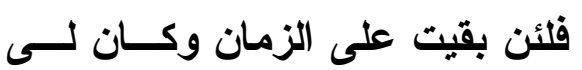

واحتج خصمى واحتججت بحجتى

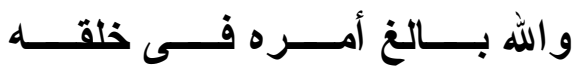

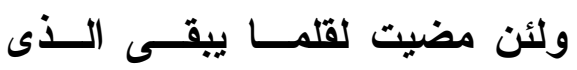

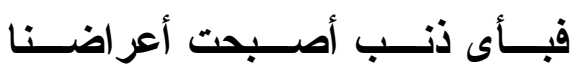

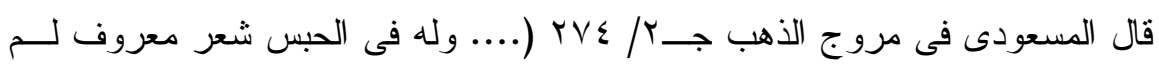
يسبقه إلى معناه أحد وهو قوله: "قالت حبست)، وقال أبو الفرج الأصفهانى فى الأغانى

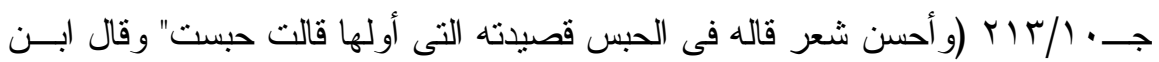

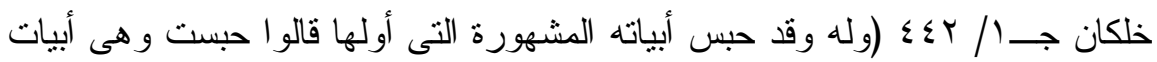

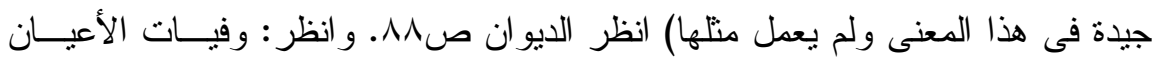
لابن خلكان جـ / آ ـ ـ تحقيق إحسان عباس، دار النقافة، بيروت. 


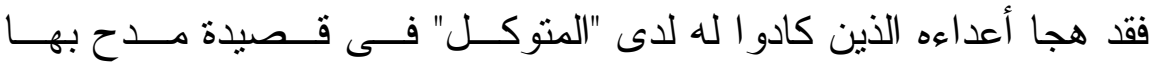
"المتوكل"، وفيها بطلب من "أحمد بن أبى دؤ اد" أن يبلغ الخليفــة منـــهـ رســالة يوضح فيه كيد الكائدين له عنده فهم إن كادو ا شخصه اليوم فـسيكيدون للخليفــة غداً وللإسلام بعد غد، وكيف يحدث هذا ويعلم بذلك "المتوكل" وهو من قــوم لا لا ئل يصنعون إلا الحسن الجميل الصادق؛ وليس من ذللك خصم يقـرب ويـسمع لــــ افتر اؤه وكذبه وكيده، وخصم يبعد دون أن يسمع له قول أو تتاقش لـــه حجــة، و هل من شهد فتحكم فى رقاب الغائب يتساوى به من غاب، ولو جمع الخصمين مجلس للى الخليفة لقامت الحجة على الاليل وسطع البرهان سطوع الثمس فـى

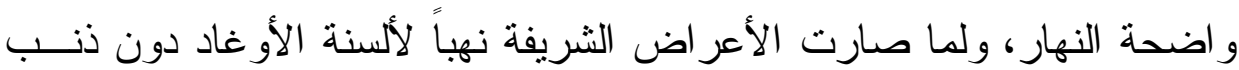
أو جريرة.

\section{ومن خصائص هذا الغرض نعرض لما قاله قدامة فيه:}

يقول "قدامة بن جعفر" فى نعت هذا الغرض: "إنه قد ســــل الــسبب إلـى معرفة وجه الهجاء وطريقه ما تقدم فى قولنا فى باب المديح و أســبابه، إذ كــان الهجاء ضد المديح، فكلما كثرت أضداد المديح فى الشعر كان أهجى له ثم تتزل

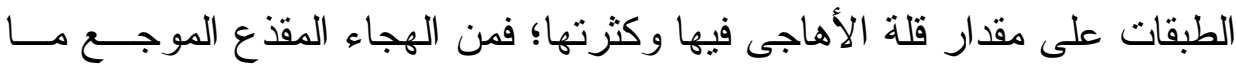

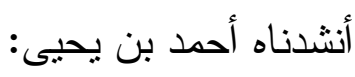

ولا تبغ من سعد وفــاء ولا نــصرا

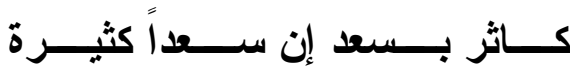

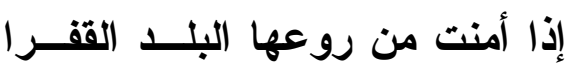

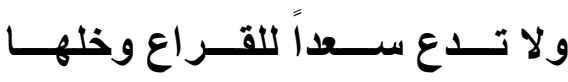
وتزهد فيهــا حسين تقتلهـــا خبــرا يروعلك من سعد بن عمرو جسومها فمن إصابة المعنى فى هذا الهجاء أن هذا الشاعر سلم لهؤلاء القوم أمرين

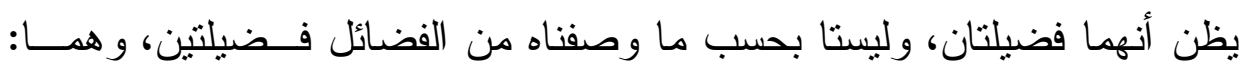
كثرة العدد و عظم الخلق، وغز ا بذلك مغازى دلت على حذقه فى الثُعر؛ منهـــا: $-1 \cdot r-$ 
أن أدخل لهم هجاء فى باب الأقو ال الصادقة لإعطائه إياهم شيئًا ومنعه لهم شيئًا آخر وقصده بذلك أن يظن أن قوله فيهم إنما هو على سبيل الصدق وذكره إياهم بما فيهم من جيد وردىء. ومنها: ما بان من معرفتـــهـ بالفــضائل حتــى يميــز

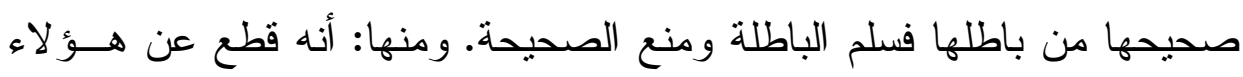

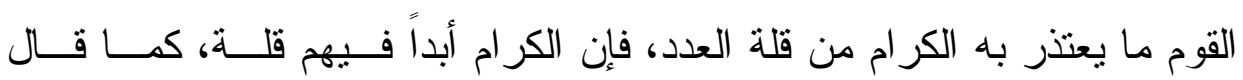

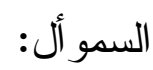

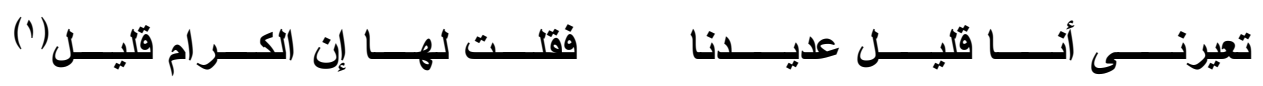
نقول فهل سلك ابن الجهم هذا المسلك أو أتى بما يشبهه فى هجائه هذا مـــا سنعرفه فى الصفحات القادمة. ذكرنا من قبل أن ابن الجهم قد صب جام غضبه وهجائه علــى الـــوزر اء

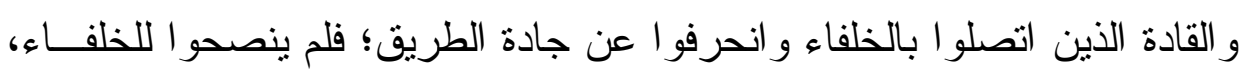

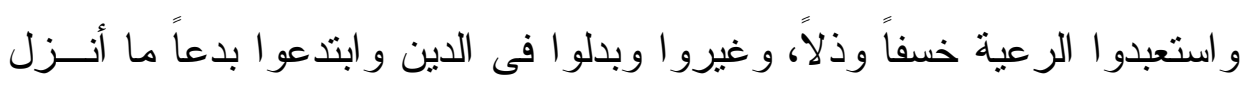
الله بها من سلطان؛ فهم فى رأيه خارجون مضللون بستحقون الهجاء، أما الخلفاء فهم القادة و الحكام وخلفاء المسلمين هم الأسوة و القدوة و الرمز الأعلى للإســلام

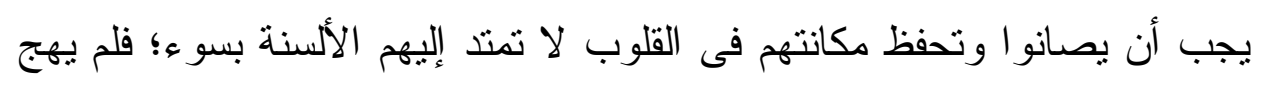
خليفة قط لعلمه بسمو مكانتهم وقداسة منزلتهم، فكان كل مديحه فيهح وكل ثتائـــه عليهم، وقد وضحنا من قبل كيف قصر ابن الجهم مديحه على الخلفاء من بنـى العباس، وكان يفخر بأنه من أهل خر اسان الذين ناصروا الخلافة العباسية فقامت ولن

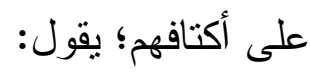

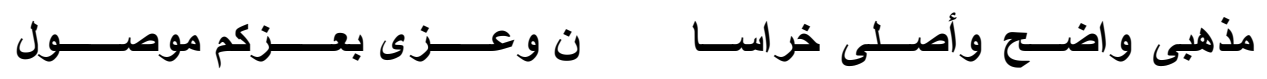
انظر : نقد الشعر ص (r (1))، مصدر سابق. 
ويقول:

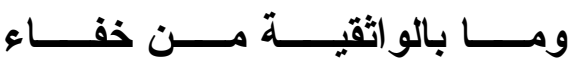

أنــــــا المتــــوكلى هـــــوى ورأيـــــا

ويقول:

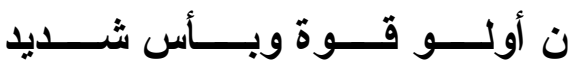

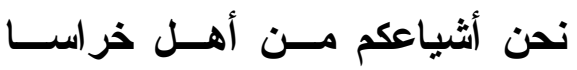

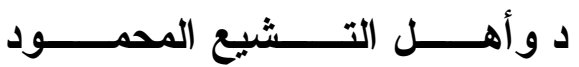

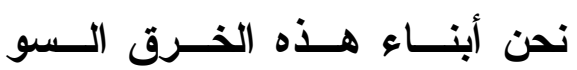

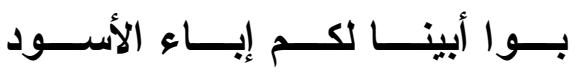

إن رضيتم أمسـراً رضــينا وإن تـــأ

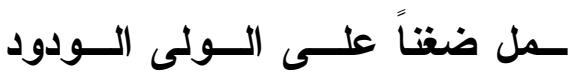

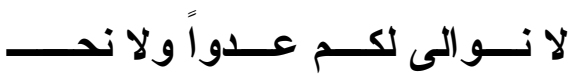

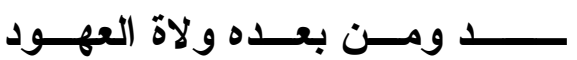

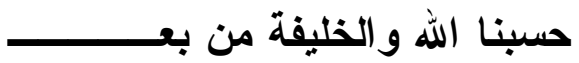

فاقتصر هجاؤه على الوزر اء و القادة، كما اقتصر مديحه على الخلفاء، ولم

يهج أقر انه من الثعر اء فكان ير اهم دونه منزلة حتى لو تعرضو اله له بالهجاء إلاء ولاء

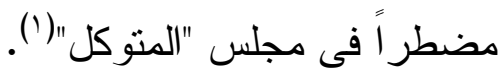

وقد قسمنا هجاءه كما ورد قسمين: منه ما ورد ضمن قـصائد مــدح لأن

السياق اقتضاه و الموضوع طلبه، ومنه هجاء خالص انفردت به قصيدة أو عـدة أبيات، وكلا النوعين باندر اجهما تحت غرض الهجاء لايفترقـان فــى الــسمات

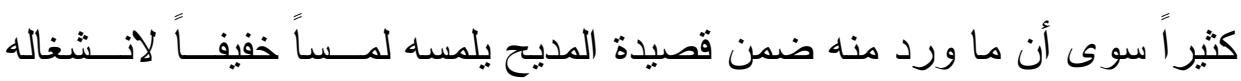
بصفات الممدوح وتعدادها؛ فهى فى رأيه الغرض الرئيس و الموضوع الأصــيل الذى إليه يرمى ويهدف، ثم يطوى فيه هجاء من أر اد هجاءه، وله من السمات ما سنعرض لله فى محله من الدر اسة.

انظر هذه الدر اسة ص (^^). 
وحديثنا الآن عن النوع الذى انفردت به قصيدة أو عدة أبيات وفيه نجد ابن

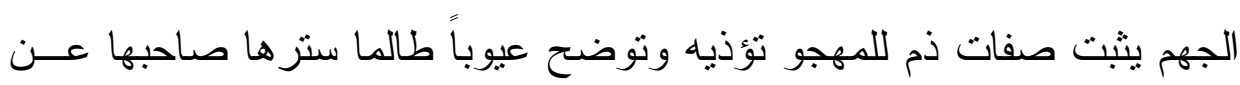

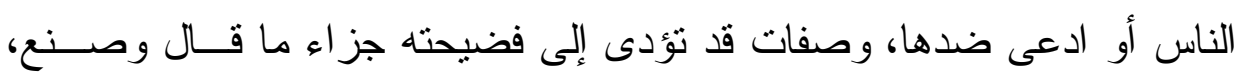
و هى صفات تبقى على مر العصور لورودها فى شعر يروى ويدون ويتتدر بـــه

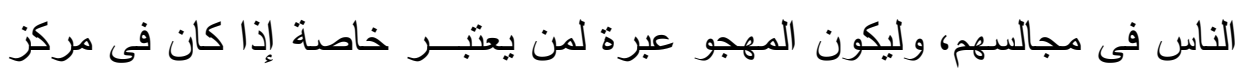
ومنزلة كبيرة كقائد أو وزير؛ ومن هذا اللون هجاؤه الوزير "محمد بن عبدالملك ئك

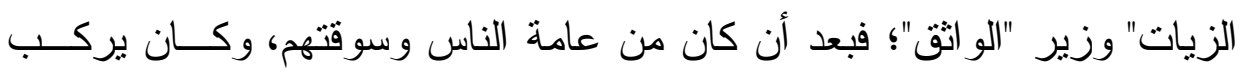
الطوف فى الفرات لصيد السمك، وكـان يبيع الزيت بالحبــات، صــــار وزيـــراً

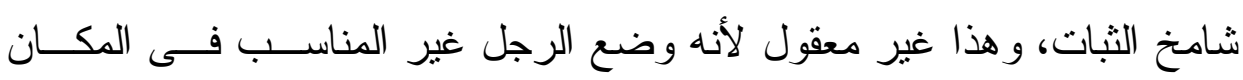

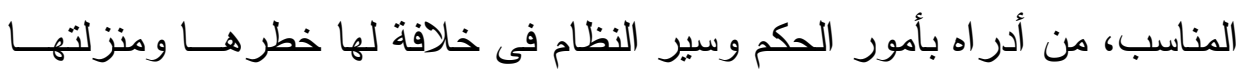

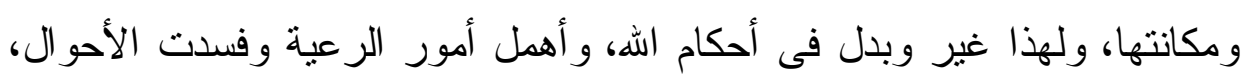
و الثاعر يرصد كل هذا بعينه الباصرة وذهنه الثاقب فقام بدوره يهجوه وينـادى وماد

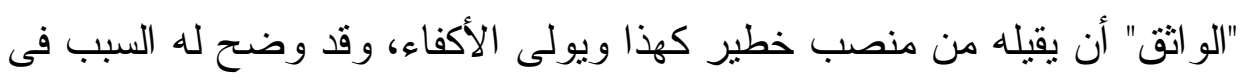
ثوب الهجاء مستتز لاً اللعنات عليه صباح مساء".

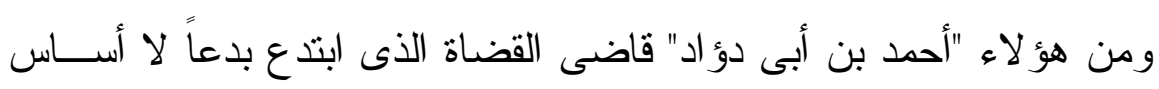

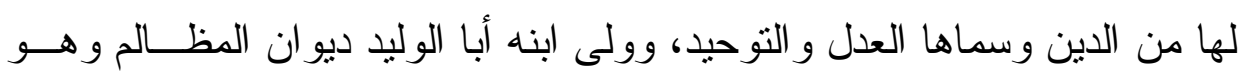

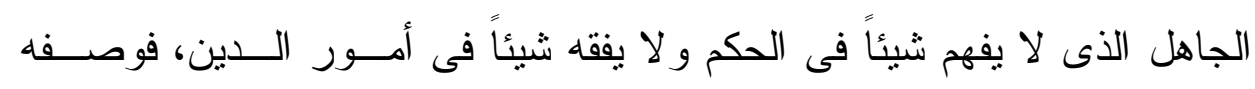
بصفات ذم كثيرة، ودعا عليه فضم ذمه إلى ذم أبيه فى قصيدة و احدة. وقد هجا قوماً عربدو ا عليه بهجاء وسمهم به ليفضحهم على رعوس الناس؛

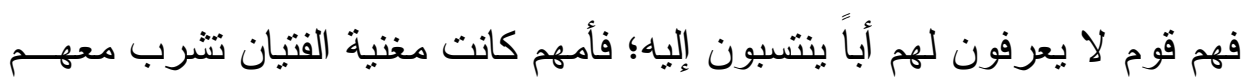

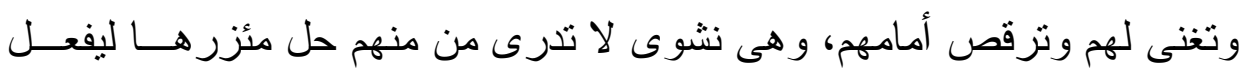

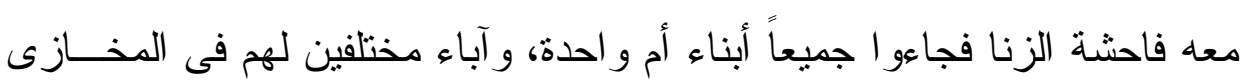


تاريخ لو تفكرو ا فيه ما عابو ا غير هم أبداً، و لا تعرضو الهتك أعــر اض الكــرام أمثاله.

و هؤ لاء هم جلساء "المتوكل" وندماؤه الذين كادوا لابن الجهم حتى أصـــابه ما أصابه من السجن و النفى وغيره هجاهم بأقذع صفات الذم و أقبحها؛ فقد كانو أوهاء

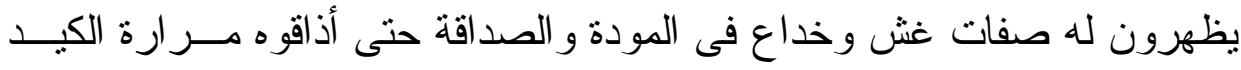

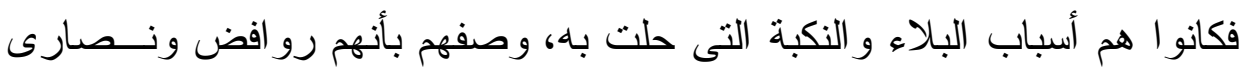

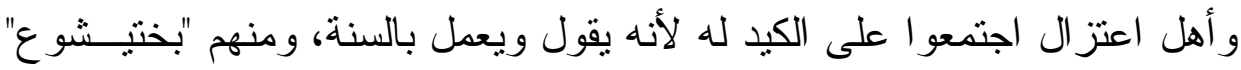

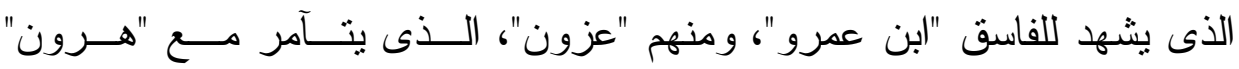

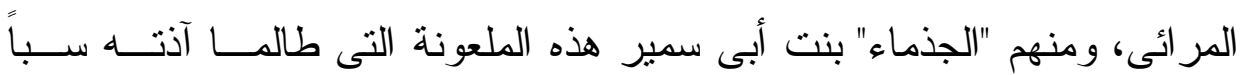

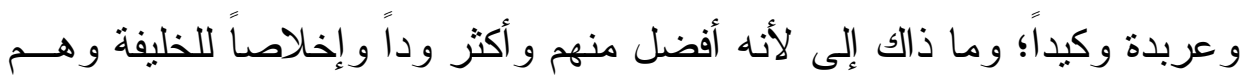

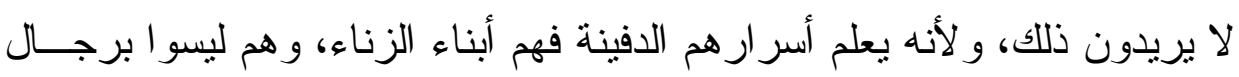
و لا أنصاف رجال؛ بل نساؤهم أفضل منهم، وهم شر من تحت السماء. قال قدامة بن جعفر : ومن خبيث الهجاء ما أنشدناه أحمد بن يحيى أيضاً:

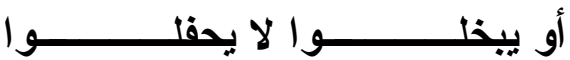

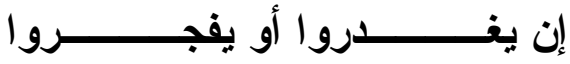

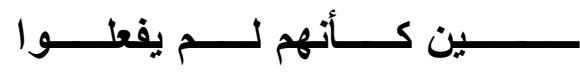

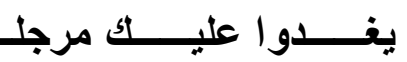

فمن جودة هذا الهجاء أن الثاعر به تعدد أضداد الفضائل علــى الحقيقـــة فجعلها فيهم لأن الغدر ضد الوفاء والفجور ضد الصدق و البخل ضد الجود، ثـم

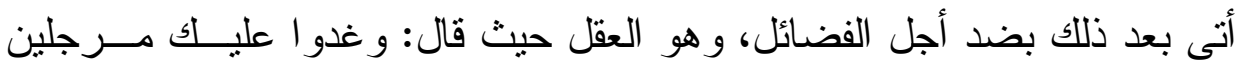
كأنهم لم يفعلوا، لأن هذا الفعل إنما هو من أفعال أهل الجهل و البهيمــة و القحـــة 
التى هى من عمى القوة المثيرة كما قال "جــالينوس" فــى كتابـــه فــى أخــاق (النفس (') - (1)

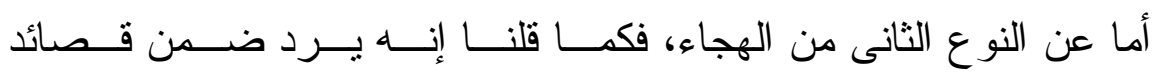

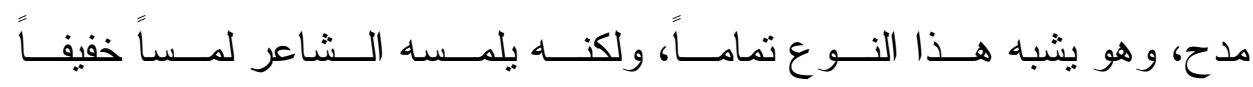

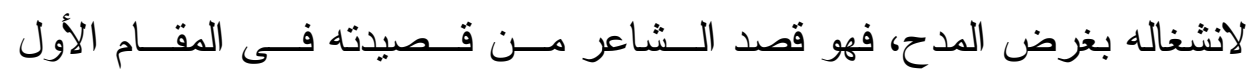

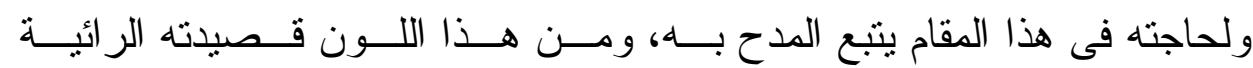
التى يمدح فيها "المتوكل": "وقائل أيهما أنور"؛ وفيها وفيها يقول:

مـن معسشر مــا مــثلهم معسشر

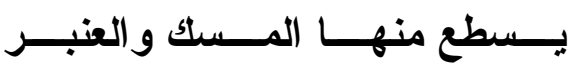

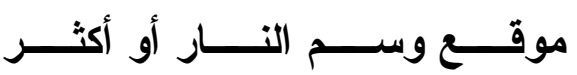

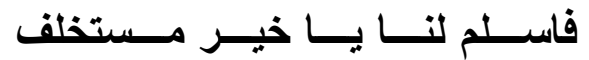

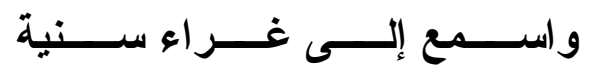

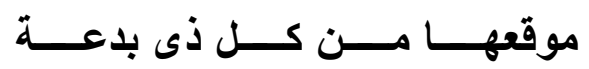

قالها يمدح "المتوكل" وفيها يذكر أنها تقع سمة ذل و عار كوســم النــار أو

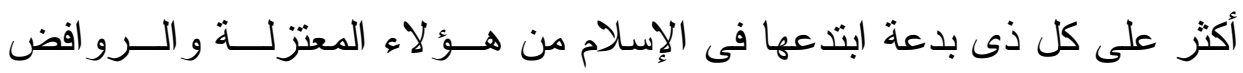

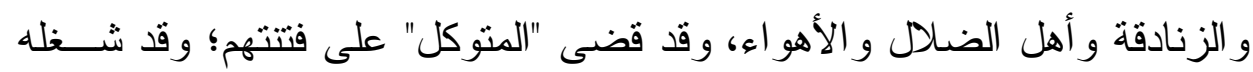

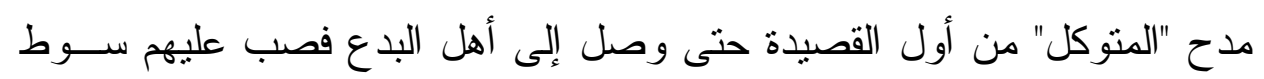

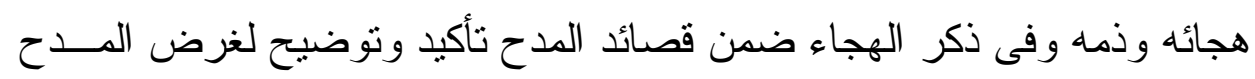
وتقوية له. وسيأتى توضيح ذلك فى الدر اسة الفنية بمشيئة الله تعالى.

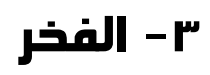

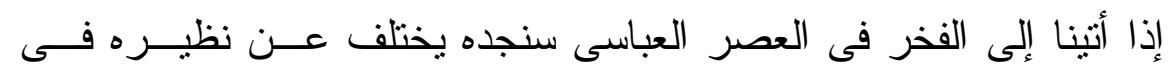

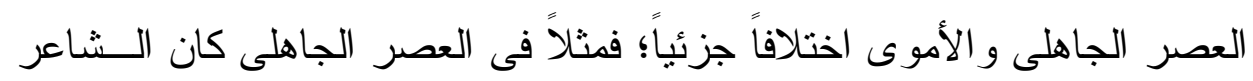
يفخر بقيلته وما أحرزته من نصر على القبائل الأخرى و استيلائها على منــابع 
الماء ومنابت الكلأ، أو أخذاً بثأرها لدمائها ودياتها، وقو افلها التجارية مثناً. وفى

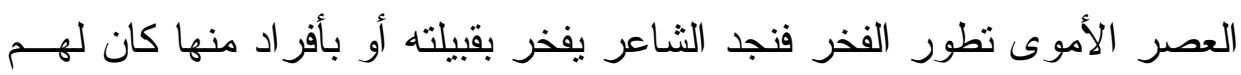

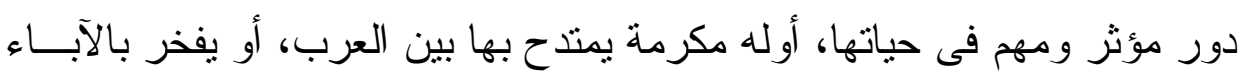

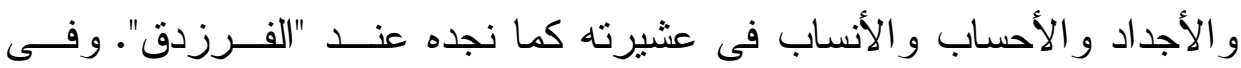
العصر العباسى نجد "أن شعر الهجاء المنبعث عن العصبيات القبلية خفت حدتــهـ

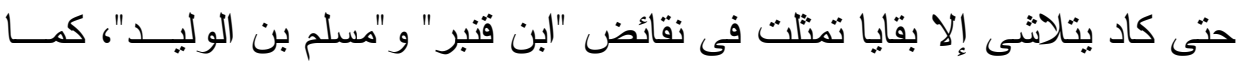
تمنلت فى نقائض "دعبل"، و "أبى سعد المخزومى"، ويرجع ذلك إلى تطور و اسع

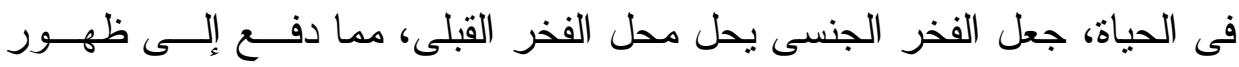

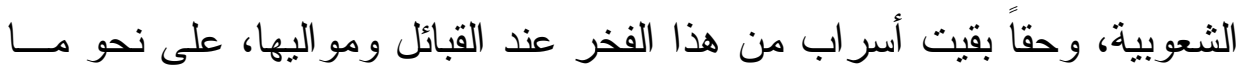
نجد عند "بكر بن النطاح الحنفى"(') فى مثل قوله مفتخر اً بقبيلته "بكر":

ومن يفتقر منـــا يعـش بحسـامه ومن يفتقز من سائر الناس يـسأل وكان "أبونو اس" يفتخر بمو اليه من القحطانيين افتخار اً حاداً، ولكن الدولــة كانت له ولبكر و أمثالهما بالمرصـاد؛ فقد حبس "الرشيد" "أبانو اس" بسبب إحيائــهـ

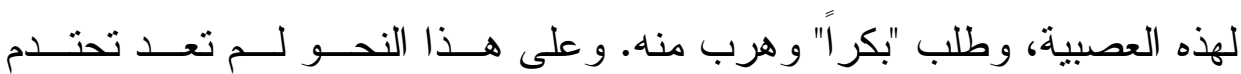
العصبيات وبالتالى خبت نار النقائض التى كانت مشتعلة فى عصر بنى أمية"(؟).

هو أبوو ائل بكر بن النطاح الحنفى شاعر غزل من فرسان بنى حنيفة من أهل اليماهـــة

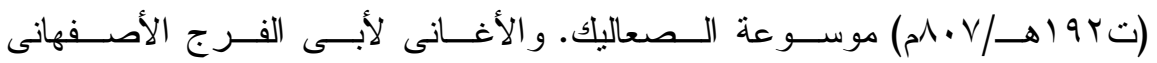
$.10 \cdot 119 \rightarrow$

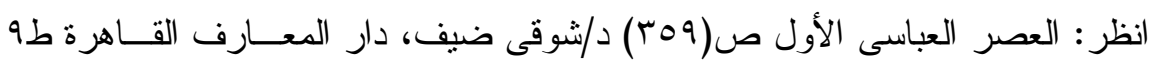

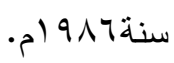


و الجديد حقاً فى الفخر لهذا العصر أن كثيراً من الـشعر اء صــدروا فـى

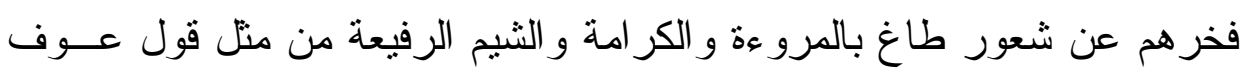

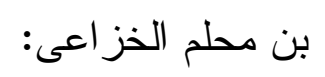

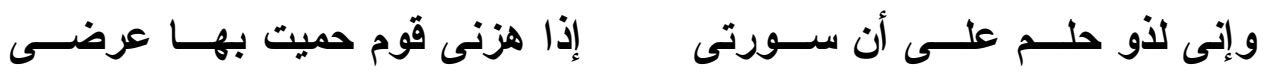

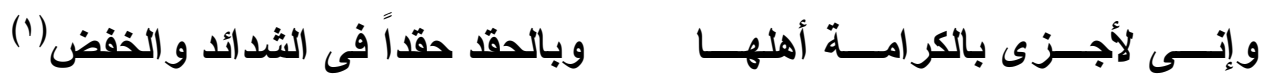

و إذا أتينا إلى عصر خلافة "المتوكل" نجد أن "على بن الجهم" فى فخره قد

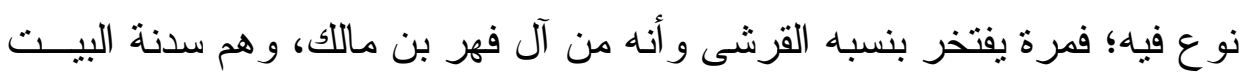

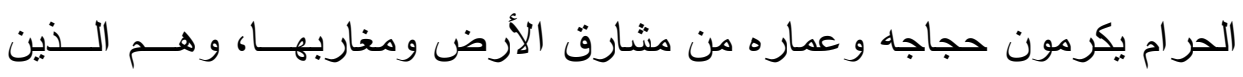

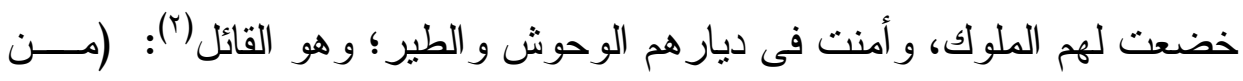
(الكامل)

أيــن النبــوة والقــضـاء الفاصـل بيض الصوارم والوشـيج الــــابل

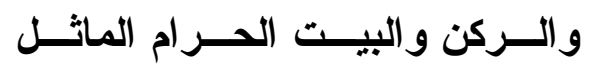

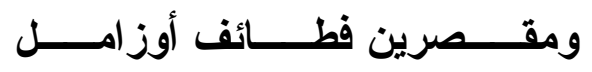

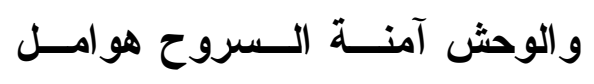
يجلو العمى عنـــه اللبيــب الــسائل

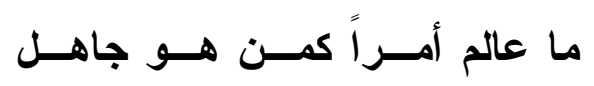

إن كنت جاهلــة بقـــومى فاســألى

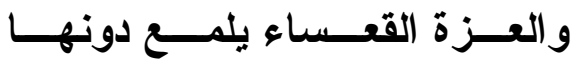
أين المنــابر والمـشاعر والــصفا

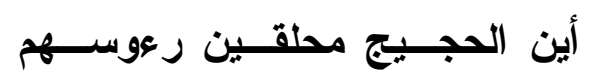

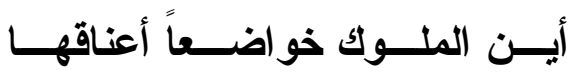

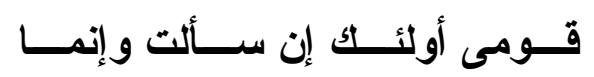
الله يعلــــم حيـــث يجعـــل أمــــره

$$
\begin{aligned}
& \text { انظر : السابق ص ( ( V.). } \\
& \text { انظر : الديوان ص (ع人) ( ). }
\end{aligned}
$$


ففى قومه نزلت رسالة السماء، فكانو ا على مستوى هذه المسـسئولية لأن الله

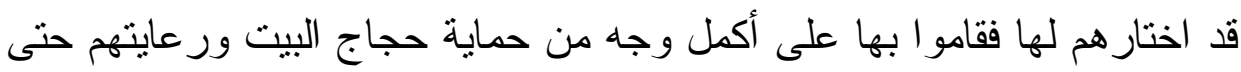
عودتهم إلى بلادهم و أوطانهم بعد أداء مشاعرهم كاملة، وقومه يعلمون الجاهــل

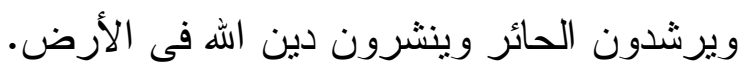

وهو القائل ('). (من الطويل) فى قصيدته الر ائية: "صبرت ومثلــى صــبره ليس بنكر" بعد أن افتخر بنفسه وبما صنع، يفخر بقومه ويرد الفضل إليهم: وتلـــك ســـايانـا قـــيماً وحادثــاً: بها عرف الماضى وعـز المــؤخر

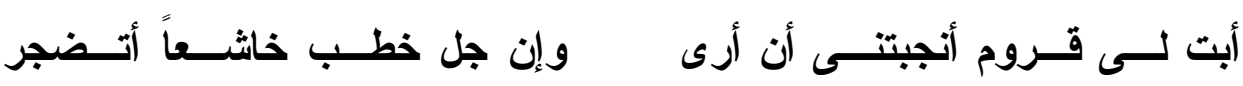

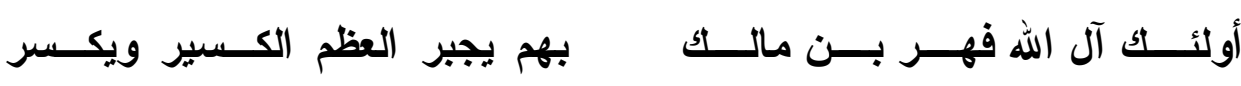

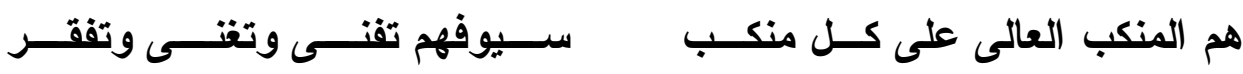
فهو أبداً لا يخاف ولا يخشع لذل ولا يخضع لهوان أو فر ار مــن الميـــان

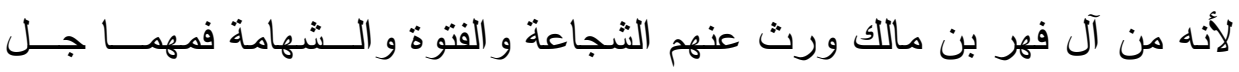

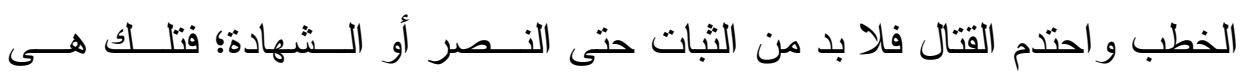
سجاياهم من قديم فهم السادة و القادة يجبرون كسر الــضعيف المـستجير بهــم، ويكسرون عظم المتجبرين الطغاة فسيوفهم تفنى وتغنى وتفقر من تشاء. وهو القائل مفتخر اً بقومه، وكيف أنهم من أهل خر اسان أثنياع بنى العباس، و هم أولو قوة وبأس شديد، يؤيدون خلافتهم وحقهم فيها؛ فرضاهم حق عليهم، لا

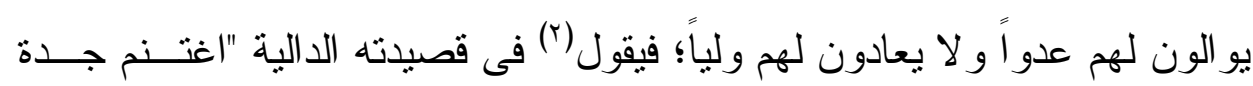
(من الخفيف)

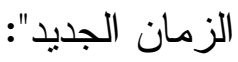

$$
\text { انظر : الديوان ص (9 (1)). }
$$




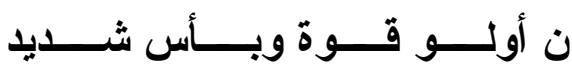

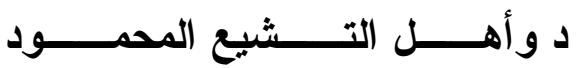

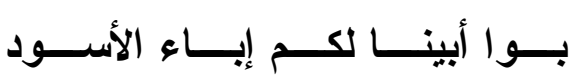

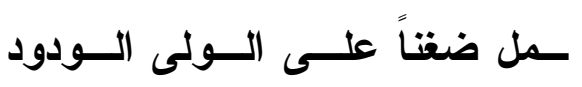

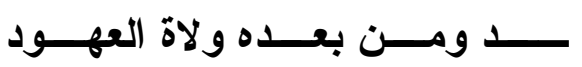

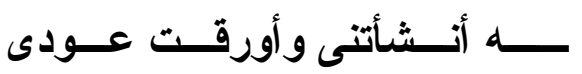

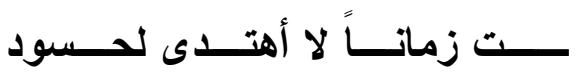

نحن أثثياعكم مــن أهـل خراســا

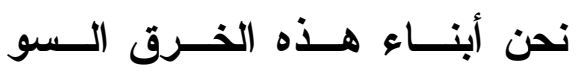

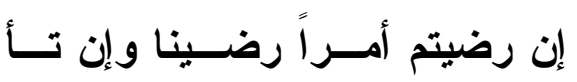

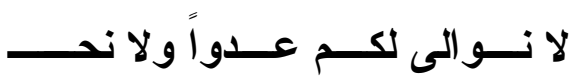

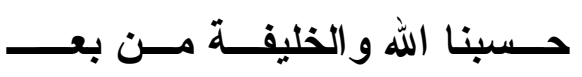
غرس كفيك يابن عم رسول اللـــ

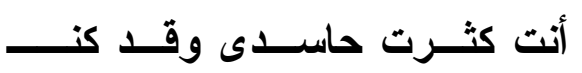

يفتخر بما صنعه قومه من أهل خر اسان مع بنى العباس من إقامة دوبـتـهم، و المشاركة فى القضاء على دولة الأمويين، وتأييدهم فى هذا الحق دون غيـــرهم فهم أولو الأرحام بنص القرآن الكريم فى سورة الأنفال.

ونجد "على بن الجهم" يفخر بنفسه وبما صنع وتحمل كما فخر بقومه مــن

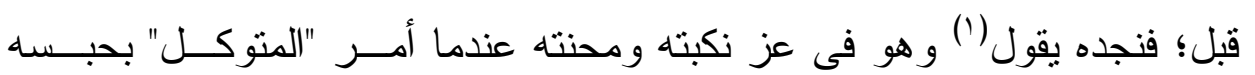
وسجنه بسبب ما سمعه من ندمائه عن "على بن الجهم" فأوغرو ا صدره ضـــــــ وهوه يقول:

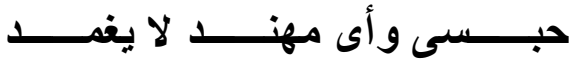

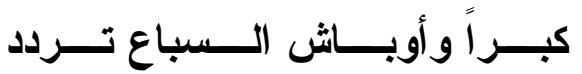

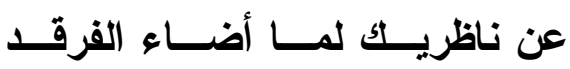

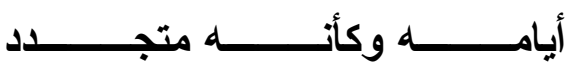

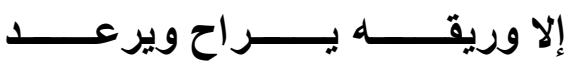

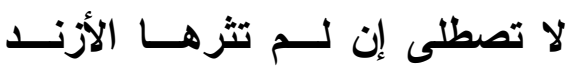

قالت حبست فقتـــت لــيس بــضائر أو ما رأيســت الليــث يــألف غيلـــهـ والــشمس لـــولا أنهــــا محجوبـــة

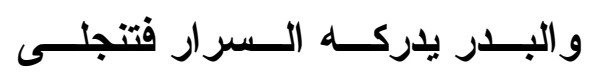

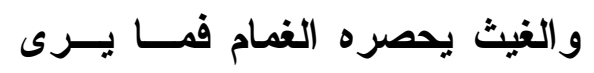

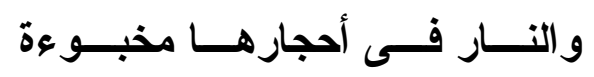




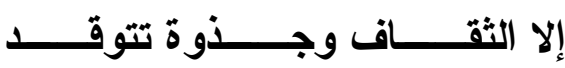

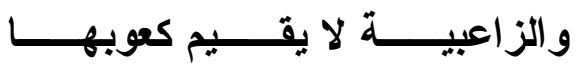

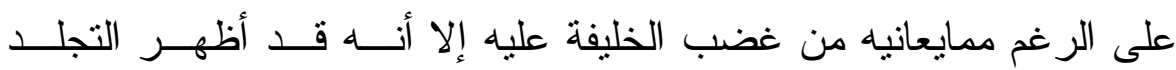
و التماسك؛ لأنه يعلم مدى تأثير الندماء عليه فى اتخاذ كل قرار ضده مما افتروه

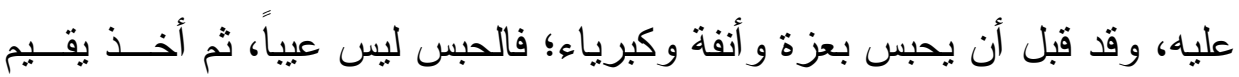

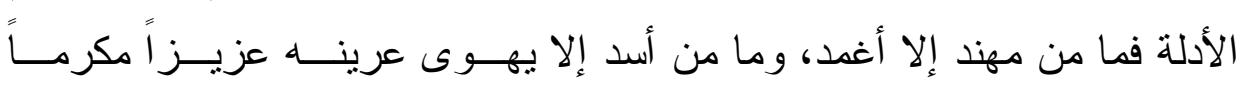

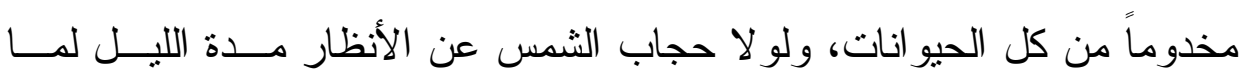

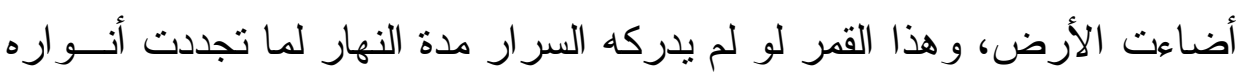
ولما أضاءت لياليه، و هذه النار لو لا أنها مدخرة للعباد فى أحجار ها يـستخدمونها عند الحاجة لأحرقت كل شىء، وهذه السهام التـى تــصيب الأعــــاء بــالموت و الهالك أقيمت كعوبها بالتقاف و النار الموقدة. ثم يقول فيها أيضاً:

شــنـعاء نـعـــم المنــزل المتـــورد

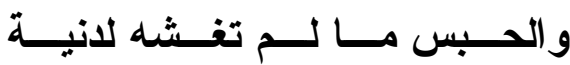

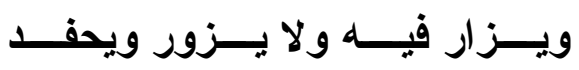

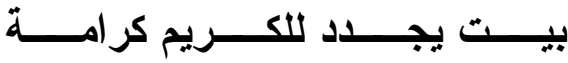

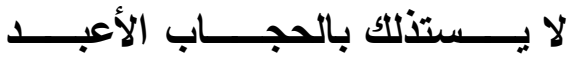

لولم يكـن فـــى الــسجن إلا أنـــه

فالحبس ليس ذلاً و لا إذلالاً للكريم الذى دخله ظلماً دون ذنب؛ بل هو بيت

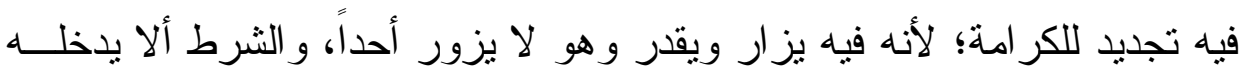

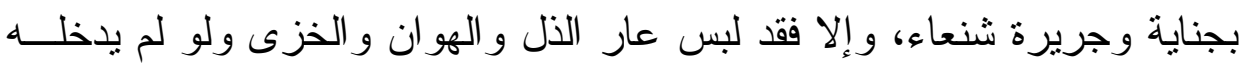
محبوساً.

ومما قال فى الفخر بنفسه قصيدته اللامية: "لم ينصبو ا بالثشاذياخ"؛ بعـــ أن أمعن له الأعداء فى الكيد لدى "المتوكل" أمر أن يقيد فى حبسه فقيد؛ فقال: 


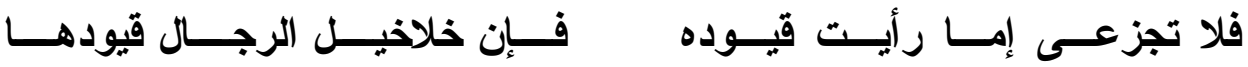

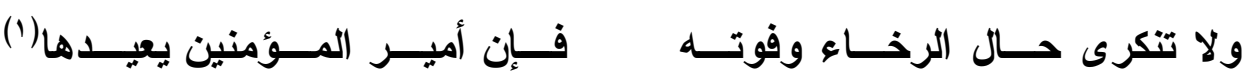
ثم ز اد الأعداء به كيداً، فأمر أن بنفى إلى خر اسان و أمر "طاهر بن عبداله"

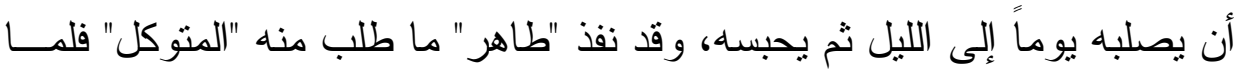
صلب "على بن الجهم" صلب مجرداً من ثيابه، ثم أنزل آخر اليوم وحبس فقــال (من الكامل) (م)

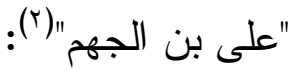

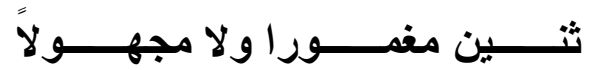

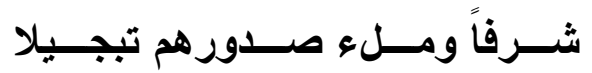

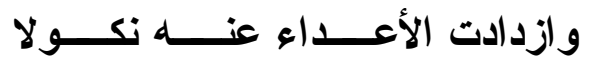

فر أيتــــه فـــى محمـــل محمـــــلا

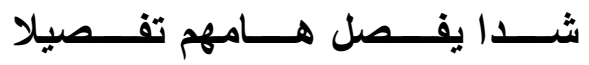

فالسيف أهول مـــا بـرى مـسـلولا

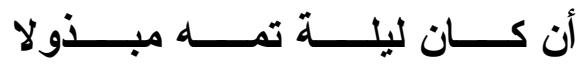

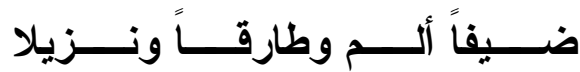

مــن شـــره يـــــ العزيــز ذلــيلا

نعـــم و إن صـــعبت عليـــه قتــيلا

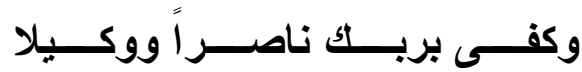

لم ينصبوا بالسـشاذياخ صــبيحة الإ نصبوا بحمـــ الله مـلـع عيـونهم مـــــا ازداد إلا رفعـــــة بنكولــــــهـ هل كــان إلا الليــث فــارق غيالـــه

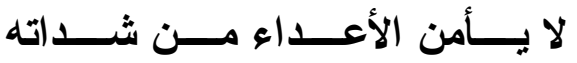
مــــا عابـــــه أن بزعنـــــهـ ثيابـــــهـ

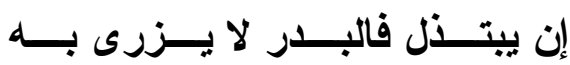

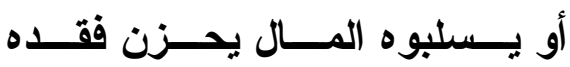
أو يحبسوه فلـيس يحـبس ســائر

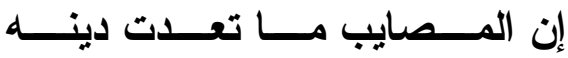
والله لـــيس بغافــل عــن أمــــره

المنصوب ليس شبحاً كغيره من الناس؛ بل هو الثرف و الأصل و النجابــة

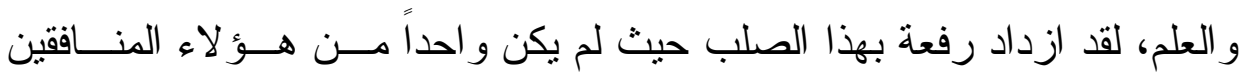

$$
\text { انظر : الديو ان ص (Y (I)). }
$$


المخادعين الذين يضمرون خلاف ما يظهرون و الذين دسو ا عليه ما لـــبس فيـــ فأحدثو ا الفرقة بين الصديقين، ولم تخطر لأحدهما على بال فقطعو ا من الود مـــا

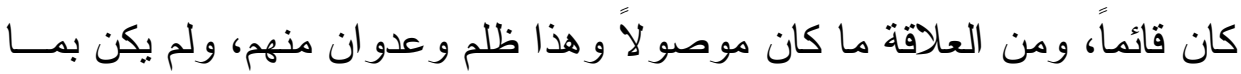

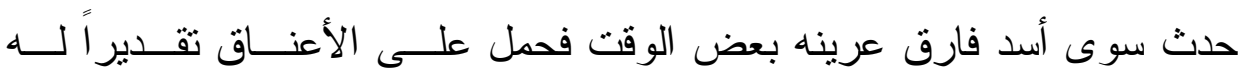

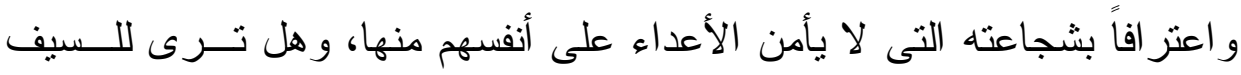

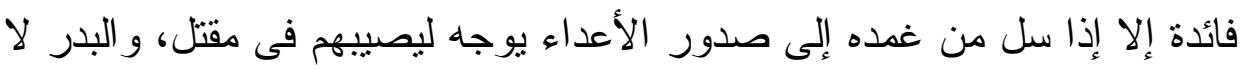

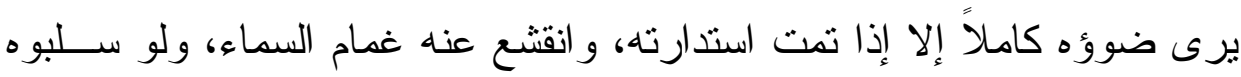
ماله لا يحزن عليه، و إن يحبسوه فلن يحبسو اشعره الذى ستسير بـــه الركبــان

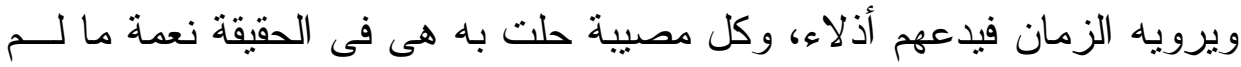
تكن فى دينه، و الله يعلم كل ما صنعوه وكفى به ناصر اً ووكيلاً. ثم يضيف قائلاً:

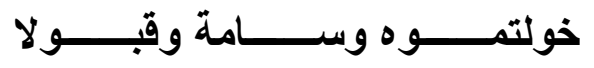

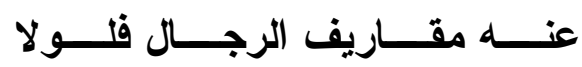

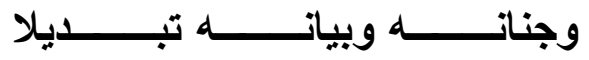

ما الــنقص إلا أن يكــون جهـولا

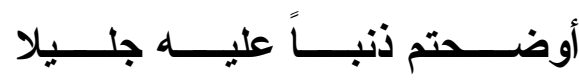

غير الجميل مــن الأمسـور جمـيلا

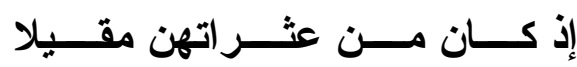

عنها الأكنــة مــن أضــل ســبيلا
لن تـسلبوه و إن ســلبتم كـلـ مـــا

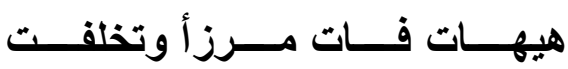

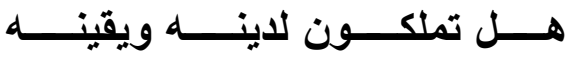
لم تتقــصوه وقــــ ملكــتم ظلمـــهـ كادت تكـون مــصيبة لــو أنكـم إن كان سف إلــى الانيئـــة أو رأى

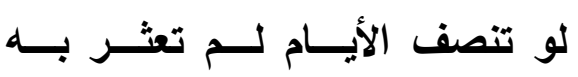

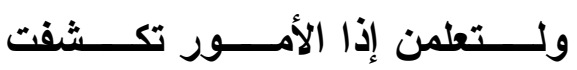

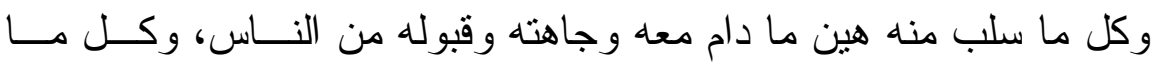

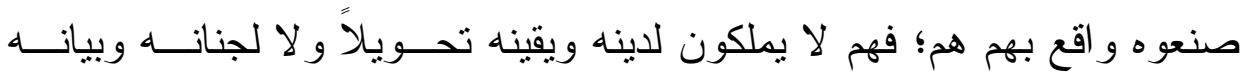

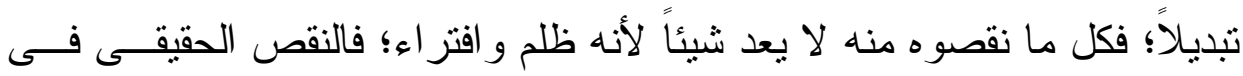

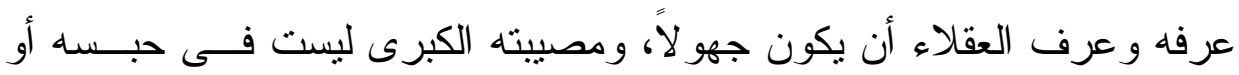


الكيد له؛ بل هى أن يتزدى فى ذنب أو فاحثة، أو يرى غير الجميل جميلاً، وما

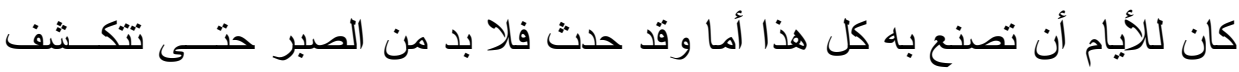
الستور وتتضح الأمور فسيعلمون من أضل سبيلاً. ومما قال فى الفخر بنفسه ما ورد فى قصيدته المشهورة: "عيون المها بين

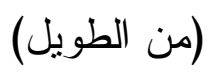
الرصافة و الجسر "؛ يقول(') - (')

صلى واسألى من شئت يخبرك أننى على كل حال نعم مستودع السر (؟)

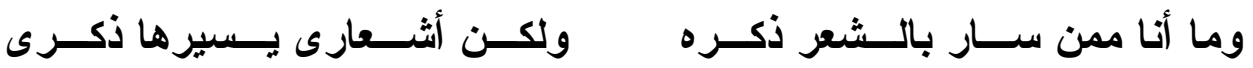

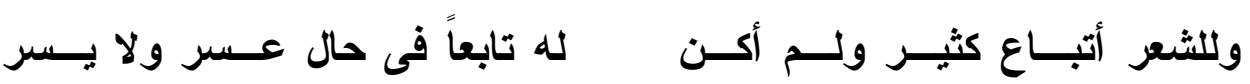

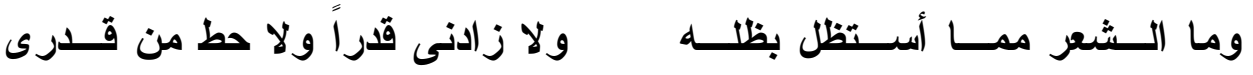
ولكـن إحسـان الخليفــة "جعفـر" دعانى إلى ما قلت فيه من الـشعر فسار مسير الثمس فى كـلـل بلــدة وهب هبوب الريح فى البر والبحــر ولو جل عن شكر الــصنيعة مــنعم لجل أمير المــؤمنين عــن الـشكر

إنه الأمين على كل سر؛ لا يفشى سر صديقه و لا سر عدوه، وقليـلـ مــن الناس من يصنع ذلك، وهو فى ذللك يختلف عنهم، ويختلف عــن زمالأُــه مــن

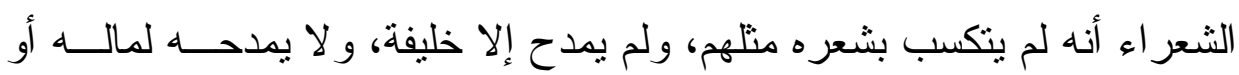

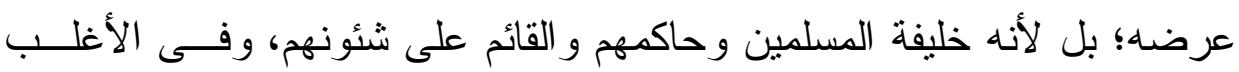

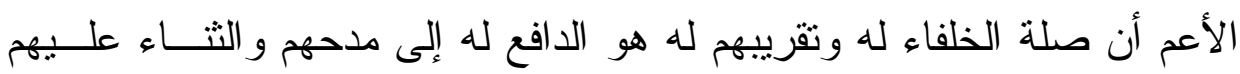

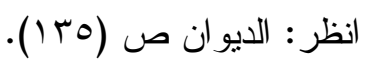

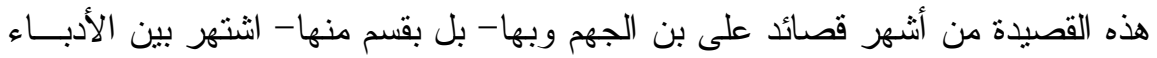

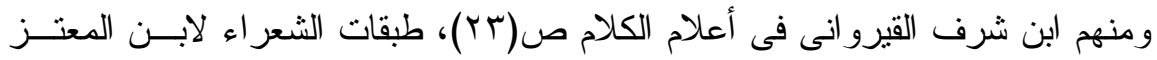

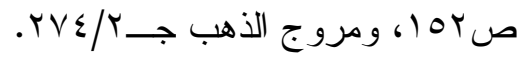


بشعر لم يصنعه إلا مكافأة لهم على هذه الصلة، وجز اء على هذا التقريب، فلــم

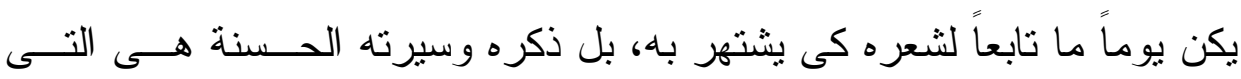

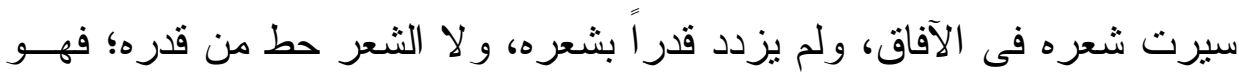
منشئه وناظمه ومنشده.

ومن فخره بنفسه بعد خروجه من الحبس ورجو عه إلــى بغـــداد، و علمـــهـ

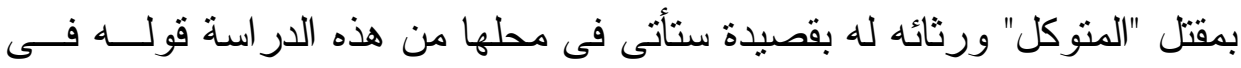
رائيته: "صبرت ومثلى صبره ليس ينكر ولــيس علـى تـــــ الــتفحم يعـذر.

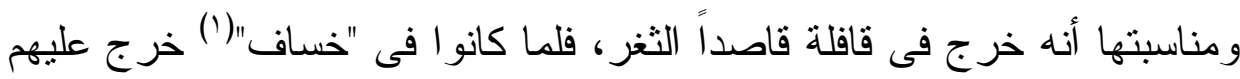
نفر من الأعراب الكلبيين، فهرب من كان فى القافلة من المقاتلة، وثثبت "علـى

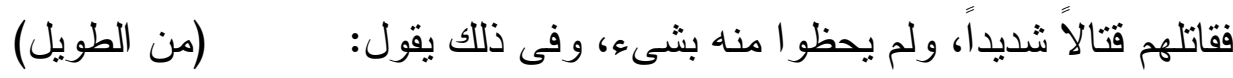
صبرت ومثلى صبره لــيس ينكـر وليس علـى تـرك الـتقحم يعـذر

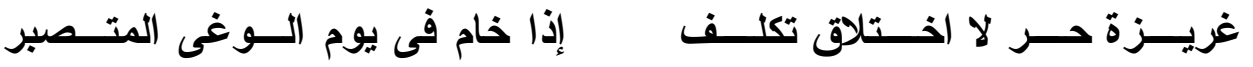
ولما رأيت المــوت تهفـو بنـوده وباتت علامــات لـــه لــيس تنكـر

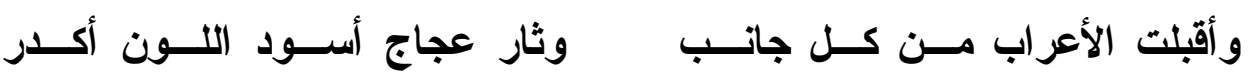

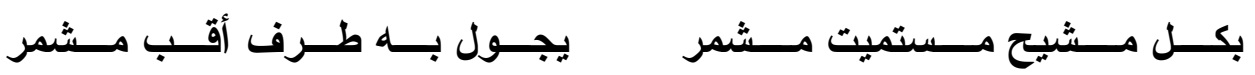

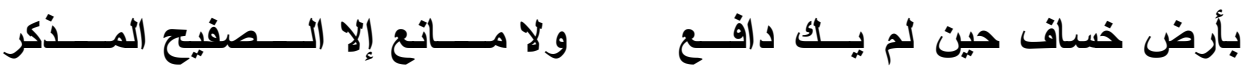

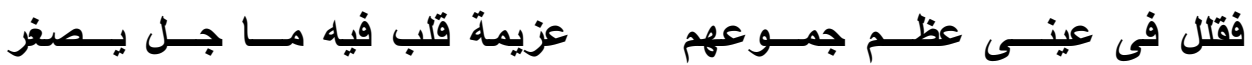

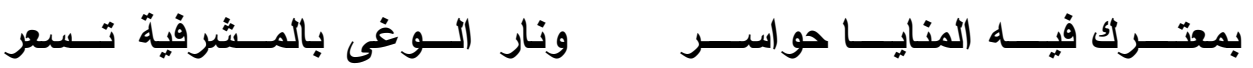
فما صنت وجهى عن ظبات سيوفهم ولا انحزت عــنهم والقتــا تتكـسر ولم ألى فى حـر الكريهـــة محجمــاً إذا لم يكن فى الحرب للورد مصدر

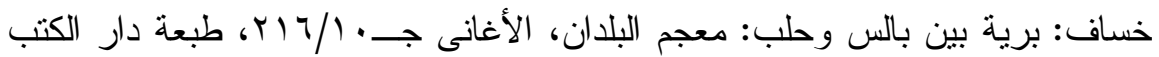

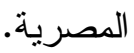


صبر على قتال الأعر اب رغم فرار المقاتلة الذين كانو ا معه، فلم يفر مثلهم لأنه ما تعود الفر ار من الميدان، و لا يعرف ذلك فى نفسه فأخلاقه لا تسمح له أن يفر ، وقد ر أى الموت يقترب منه، و الأعر اب يأتون إليه من كل مكان قاصــدين قتله، وكانت عزيمة قلبه و إيمانه هى التى قللت جموعهم فى عينيه فأقبل علــيهم

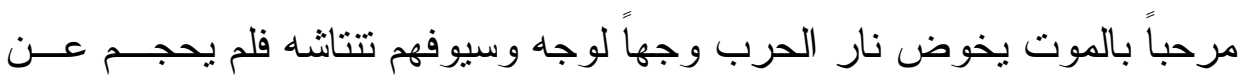

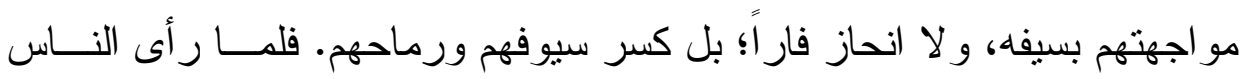
شجاعته ومثنابرته ثابو إليه فدفعهم، ولم يحظو ا بشىء منه؛ يقول:

إذا سـاعد الطــرف القتــى وجنانــهـه وأســـمر خطـــى وأبــيض مبتـــر

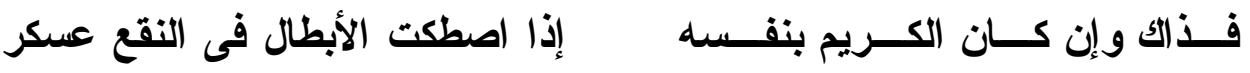

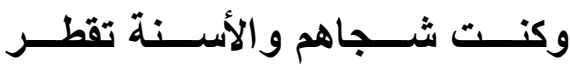

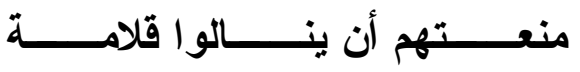
إن عدة المقاتل هى العقل و الفرس و الرمـح و السيف و الهمـــة و الــشجاعة، وبهذه كلها استطاع أن يهزم أعداءه، فصاروا يتحدثون عن شجاعته، فلما كـان من غد خرج على القافلة منهم خلق كثير، فتسرعت إليهح المقاتلة، وخرج "على" فيهم فأصابته طعنة قتلته.

أما عن خصائص الفخر فى شعر على بن الجهم؛ فمنها ما هو خــاص إذا

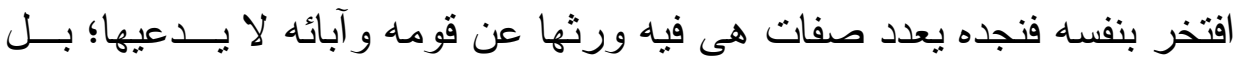
يعددها صـادقاً؛ فلم يعرف فى حياته سوى الصدق الذى تطمئن له نفسه؛ تحمـلـل

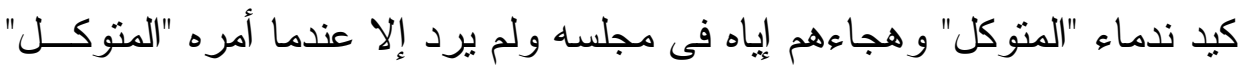

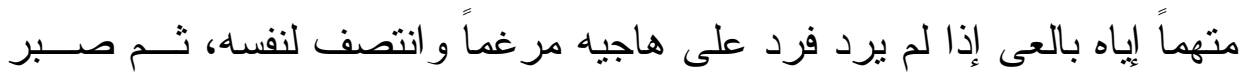

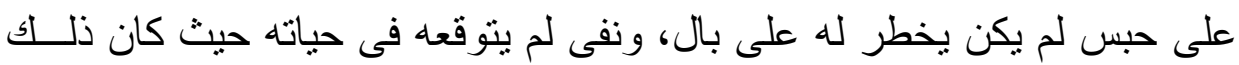
بأمر صديق حبيب مقرب إلى نفسه هو الخليفة "المتوكل" ثم صلب ثم حبس، فهو 
يفخر بذلك كله لأن له إر ادة صلبة و عزماً قوياً؛ فما من سيف إلا أغمد، وما من

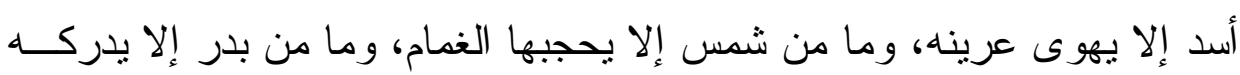

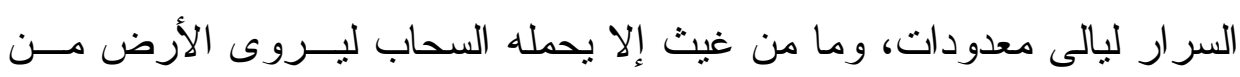
جديد (')

ويفخر بأنه لم يسجن فى جريمة أو ذنب يغضب ربه، ولــــ يحـزن علــى

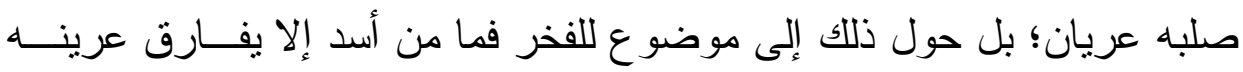

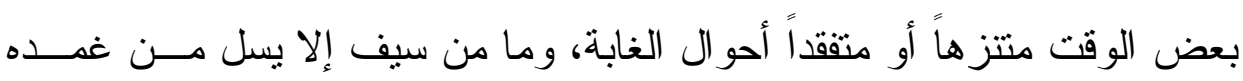
ليوجه إلى صدور الأعداء دفاعاً عن دين الله، وذوداً عن الحمى، و لا يذم البــدر

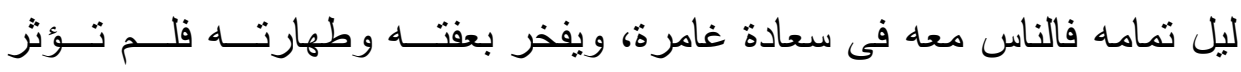

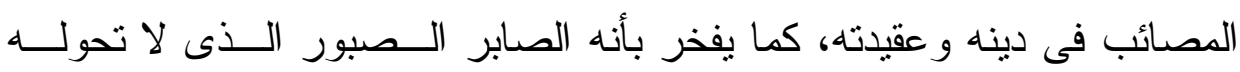
المصائب عن مبادئه التى آمن بها؛ فكل مصيبة دون الدين هى نعمة لــهـ يـشكر

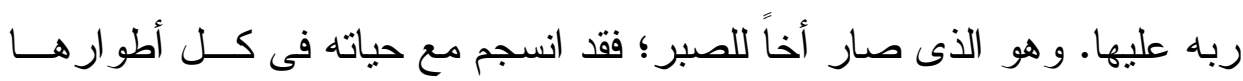

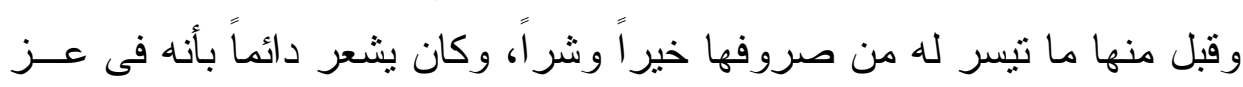
نفسى و اطمئنان قلبى.

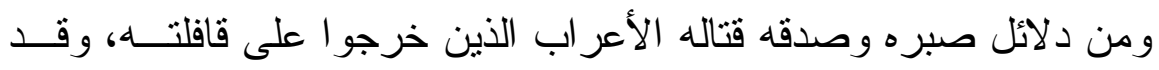
رأى الموت بعينه يدنو منه فصبر وقاتل، ويعلن بأنها غريزة حر وطبيعة فيه؛ لم

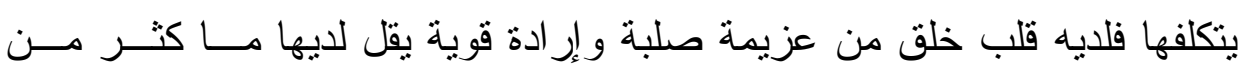
الأهو ال ويصغر ما كبر من المصائب؛ فلم يفر منهم لأنه ما تعــود الفــرار و لا لا يعرفه، وقاتلاهم فى صبر حتى قنل. 


\section{الأستاذ الدكتور / السيد نتح الله عبد العزيز غزالة}

وهو الذى تغنيه شجاعته عن فقره؛ فهو دائماً فى مقدمة الصفوف، وهو لم

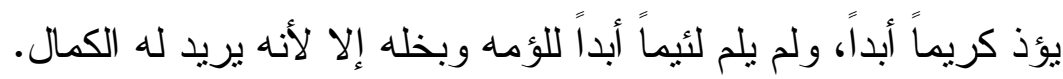

ومن صفات الفخر لديه ما هو عام، وذللك عندما يفخر بقومه و اصفاً إيــاهم

بأنهم أهل الله أبناء فهر بن مالك؛ فيهم النبوة و القضاء الفاصل، أهل عزة و أنفـــة وشمح و إباء أهل شجاعة وحماية للبيت الحر ام وحجاجه، ولو لاهم ما حج البيــت

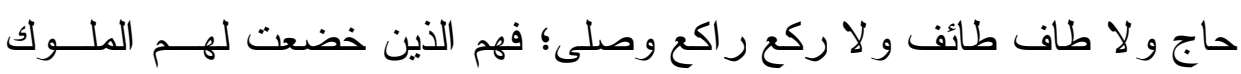
و أمنت فى حماهم الوحوش، وهذا الأمر مرجعه إلى اختيار الله لهم لا يريد مــن ور اء ذلك إحياء عصبية قديمة، ولكن بيين لنا دور هم فى خدمة ديـن اله قــديماً

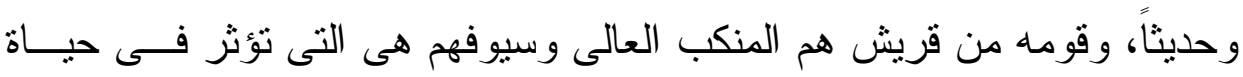

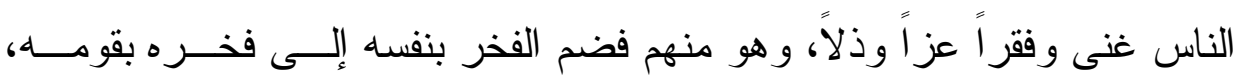

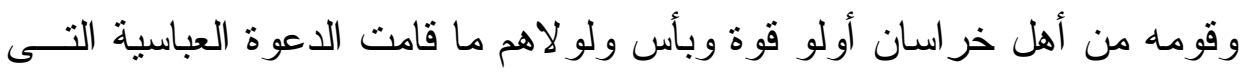
أعزت الإسلام، وخلصت الناس من شر بنى أمية. فما ذكر من صــفات يــدور حول دور قومه و عشيرته فى سبيل عزة الدين، وهذا يشبه ما ذكر من صــفات افتخر فيها بنفسه ذكرناها سابقاً. 
يرتبط الرثاء بالموت؛ فما من حى يرثى؛ بل يمدح؛ أما الميت فيمدح رثنـاء

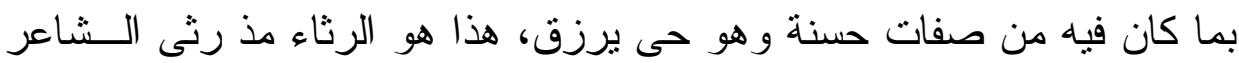
الأول فى العصر الجاهلى، وتلاه نظيره فى العصر الأموى؛ فما من ميت رئيس قبيلة أو أمير أو قائد أو خليفة يموت إلانتى الثعر اء ممن يتصلون إليه بـسبب

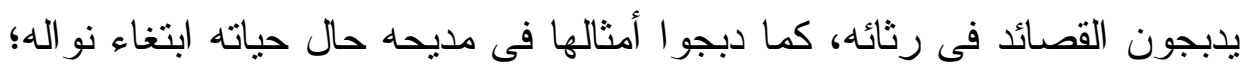

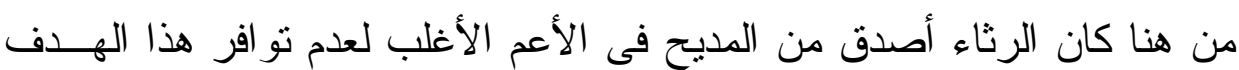
وهو صلة الممدو ح وعطاؤه.

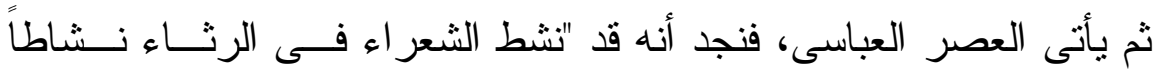

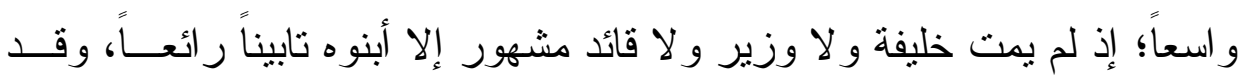
صوروا فى القو اد بطولتهم ومحنة الأمة و الجيوش فى وفاتهم، وكيف ملأ موتهم

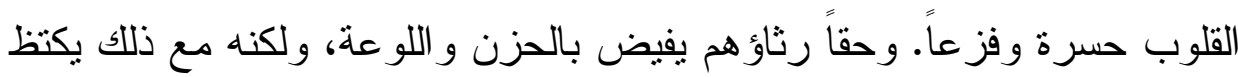

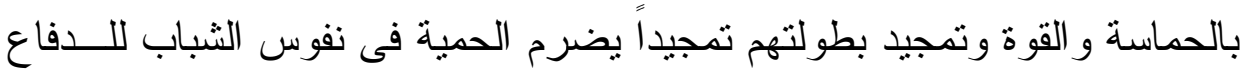

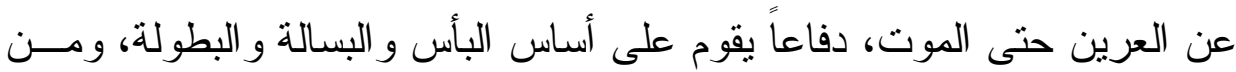
ذللك رثاء "أبى تمام" "لمحمد بن حميد الطوسىى" الذى سقط فــى ميــــان القتـــال

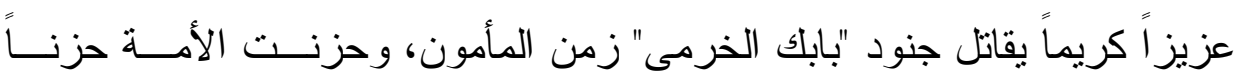

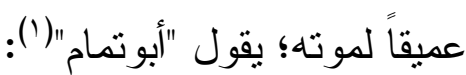
أصم بك الناعى وإن كسـان أسـمعا وأصبح مغنى الجود بعــك بلقعـا أبوتمام هو حبيب بن أوس الطائى الثاعر الششهور ، ولد فى جاسم من قـــى حــوران سنة .9 اهـ، وتوفى بالموصل سنة ابكانهـ. 
(من الطويل) (20) (n)

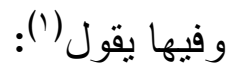

فتى كلما ارتاد الشجاع من الــردى مفراً غداة المأزق ارتــاد مــصرعا

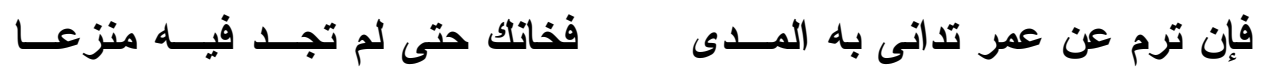

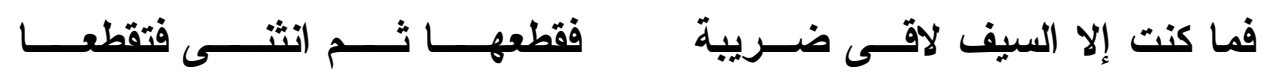
ومن هذا اللون أيضاً رثاء "منصور النمرى" يؤبن "مزيد بن مزيد الثيبانى" الذى فتلك بخو ارج الموصل فتكة لم تقم لهم بعدها قائمة؛ يقول:

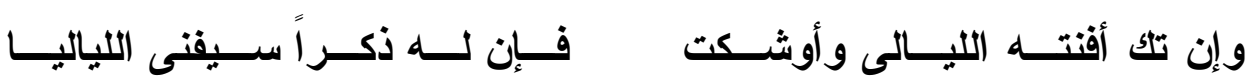
ومنه أيضناً رثاء "على بن الجهم" "عبدالله بن طاهر"(؟) بـن الحـسين ابـنـ مصعب الخز اعى(r) وكان من أثنهر الولاة فى العصر العباسى، ولى الثام مدة،

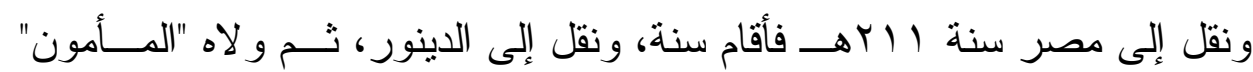

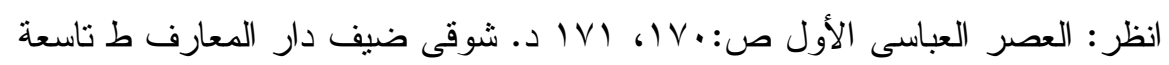
سنة 919 ام. "عبداله بن طاهر" و لاه المأمون مصر و أعطاه مالها العام خر اجها وضــــاعها، فو هبــــ

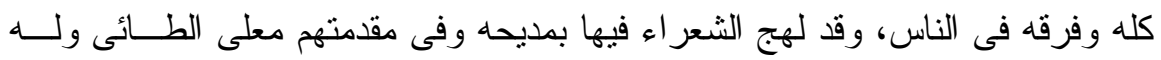
يقول: لو أصبح النيل يجرى ماؤه ذهبا لما أثرت إلى خزن بمثقال

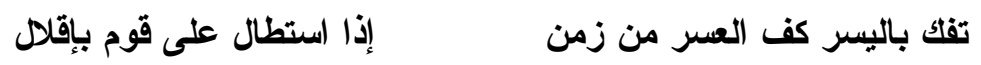

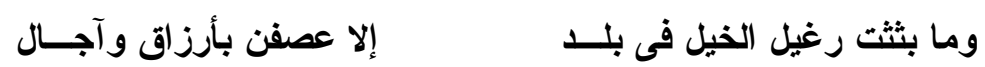

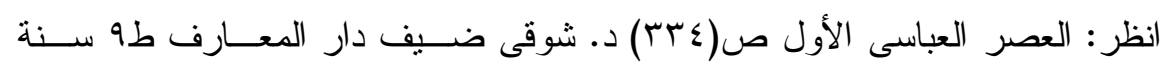

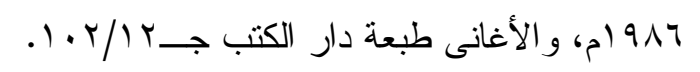




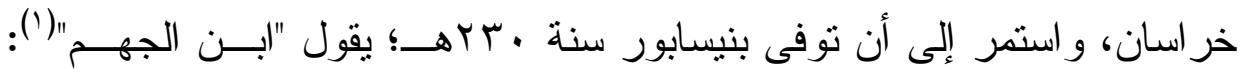

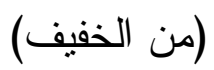

أى يــــوم أخنــــى علـــــى الأيـــــام أى ركــن وهـــــــــن مـن الإســـلام

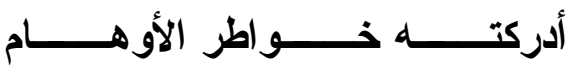
جـل رزء الإمــام عــن كـلـل رزء وأباحـــت حمـــى عزيــز المــــر ام

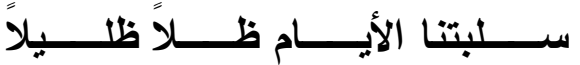
س محــل الأرواح فــى الأجـسـام يا بنى مــصعب حلــتم مــن النـــا عـــم مــــا خــــم جميــع الألـــام شــــــاهدات علــــــى قلـــــوب دوام فــإذا رابكـــم مــن الـــهر ريسـب انظــروا هـــل تـــرون إلا دموعـــاً

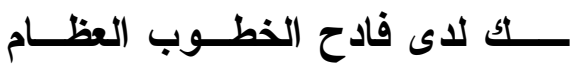
ــطب موت الــسادات والأعــلام

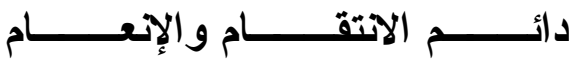

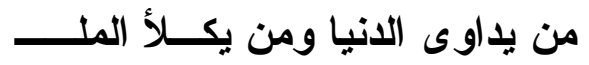

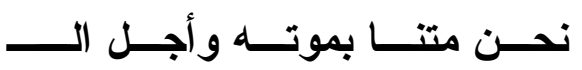

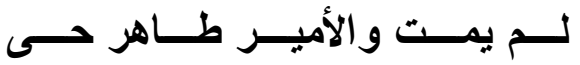
وقـــوام الــــنيا وســـيف الإمــــام وهو مــن بعـده نظــام المعــالى رثاه بما كان فيه من صفات جعلته قائداً مسلماً وو الياً أميناً علــى رعيتــه؛ فيوم أن مات كأن ركناً من الدين قد هوى؛ فقد كان حازماً فى حــدود الله قائمــاً بالعدل و القسطاط؛ أمنت الرعية فى و لايته فكان ظلاً ظليلاً لهم، لقد جل خطـ بـهـ فيه عن كل خطب، وعظم رزء و الدهوخليفته عن كل رزء تتــصوره العقــول، وما ذالى إلا لأن بنى مصعب الخز اعى قد حلو ا من الناس محــل الــروح فــى الجسد؛ فالمصيبة و احدة، و الخطب جلل ومشترك فما خصهم منه عم كل الناس، و الدليل هذه الدموع الغزار التى فى عيون الناس وقد شهدت على حـزن و ألـــم 
عميق ألم بهم يوم فقد هذا العزيز، فقد ماتو ا بموته؛ لأن أعظم المــصائب علـىى الإطلاق موت السادة والقادة والأعلام؛ فهم مصابيح الهدى ور عاة الأمم، ثم يعود الثاعر ويبث الأمل من جديد فى قلوبهم ليصبروا على ما ألم بهم مــن خطــب فادح ومصيبة كبيرة؛ فينفى موته و غيابه عنهم ما دام الأمير "طاهر" أبــوه حيــاً بينهم يؤدى دوره فى حياتهم؛ فهو قو ام الدنيا وسيف الإمام. وشـاع فى هذا العصر بكاء الرفقاء و الأصدقاء، بكاء يفجــر الحـزن فــى

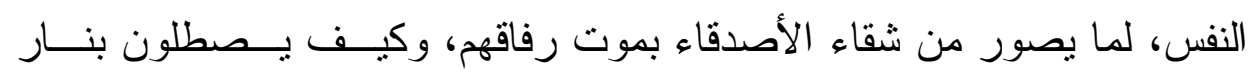
الفراق المحرقة، من مثل قول "بشار" فى ندب أحد أصدقائه من الزنادقة ('):

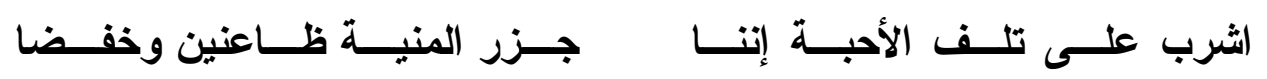

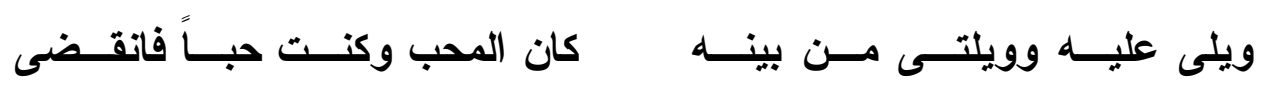

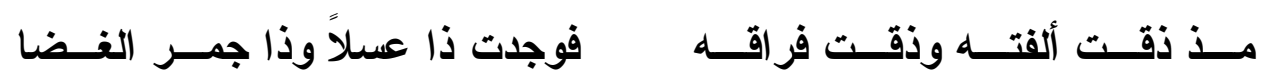
ومن ذلك قول "على بن الجهم" فى "أبى تمام" صديقه يرثيه:

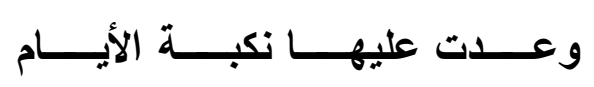

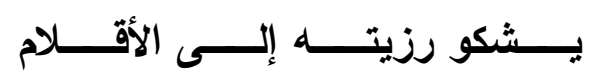

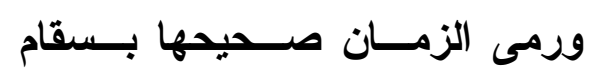

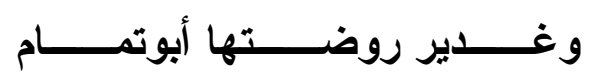

يرثى فيه فطنته التى تفجرت عن بديع شعره ورو عة أدبه، وكيــ عـدـ

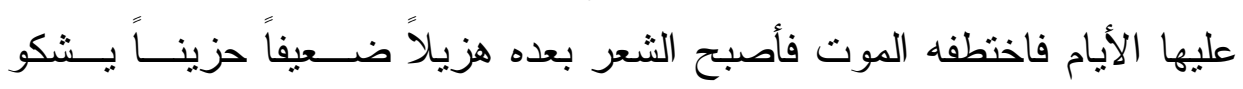

$$
\text { . } 919
$$


مصييته فيه؛ فقد رميت القو افى من بعده فى مقتـلـل فاعتــل صــــيحها وكثـــر

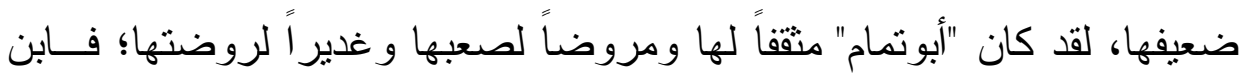
الجهم ينطلق فى رثائه كما ينطلق فى مديحه من دور المرثى و الممدوح فى حياة

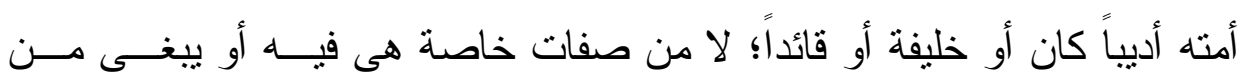
ور ائها مأرباً دنيوياً، و انظر فى قول بشار السابق فقد بكى صديقه بكــاء حـــار اً

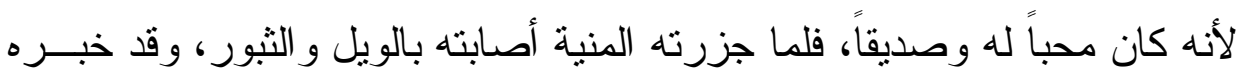
فوجده فى حياته كان عسلاً فلما مات كان نار اً محرقة أصابت كبده. كلها صفات التهات خاصة مشتركة بين الصديقين لا تمت للحياة العامة وللمجتمع بصلة، وبها يـشـار

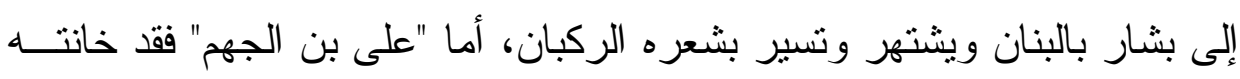

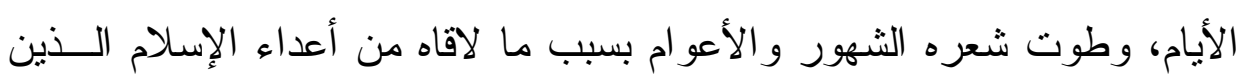

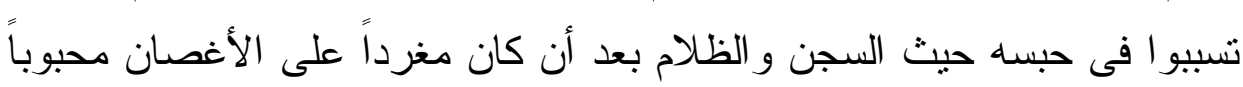
من الأصدقاء و الأقران، لو لا أنها حكمة الرحمن التى قضت عليه ذلك الامتحــــان فصبر وصابر حتى فلك الله أسره وخرج سليماً معافى من حبسه فــى خر اســان لــان

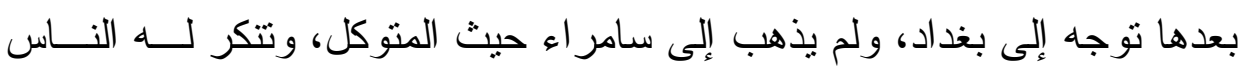

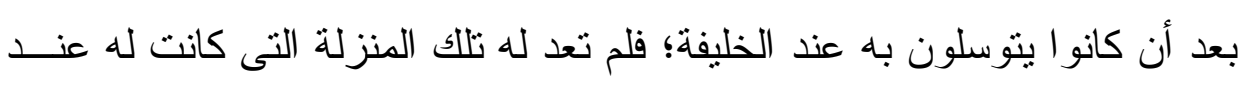

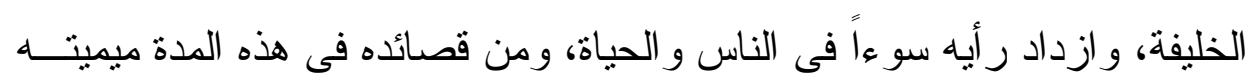

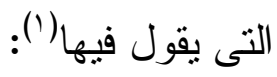

وقت كن من أثـــياعه حيــث يممـــا وأنكــــر إغة إغـــــال العيـــون مكانــــه

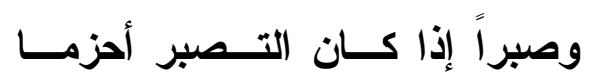
عزاء عن الأمر الــــى فــات نيــــه 
تحول هذا إلى السخر من الحياة والناس، فصاحب أهل الفتوة فــى بغـــداد

$$
\text { يتلهى معهم بالاختلاف إلى بيوت القيان؛ يقول ('): }
$$

نزلنا بباب الكــرخ أطيـب منــزل على محسنات من قيــان المفـضل

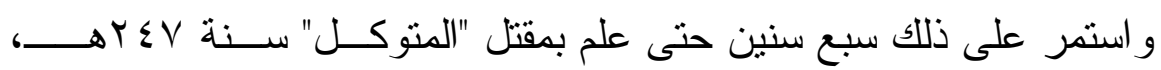

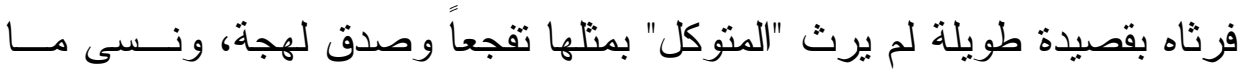

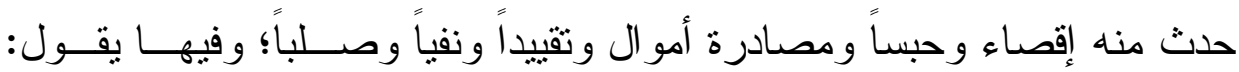

$$
\text { (من الطويل) (من }
$$

شغلت بها عينــاً قـــلاً هجودهـــا

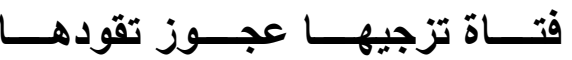

نهتها ولا إن أســرعت تـستعيدها

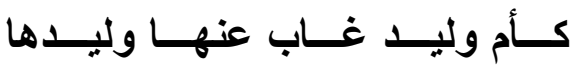

وكادت تــصم الــسامعين رعودهـــا

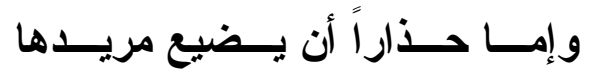

وســارية ترتـــاد أرضـــاً تجودهــــا

أنتنا بهـــا ريــح الــصبا وكأنهــا

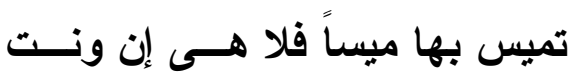

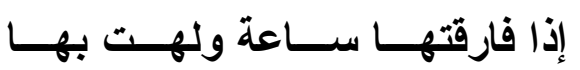

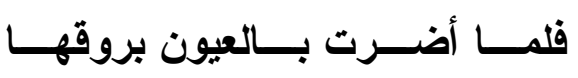
وكادت تميس الأرض إمــا تلهزــاً

وصف سارية (سحابة) حملتها الرياح بما فيها من خير كــادت مــن ثقلــــ

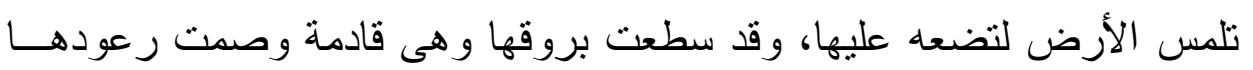

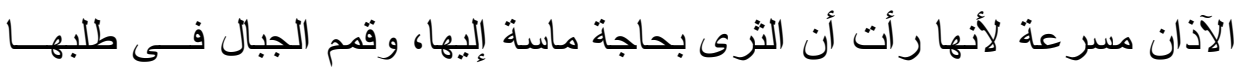

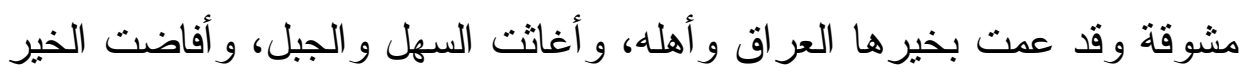

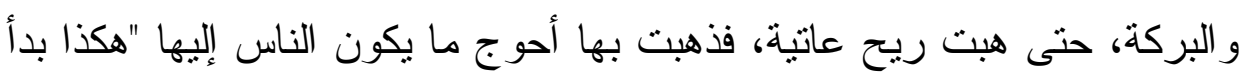

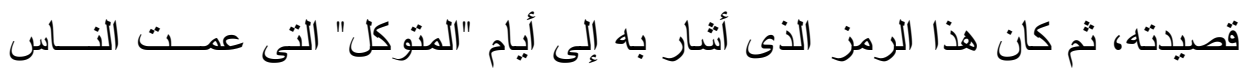

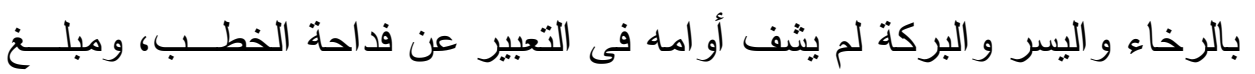


حزنه، فتخلص من الكناية إلى التصريح، وبكى الخليفة أحر بكاء، و أنكر علـى

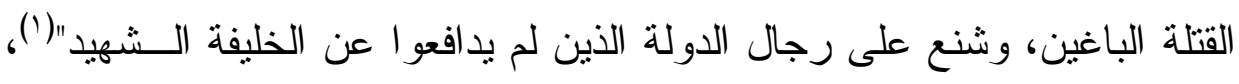
يقول: - n

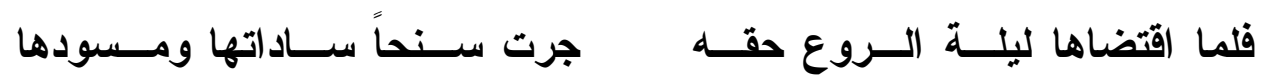

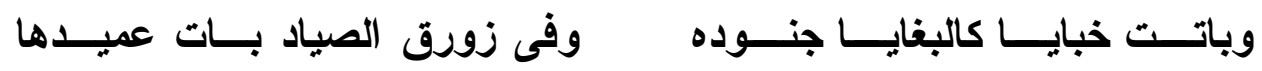

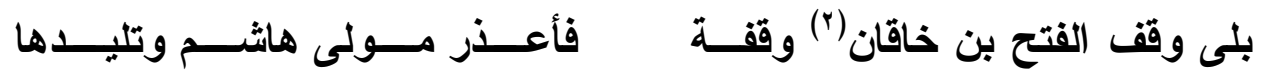
وجــاد بــفس حسرة ســـلت لــهله ورود المنايا حيث يخشى ورودهـــا لقد جاد "الفتح بن خاقان" بنفسه فداء للخليفة "المتوكل" فى حين فر "عبيدالله بن يحيى"(") و اختبأ فى زورق الصياد الذى كان فى النهر، وكان من الأولـى أن يدافع هو عن الخليفة فهو وزيره الذى اختارهوقربه منه ووثق به، يقول:

إلى ســقر الله البطــــ خمودهـــا

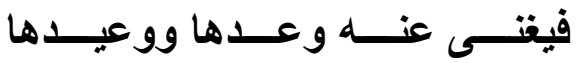

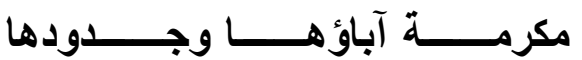

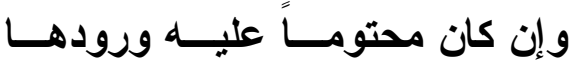

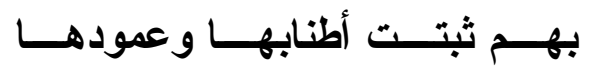

وفــــر عبيــــــالله فـــيمن أطاعـــهـ ولم تحضر السادات من آل مصعب ولــو حسـرته عــبة طاهريـــة لعز على أيــــى المنـــون اختر امـــهـ

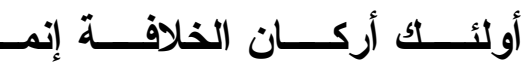

$$
\text { انظر : الديو ان ص(9 (1). }
$$

الفتح بن خاقان بن عرطوج من أبناء الملوك من الأتر الك اتخذه المتوكل أخاله، وكــان

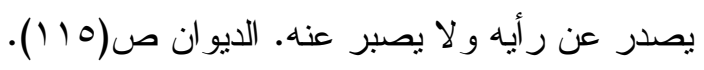

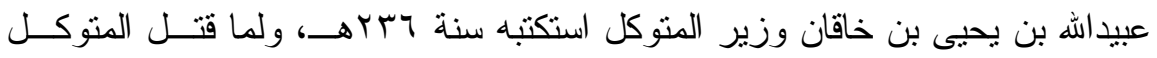

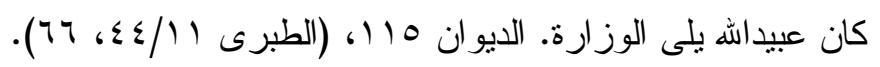


كما أثناد بدور "الفتح بن خاقان" ودفاعه عن الخليفة حتى ذاقا الموت معــاً، و أدار اللوم على "عبيدالله بن يحيى" ونوه بدور آل مصعب وهم بنو "عبدالله بـن

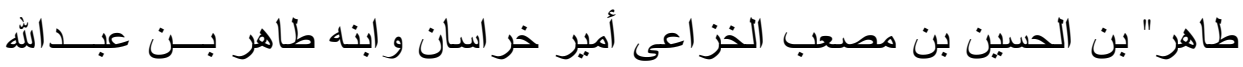

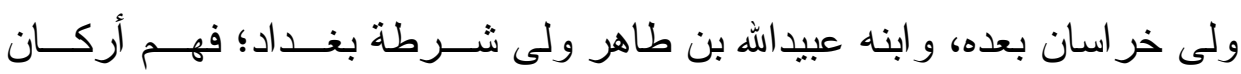

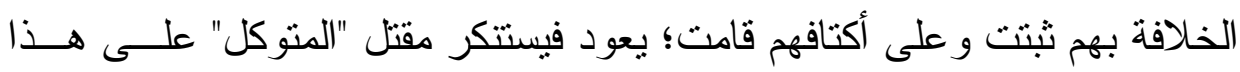

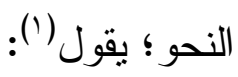

على فرقة صبراً وأنــتم شـــهودها ولا دافع عن نفـسه مــن يريـــــا ملوك بنى العباس مــنهم ســـودها سيبلى على طول الزمـــان جديـــــا

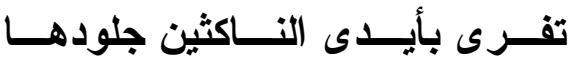
ويحكم فى أرحــامكم مــن يكيـــــا أذلـــت لــضـبعان الفـــلاة أســـودهـا وأعظـــم آفــات الملـــوك عبيــــــــا ـقبور وما ضمت عليــه لحودهـــا

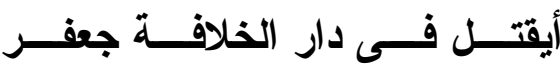
فلا طالب للثـأر مــن بعـــ موتــهـ بنو هاشــم مثــل النجــوم وإنمـــا بنى هاثـــم صــبراً فكـل مــصية عزيز علينـــا أن نــرى ســـرواتكم

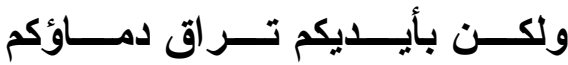

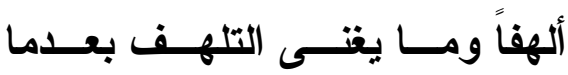

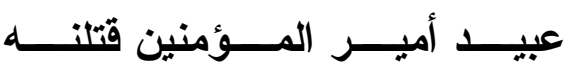

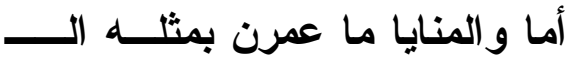

قتل "المتوكل" خليفة المسلمين فلم يجد ناصر اً يدفع عنه القتل ومن حــاول

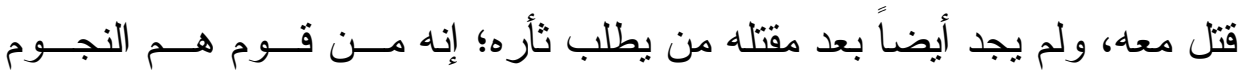
الزاهرة، و لا بد من الصبر على هذه المصيبة التى عمت المسلمين فعزيز عليهح

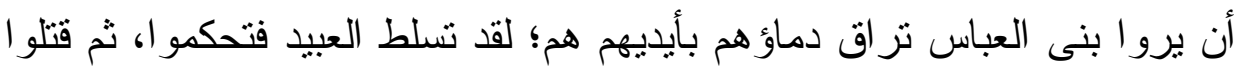

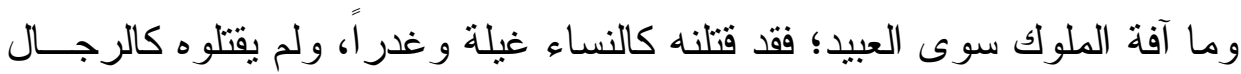


وجهاً لوجه فماذا يغنى التلهف و الحسرة بعدما أذلت الأسود وســقطو ا صــرعى الفلاة التى سودت الضبعان. ثم ينادى "المتوكل" مؤبنا إياه؛ فيقول:

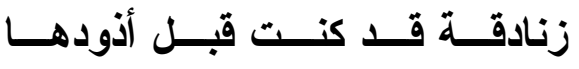

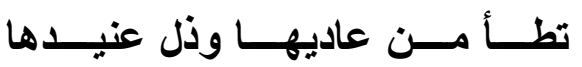

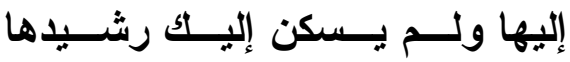
يشيد بها فــى كـلـ أرض مسشيدها صدور الموالى واستسرت حقودهـــا وكاتت أمور لــيس مثلــى يعيـــــا
فيا نـاصر الإســلام غـرك عـصبة وكنت إذا أثـــهنها بــى مــشهـاً

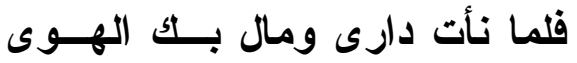
أثشاع وزير السوء عنـــ عجائبـاً وباعد أهل النصح عنك وأوغـرت فطل دم ما طل فــى الأرض مثلـــه لقد ظل الرجل على وفائه للخليفة محباً له ومؤيداً رغم ما حدث لـــه منــه، و هاهو يغضب لمقتله ويحزن على فقده، وهو المبعد الطريد البعيد عنه، ولو أراد

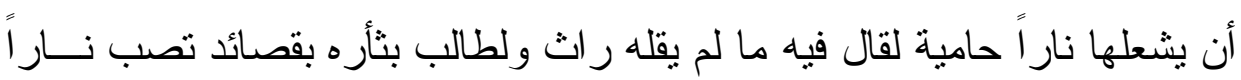
ولهيباً على رعوس القتلة ومغتصبى الخلافة، ولكنه صرف همه إلى فقيده ناصر

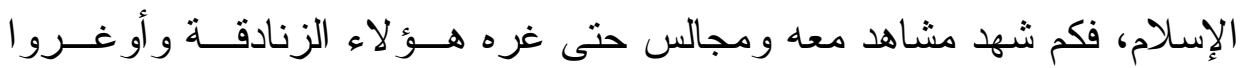
صدره عليه فأبعده عنه، و انفرد به وزير سوء أخذ يباعد بينه وبين أهل النــصح و الرشاد حتى انصرفو ا عنه فسكن الحقد قلوب المو الى فما كان من مخرج سوى القتل وسفك الدماء، وكل هذه أمور صار من الصعب إصلاحها. نقلت هذه الحادثة وتللك الفاجعة و المصيبة الكبرى نفس الثـاعر إلى طـــور

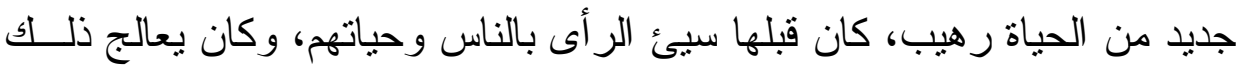
بالسخرية منهما، ولكن بعد مقتل "المتوكل" بتدبير "المنتصر " ئس من الحياة ومن

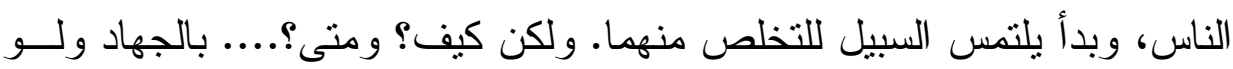




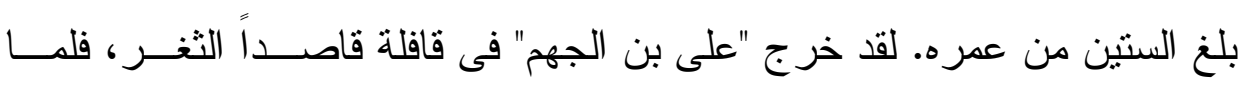
كانو ا فى "خساف" خرج عليهم نفر من الأعر اب الكلبيين، فهرب من كــان فـى لـى

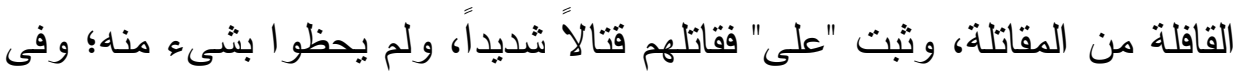
ذلك يقول:

صبرت ومثلى صبره لــيس ينكـر وليس علـى تـرك الـتقحم يعـذر فلما كان من الغداة خرج على القافلة منهم خلق كثيــر ، فتسـر عت إلـــهـم

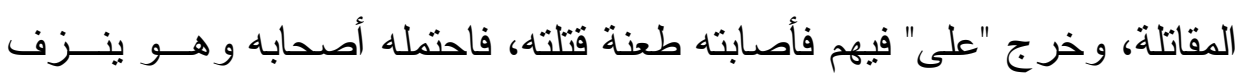
دمه، فلما أحس بالموت جعل يقول:

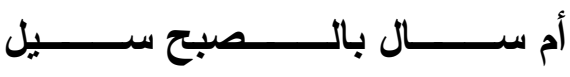

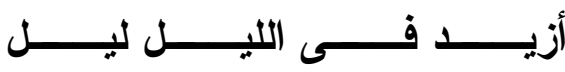

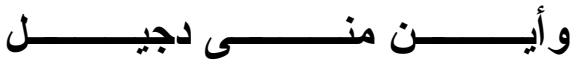

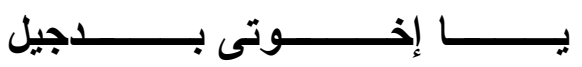
فأبكى كل من كان فى القافلة، ومات مع السحر، ووجد معه رقعــة حـين نز عت ثنابه بعد موته فيها قوله:

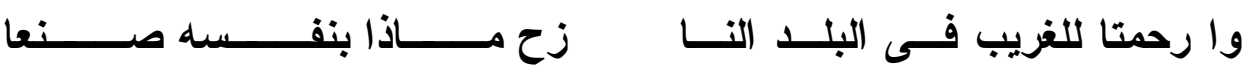

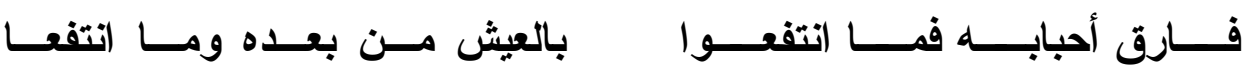
ودفن فى ذلك المنزل على مرحلة من حلب"('). وقد رثاه جماعة من الشعر اء منهم أبوصاعد(r) فقال: أريقى الـــمع واجتبــى الهجوعـا وصونى شـــل وجــلك أن يــضيعا انظر : الديو ان ص (r/ ())، كان منزل على بن الجهم فى شار ع دجيل ببغداد.

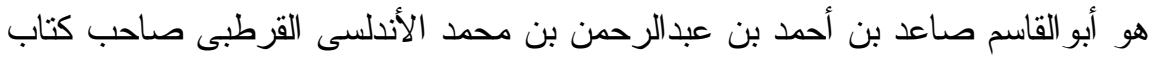

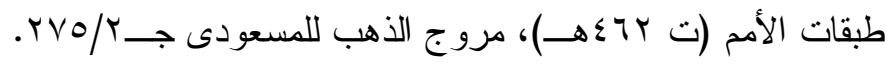


غـــــا بالـــشام منجــــلاً صــــريعا

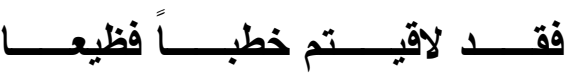

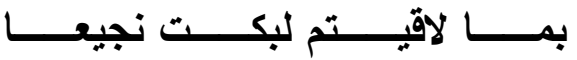

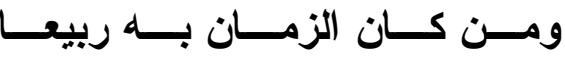

(1)

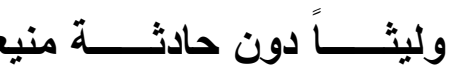

وقهــولى إن كهـــف بنـــى لـــؤى

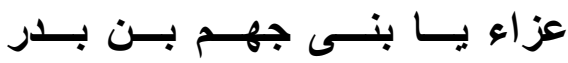

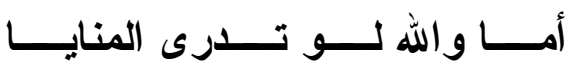

ثــوى كهــف الأر امـلـل و اليتــامى

فتى كان الــسهام علـــى الأعــادى

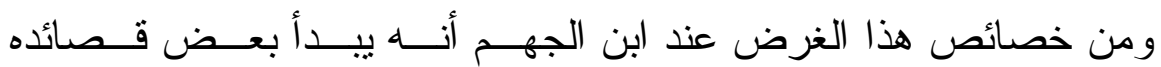

بالاستفهام التعجبى كى يثير النفس ويوقظ الذهن ليرى فداحة الخطب الذى نـزل و المصيبة التى ألمت بالناس لفقد حبيب لديهم.

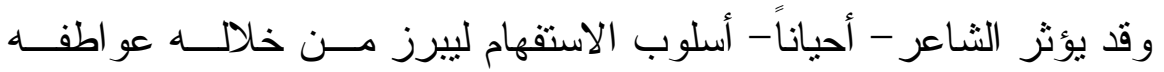

ومشاعره؛ كأن يقصد به الرجاء، أو التحسر، أو الإنكار؛ أو التعجب، أو الحيرة،

أو التردد، أو غير ذلك من المعانى المجازية؛ منل قول الثاعر:

سؤال الدهر: أيسن المـسلمونـا؟(؟)

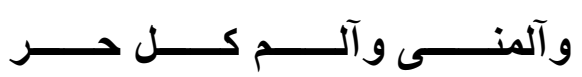

ومثال ذلك قول "على بن الجهم" فى "'عبداله بن طاهر "' أشنهر الو لاة فـى

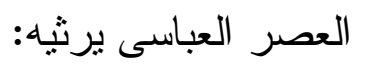

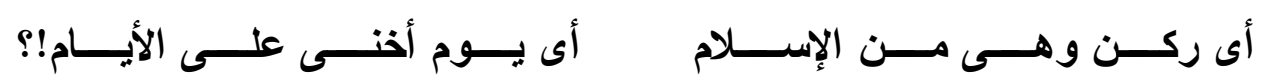
لقد وهى ركن ركين من أركان الإسلام بموته، وحلت مصيبة كبرى علـىى الأيام التى يحياها الناس.

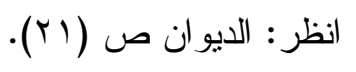

انظر : دراسات فى النص الأدبى (العصر الحديث) ص (•^)، د/محمد عارف محمود

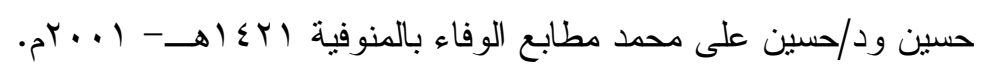


و مثله يرثى نفسه بعد أن طعن بسهم الأعداء؛ قال وهو يموت:

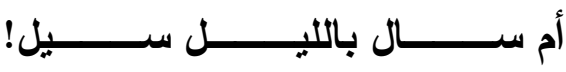

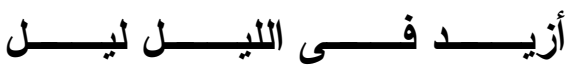

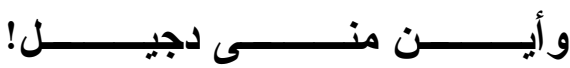

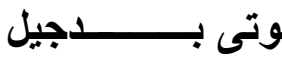

إخ

وقد يورد الاستفهام الإنكارى طى قصيدة الرثاء لإثارة الذهن، وللتعبير عن

استتكار ها حدث ومثاله قوله يرثى المتوكل:

على فرقة صبراً وأنــتم شـــهودها؟

أيقتـــلـل فــى دار الخلافـــة جعفـــر

وقوله:

ألهفاً ومـــا يغتـى التلهــف بعــما أذلت لــبعان الفــلاة أســودها؟ وقوله يرثى "'"عبدالله بن طاهر "'" فى القصيدة المشار إليها سلفاً:

ـالــ لاى فادح الخطوب العظـــام؟

من باداوى الدنيا ومن يكلأ المد

كما يلاحظ أنه يضم إلى الرثاء بالصفات العامة صفات خاصـــة بــالمرثى

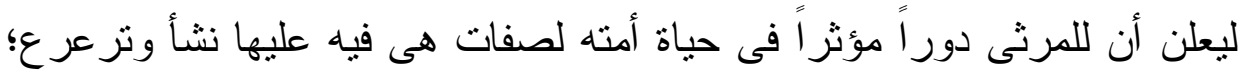
فيقول فى "عبداله بن طاهر":

وأباحـــت حمـــى عزيــز المــــر ام

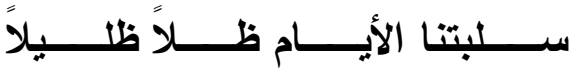
س محــل الأرواح فـــى الأجــسام يا بنى مسـصب حلــتم مسـن النــا عــم مـــا خــــم جميـــع الأكــام

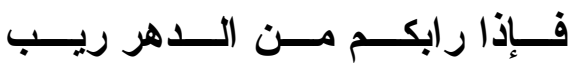

ويقول فى "القتح بن خاقان" الذى حضر مقتل "المتوكل" وحاول منـع القتلـــة وصدهم عن المتوكل؛ بل دافع عنه حتى قتل معه:

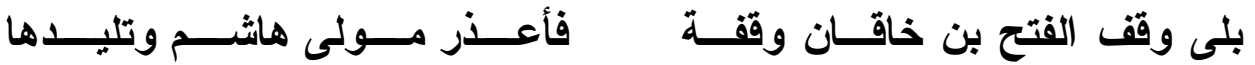




\section{ملامع النجابة والفهم فى شعر على بن الجهم}

وجـاد بــفس حسرة ســـلت لــهله ورود المنايا حيث يخشى ورودهــا ويشيع فى رثائه الحديث عن الصبر و التصبر و الموت، منل قوله:

سيبلى على طول الزمـــان جديــــا بنى هاثـــم صــبراً فكـل مــصيبة

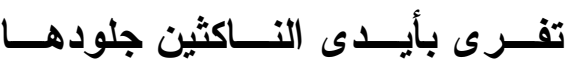
عزيز علينــا أن نــرى ســـرواتكم ويقول فى "عبداله بن طاهر":

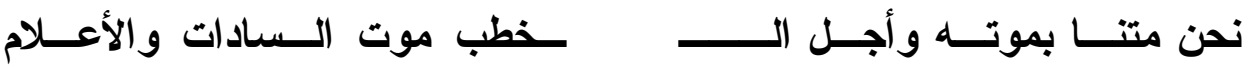


ملحوظات فنية عامة:

1- يلحظ الدارس لشعر "على بن الجهم" أن مطالع قصائده فى معظمها خــال من التصريع؛ ومنها على سبيل المثال قصيدة: "هذا العقيق"؛ وفيها يقول:

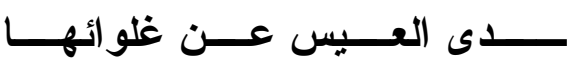

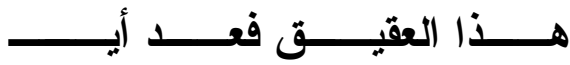

وهو أول بيت فيها، و البيت المصر ع هو الذى غيـرت عروضــهـ رويــاً ووزناً لتلحق بوزن الضرب، من أجل المجانسة بين شطرى البيت الو احــد فــى هـ

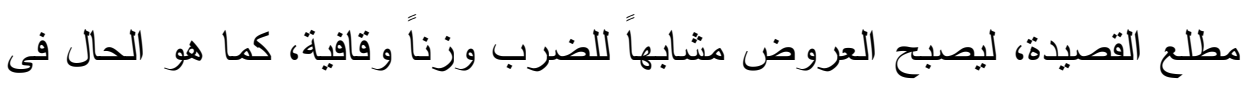
المققى، غير أن الموافقة تتم بتغيير فى العروض إما بزيادة، كقول الثناعر مــن الطويل:

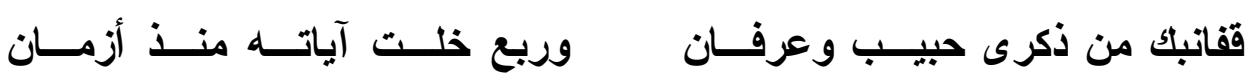
حق عروضه أن تجئ على وزن "مفاعلن"، لكنها غيـرت بالزيــادة إلــى

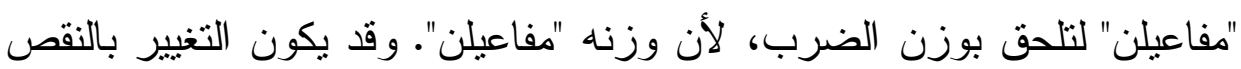
كقول امرئ القيس من الطويل:

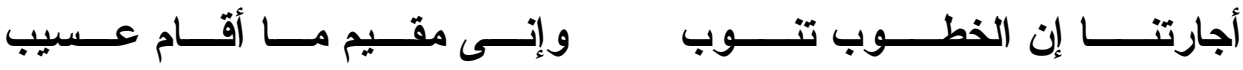
وزن عروضـه "فعولن"، حقها أن تجئ على وزن "مفاعلن" لكنهـــا غيــرت
بالنقص لتلحق بوزن الضرب "فعولن"( ).

ومن قصائد "على بن الجهم" التى خلت من هذا التصريع قــيدة: "قالــت

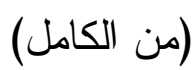
حبست"؛ يقول فى أول بيت فيها:

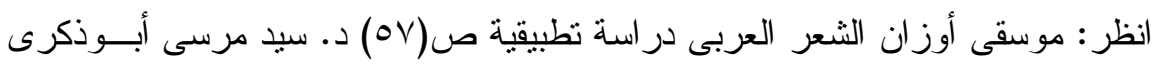

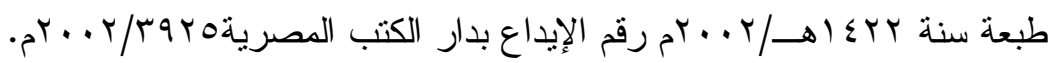




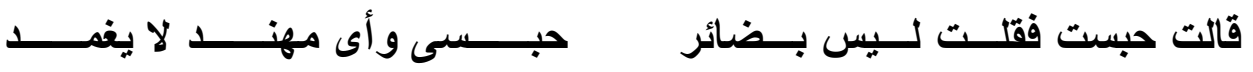
ومنها قصيدة: "لم ينصبو ا بالثاذياخ"، ويقول فى أول بيت فيها:

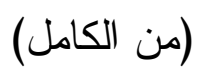

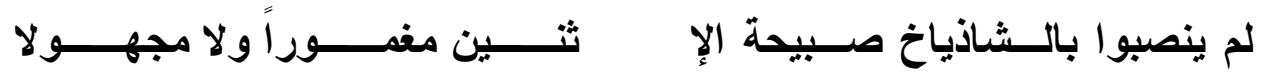

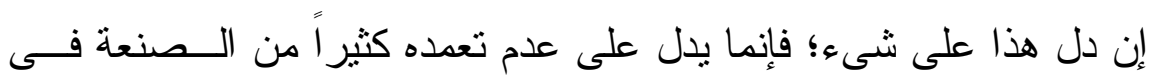

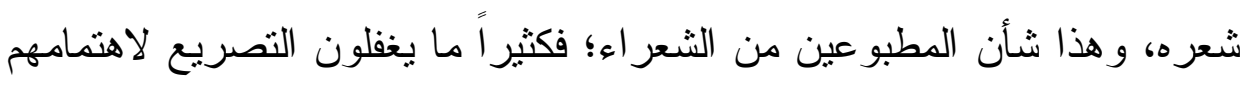

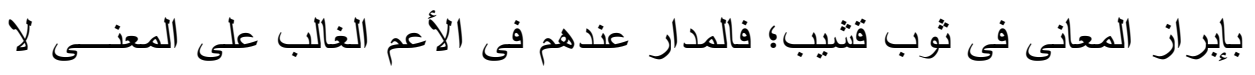
على الصنعة. r- كما يلحظ أنه أقل شعر اء عصره صنعة، لا تكاد تجد فى شعره شيئًا مــن المحسنات اللفظية، و إذا وجدت فعن غير قصد منه؛ ومن ذلك قولــهـ فـى

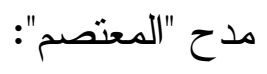

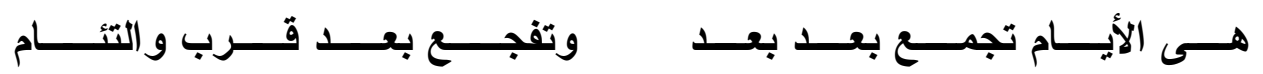
فهذه مقابلة جميلة بين حالتى الأيام؛ فمرة تجمع الأحبــاب بعـــ تفـرقهم وبعدهم، و أخرى تفجعهم بالبعد و التفرق، ولم يحمل البيت محسناً لفظيــاً واحــــاً. سوى قوله: بعد بعد؛ حيث جانس بين الظرف و المصدر .

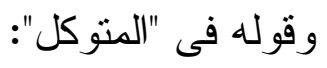

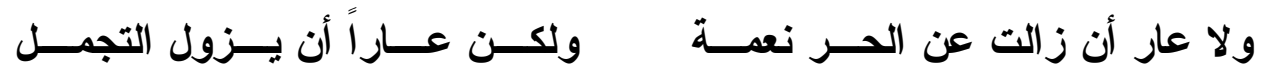

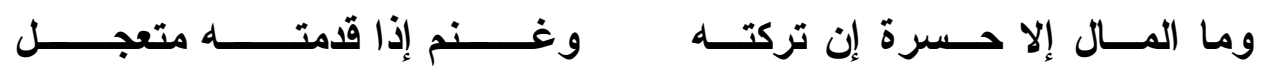

فليس العار فى زو ال النعمة عن الحر، إنما العار فى زو ال التجمل مقابــــة جميلة وكذلك المال يكون حسرة إن تزك دون إنفاق، ويكون مغنماً إذا أنفق فـى - Iro 


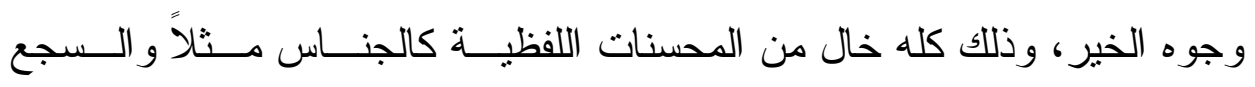
و غير ها. و ونه قوله فى "المتوكل" يمدحه:

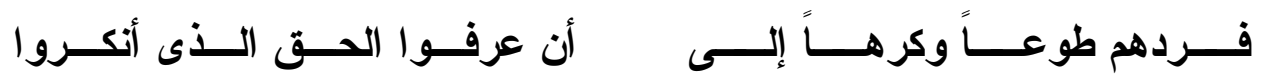

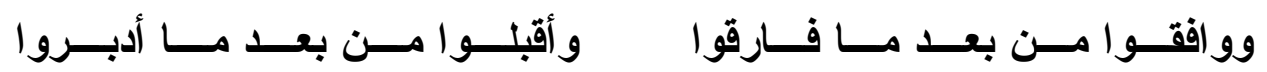

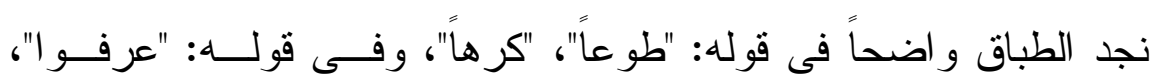

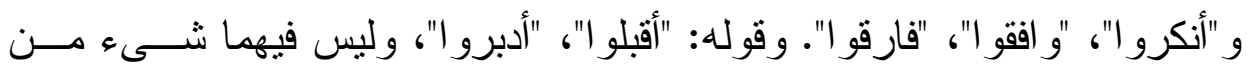
المحسنات اللفظية.

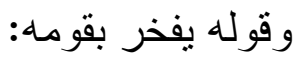

أولئــك آل الله فهــر بــن مالــك بهم يجبر العظم الكـسير ويكسر

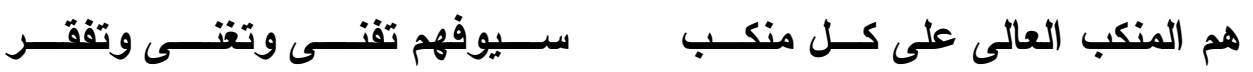
فقيه نجد الطباق فى قوله: "يجبر"، "يكسر" وفيه نجد جناساً بــين الكـسير ويكسر، وبين "تفنى وتغنى "، وفى قوله: "تغنىى"، "تفقر"، طباق. "ولم يتعدده؛ بــلـ

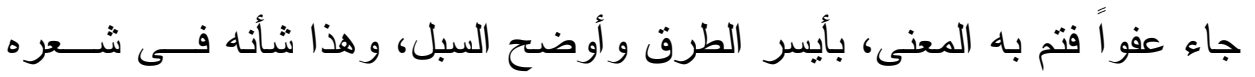
كله؛ بله المدح و الهجاء و الفخر و الرثاء. بـاء. بلهن وقوله فى "المتوكل" يمدحه:

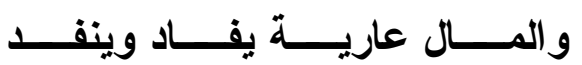

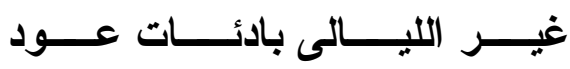
أجلى لـــ المكــروه عمـــا يحمـــ

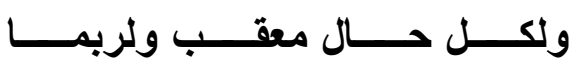
فالطباق و اضـح بين قوله: "بادئات"، "عود"، وفى قوله: "يفــاد"، أى يجمــع و "ينفد"، أى يضيع ويصرف وينتهى. وفى قوله: "المكروه"، "يحمد". 
وفى قوله:

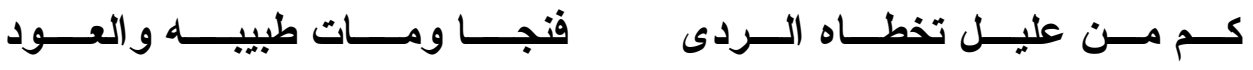
طابق بين قوله: "تجا"، "مات"، ومعلوم أن هــذا اللـــون مــن المحـسنـات

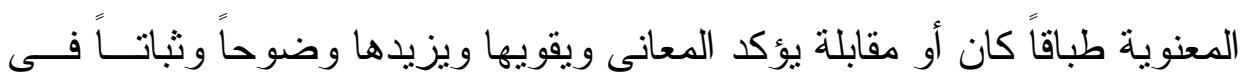
ذهن المتلقى؛ فالضد يظهره حسن الضد عند وروده على الذهن فهـــ "يعكـس

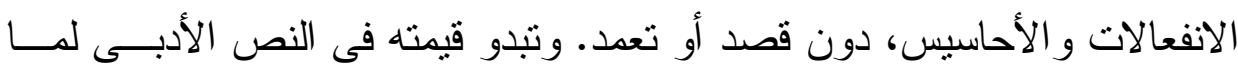
يثير من مشاعر المو اقف المضادة، ويظهره من عو اطف خلال الرو ابط البعيدة، مما يؤدى إلى إيقاع صوتى له رنين موسيقى يثير القارئ، ويوقظ نفسه، ويعدـق شعوره بالمعنى، من خلال المجاورة بين الضدين" (').

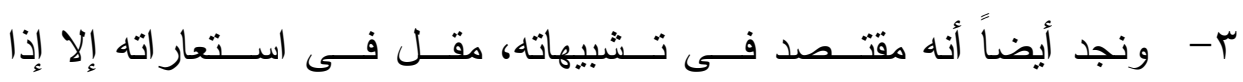
اقتضى المعنى ذلــلك فيوضـــح بالتــثبيه، ويــزين بالاســتعارة؛ ليــصل بالمعنى درجة عالية من الصفاء و النقاء؛ ومن ذلك قوله:

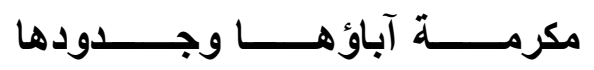

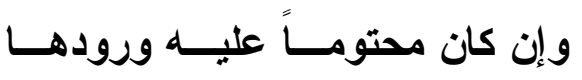

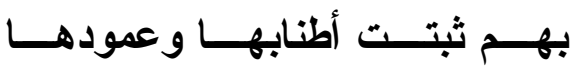

ولـــو حـضرته عــصبة طاهريـــة

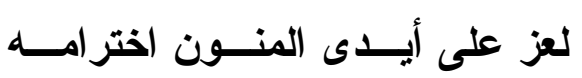

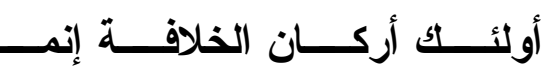

استعارة مكنية جميلة فى قوله: "لعز على أيدى المنون"؛ ومن يفر من أيدى

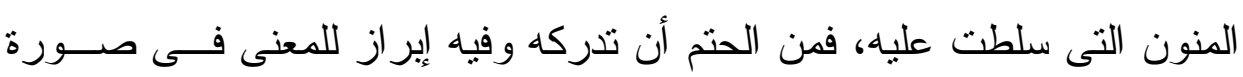
محسوسة تز اه العين أو تكاد. وهذا منل قول "أبى ذؤيب الهذلى": 


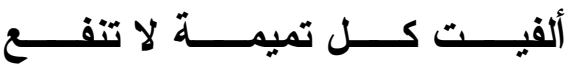

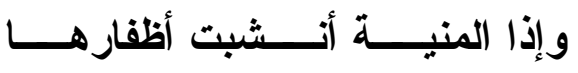

فالثـاعر قد صور المنية حيو اناً مفترساً، ولما كانت المنية تقـضى علـى

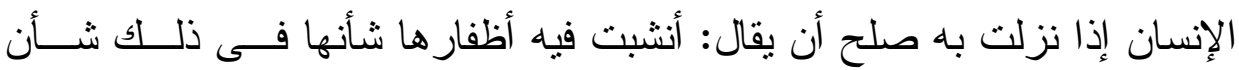
الحيو ان المفترس. وجعل "على بن الجهم" للمنون أيدى تخترم الإنسان حين يأتى إلى أجله المحتوم حتى لو لم يكن لها أظفار تتشبها فيه فأتى إلى المعنى مـن أيسـر

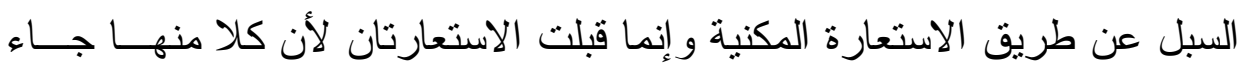
على ما يتطلبه عمود الثعر العربى من ملاعمة المستعار للمـستعار لـــه ومــن تقاربهما ومن تحقق الصفات الأربعة التى ذكر ها "أبوهلال العسكرى" ('). وفى قوله: "بهم ثبتت أطنابها و عمودها"، استعارة تصريحية حيــث شــبه

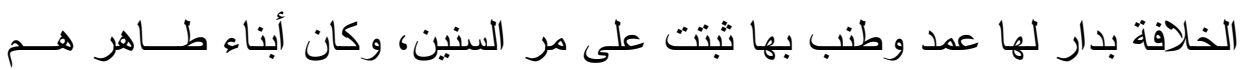
عمدها و أركانها؛ وفى ذلك ترشيح ر ائع للاستعارة وضـح به منزلة هؤ لاء القــوم من الخلافة وقربهم من الخليفة. ويقول أيضاً:

بنو هاثــم مثـل النجـوم وإنمــا ملوك بنى العباس منهــــــــودها فقد شبه بنى هانتم بالنجوم الزهر التى تتير للناس سبيلهم فى الليل المظلــم

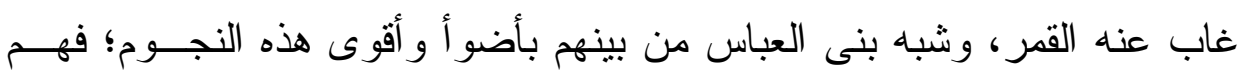

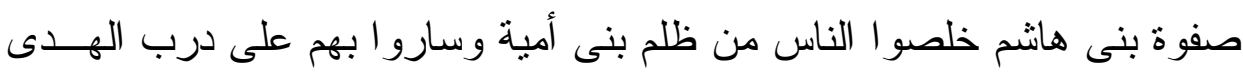

$$
\text { و العدل و الإيمان. }
$$

انظر : عمود الثعر العربى ص (ع • ب) د/عبدالفتاح على عفيفى مطبعة السعادة طبعـة

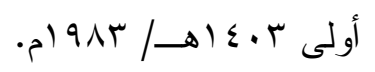




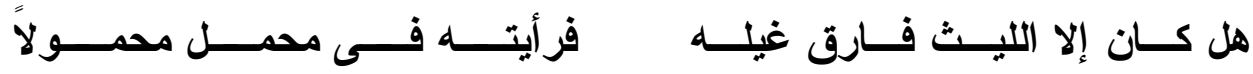
حيث شبه نفسه و هو مصلوب بالليث ثم حذف المـشبه وذكــر مرشـــات

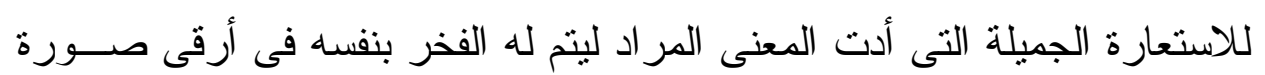
كما أر اد منه. ومنه قوله أيضاً:

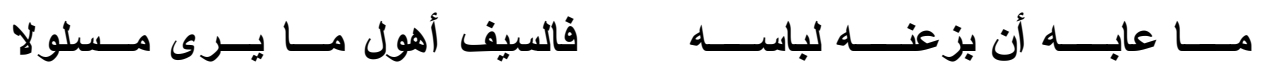

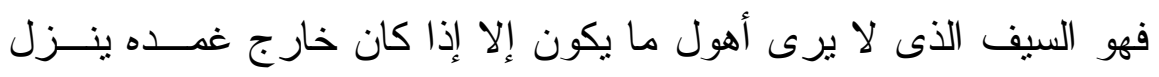

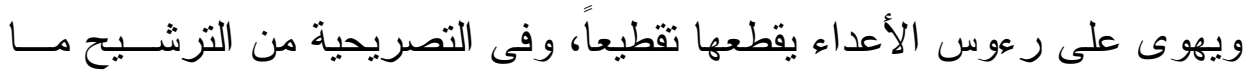

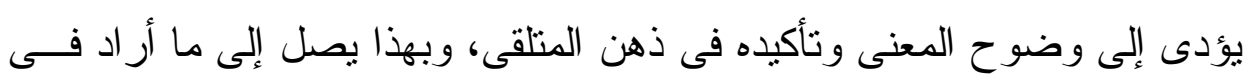
مقام الفخر بنفسه. ويقول أيضاً:

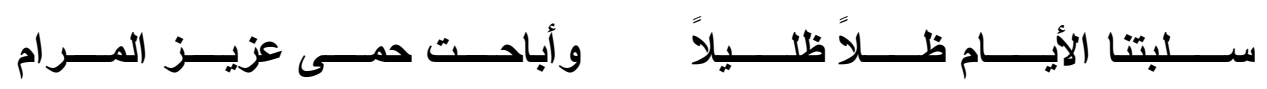

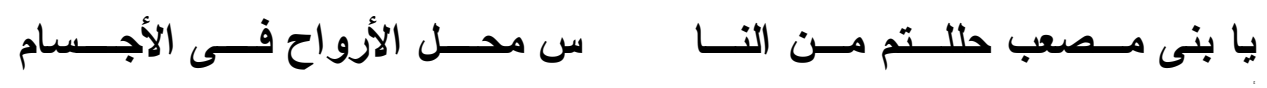

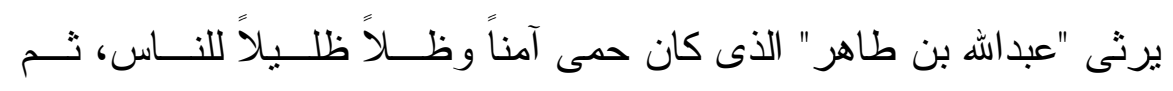

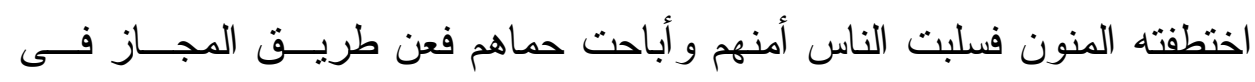

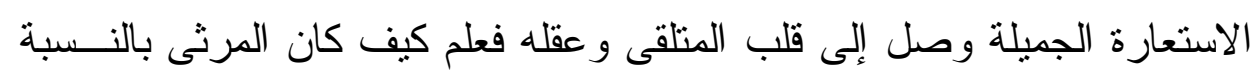

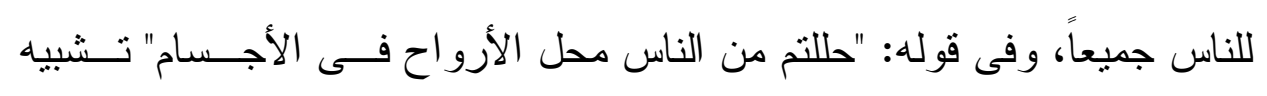
جميل وضح به منزلة هؤ لاء المدورحين فى قلوب الناس.

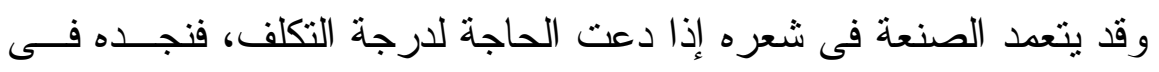

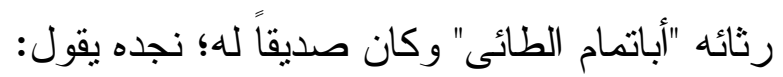

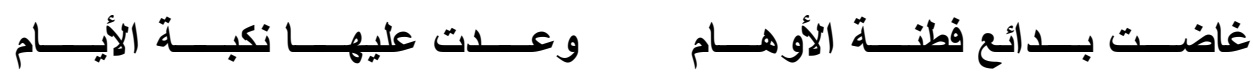


وغدا القريض ضئيل شخص باكيـاً: بـــشكو رزيتــــه إلــــى الأقـــلام

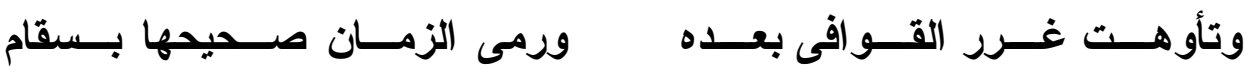

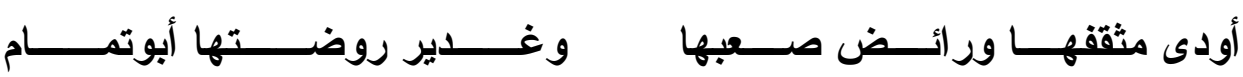

استخدم طريق المجاز فى رثائه فأكثر من الاستعار ات الغريبة من مثــل:

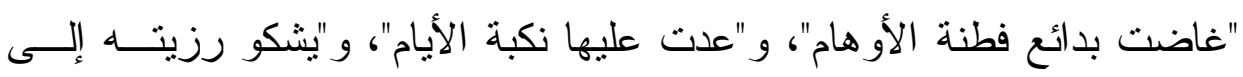

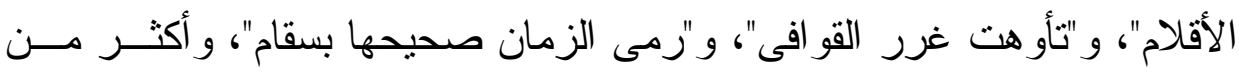

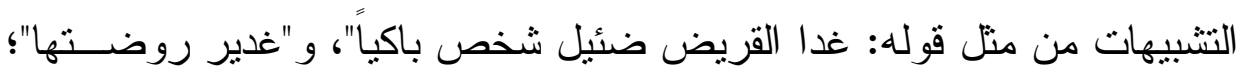

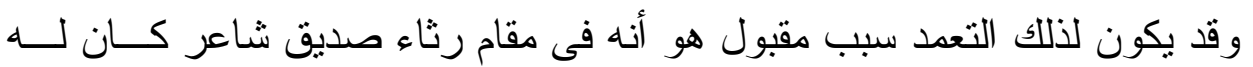

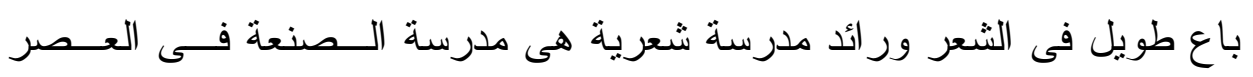

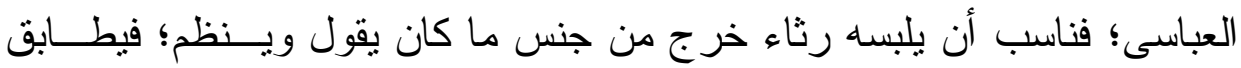
قوله مقتضى الحال رثثاء، ومقتضى المقام فناً. ع - نجده أيضاً يستعمل أسلوب الحوار ليثير ذهن المتلقى فيستقر المعنى فيــه،

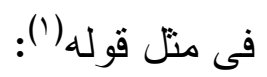

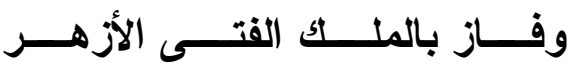

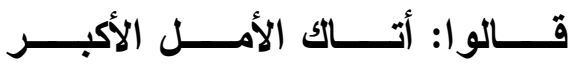

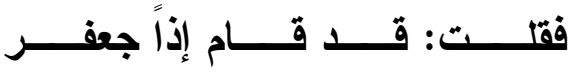

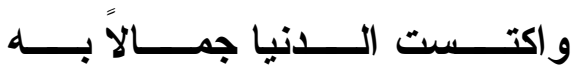
فالحو ار فى قالو ا، وقلت، يثير فى الأسلوب حركة، وفى الذهن انتباهاً لمــا

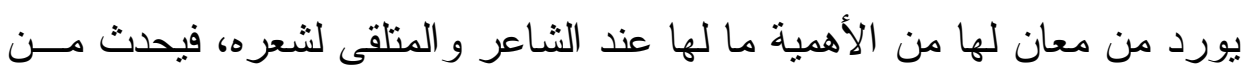
التلاقى و التو افق بينهما الكثير؛ وبهذا يستقر المعنى وتطمئن النفس إليه. ويقول أيضاًً) 
الـــــشمس أم ســـــــــــا جعفــــــر

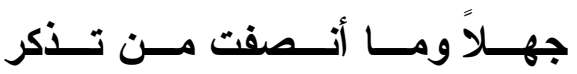

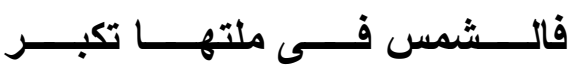

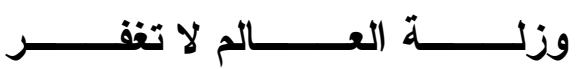

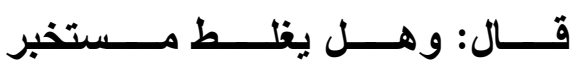

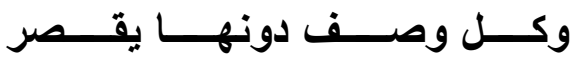

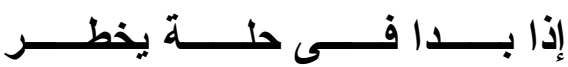

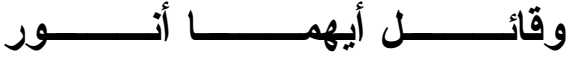

قلت: لقد أكبرت شــمس الــضى

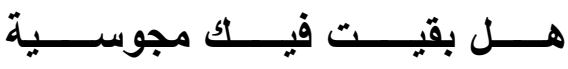

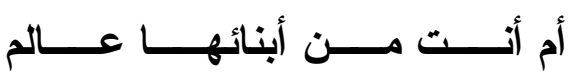

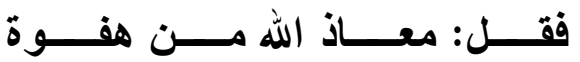

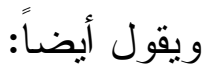

فــى كـلـل وقــت نورهـــــــــــــ

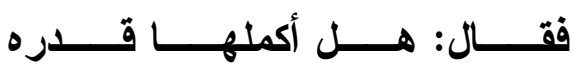
ويقول أيضناً:

قلــــــــت و لا أضـــــــعافه أبحـــــــر قــال: وأيــن البحــر مــن جــوده والجـــود فـــى كفيـــهـه لا يحــــر

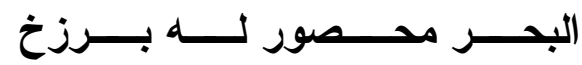

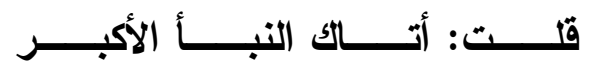

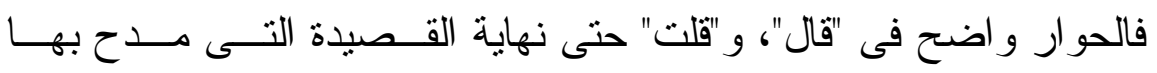
"المتوكل"، وكانت من أول ما قال فيه من الثتعر لما فيهــا مــن شــر وح ســيرة "المتوكل" لما استخلف.

ويشيع الحوار أيضاً فى قوله يمدح "المتوكل" أيضاً فى أثهر قـصائده('): (خليلى ما أحلى الهوى و أمره).

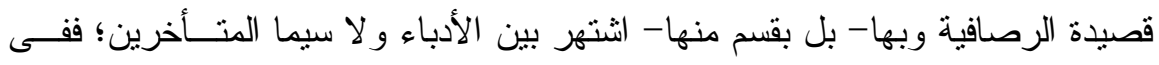

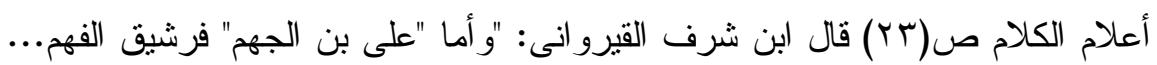

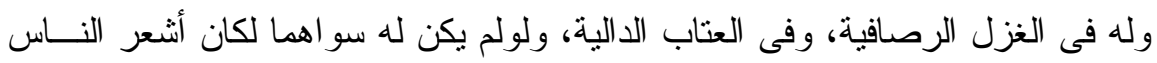

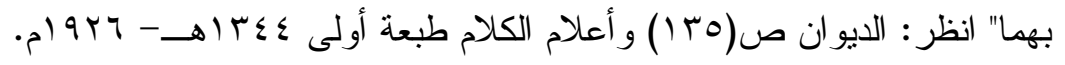


وفيها يقول:

لجارتها: ما أولــع الحـب بــالحر معنى وهل فى قتله للك مسن عـذن أنس

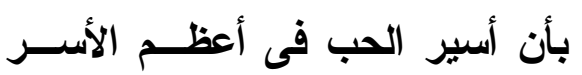

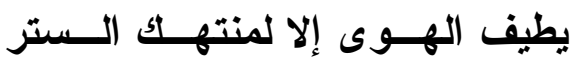
من الطارق المصغى إلينا وما ندرى

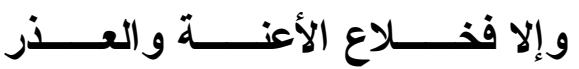

وما أنس م الأثبياء لا أنس قولهــا فقالت لها الأخــــى فمـــا لــصديقنا صليه لعل الوصل يحييــه و اعلمــى

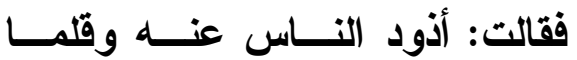

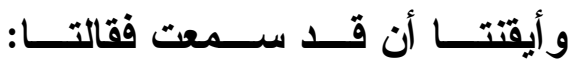
فقلت: فتى إن شئتمـا كــتم الهــوى

صاغها على الحوار فجاءت الحركة و اضــــة للعـين بـين الثخــصيات المتحاورة مما يعطى القصيدة لوناً من الحياة و الحركة و الروعة و الرونق تـرى على أرض الو اقع. فحواره يبدأ مع خليليه وهذا لون من التجريد، ومن دلالات تجريد الثاعر من نفسه شخصناً آخر يخاطبه وقوع صر اع بين النفس و العقل، أى بين الرغبـــة فى شىء لداعية الهوى و الرغبة عنه لداعية أخرى صارفة('). ثم يتحول من ذلك إلى حوار حبييته مع صديقتها من خلال حديثه عنهما ورو ايته لما حدث بينهــــا من حديث العشق و الهوى، ويتحول إلى دخوله معهما فى الحـــوار فــى "قلــــ"، و "قالت"، و "صليه" و"أيقنتا"، و "هجينا"، "فما لصديقنا"، "فقالتا" حركة دائمة مستمرة و إبر از للشخصيات ودور ها فى النص كأنه نص مسرحى يمنل وير اه النظــارة.

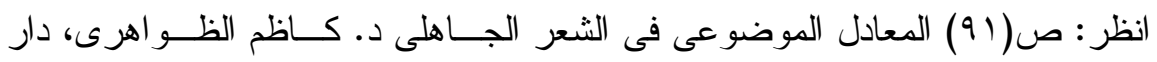

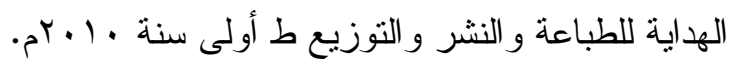


"و الحوار هو الوسيلة الجمالية الناجمة لإبراز العو اطف المضطربة و المتناقـضة

بين الحبييين" (') - (1)

ه- كما يقل فى شعره التقديم و التأخير، و الحذف و التقدير ، وما يقتضى إدامـــة النظر ، و إعمال الفكر؛ بل كان يتطلع إلى تأدية المعنى على أوضتح الـسبل وهيل و أيسر ها، فقد كان بصير اً بحدود الكلام، ومن أظهر خصائص شعره الطبح الطبع

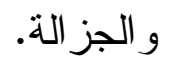

7- ومن بطالع قصائده قبل الحبس وبعده يجده فى شعر الثباب أثـــبه بـشـر

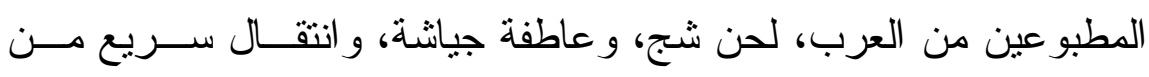

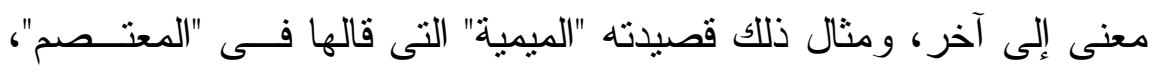
و وأولها:

سقيث معاهـــا صــوب الغــــام(؟) متى عطا ـــت ربــاك مــن الخيــام

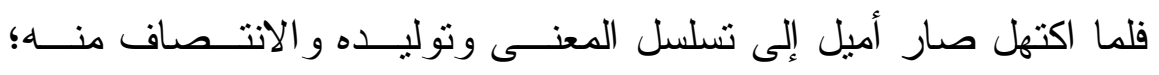
فقصيدته "الدالية" فى الحبس وحدة تامة منسلسلة، وكذلك أكثر قصائده التى قالهـــا. فى "المتوكل" أو فى زمانه.

و الجزل المحكم من شعره أثنبه بشعر فحول الجــاهليين و المخــضـرمين؛ كز هير بن أبى سلمى و النابغة الذبيانى و الحطيئة، مثنال ذلك قوله: ويجزى على الحسنى ويعطى فيجزل

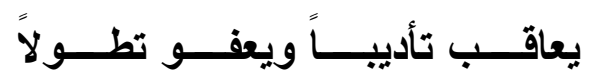

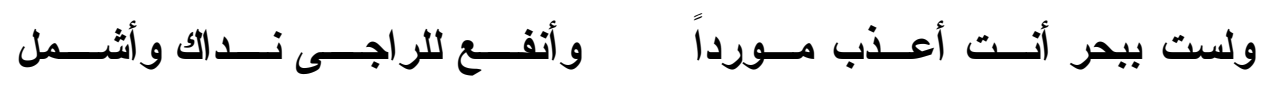

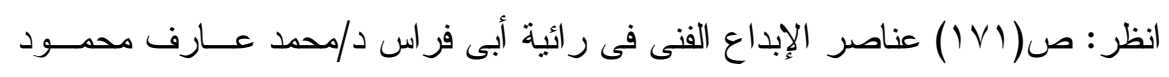

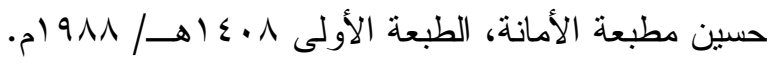

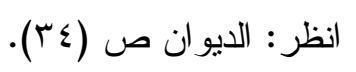




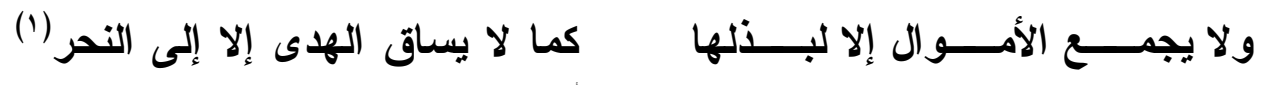
-V وما قاله من الشعر أيام محنته من أجود الثعر ، وأحسنه ومنـــه قــصيدته الدالية؛ فهى من القصائد الخالدة، لم يقل فى معناها مثلها، أبدع فى ابتكــــار معانيها وتسلسلها كما أبدع فى صو غها. و أولها قوله:

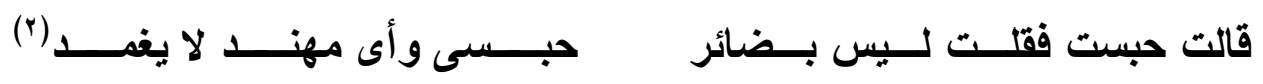
1- - نجده يتتاول المعنى البعيد فيعرضه قريباً من الفهم، ويتـصرف بــالمعنى

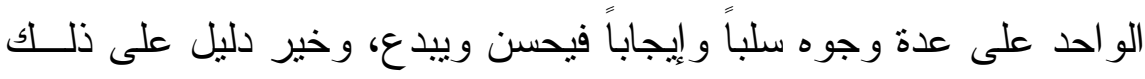

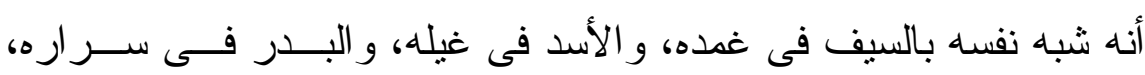
و الشمس فى حجابها، و الغيث فى غمامه، و النار فى أحجار ها، و الرماح فى كعوبها، وذللك فى قصيدته المشار إليها آنفاً؛ وفيها يقول:

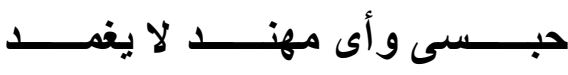

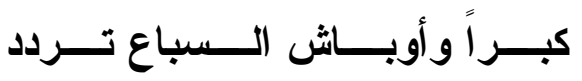

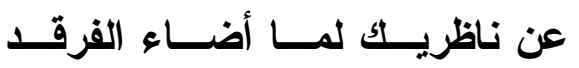

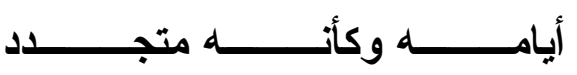

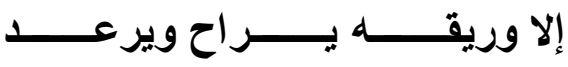

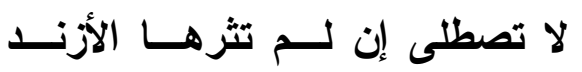

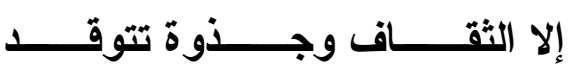

قالت حبست فقلـــت لــيس بــضائر أو ما رأيـــث الليــث يــألف غيلـــه و الــشمس لـــولا أنهــــا محجوبــــة و البـــر يارككــه الــسر ار فتنجلــى والغيث يحصره الغمام فمـــا يـرى

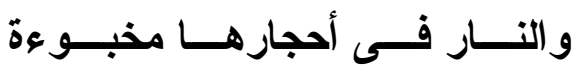

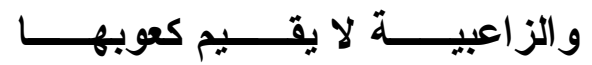

$$
\begin{aligned}
& \text { انظر : السابق ص (ror). } \\
& \text { انظر : الديوان ص (^^). }
\end{aligned}
$$


فمهما ظل السيف مشر عاً فى وجوه الأعداء يصيبهم فى مقتـل ســتنجلى المعركة عن نصر مبين بعده يعود السيف إلى غمده، و الأسد من عادته أنه يألف

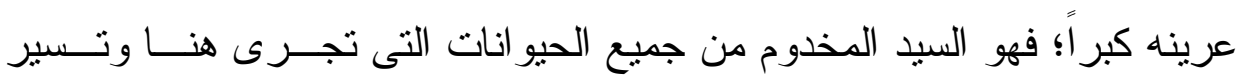
هناك، وهذه الثمس محجوبة عن الأنظار غير مسلطة عليها لو لا ذلك لما أضاء الكون ولما رأى الناس الأشياء، وهذا البدر لولم يمر عليه السرار أى أيام اختفائه

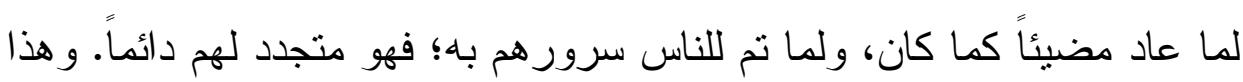

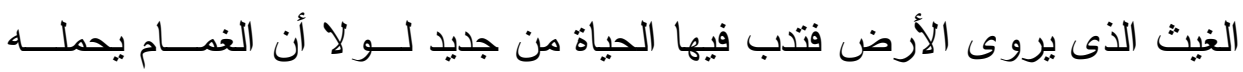

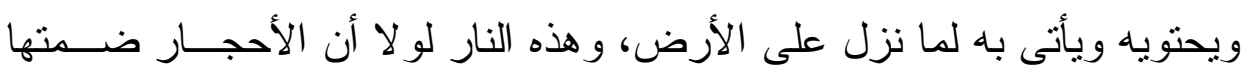

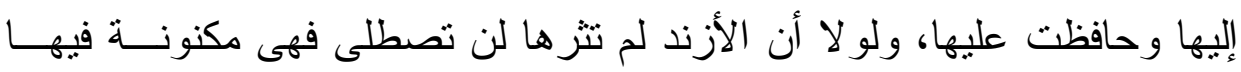
حتى تثار فنقوم بها مصالح الناس، وهذه السهام التى تصيب جسوم الأعداء لولم

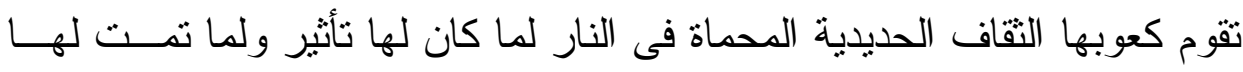
فائدة؛ فقد شبه نفسه وهو فى حبسه بكل هذه الأشياء ليعرف النــاس مــن هـــو،

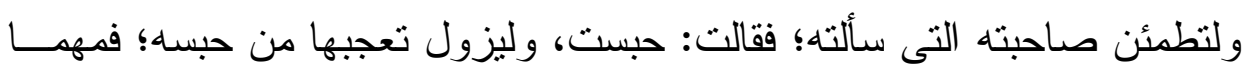

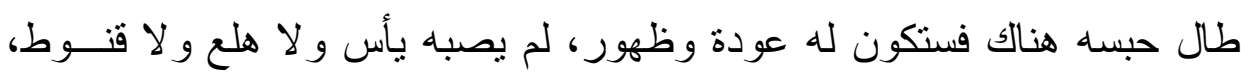
ولم يتغير لايه إحساس ولم يتبدل رأيه فى خلافة بنى العباس، ولم يغضب مــن

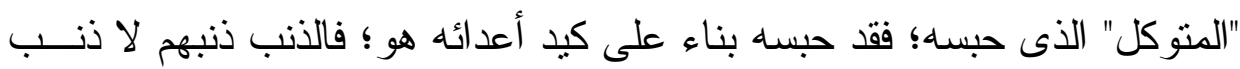

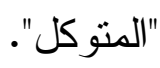

وون ذلك أيضاً تشبيه نفسه عنــدما صــلب بالـشـاذياخ وهــو عريــان،

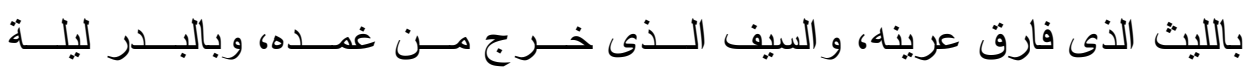
تمامه انقتع عنه الغمام وذلك فى قصيدته اللامية؛ وفيها يقول ('): 


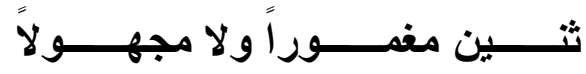

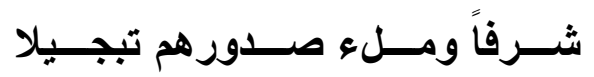

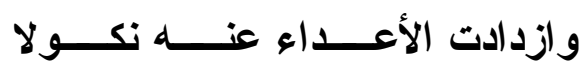

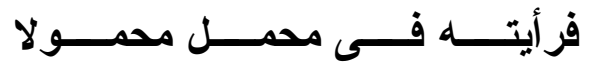

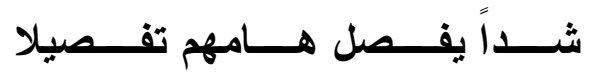

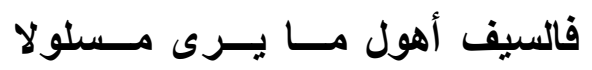

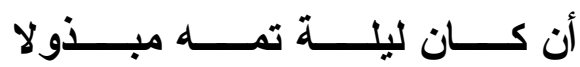

لم ينصبوا بالــشاذياخ صــبيحة الإ نصبوا بحمـــ الله مـلـ عيــونهم

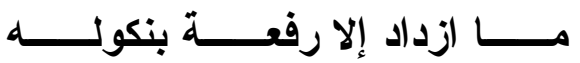
هل كــان إلا الليــث فــارق غيلـــه

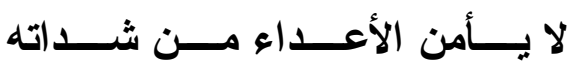

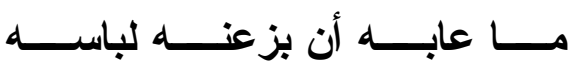

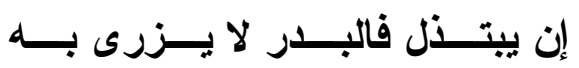

اتضحت لنا الآن صورة المصلوب بعد هذا التوضيح و التقــصيل الرائـعـ؛

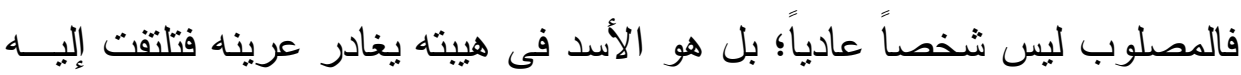
حيو انات الغابة ويلتفون حوله يحتفون به ويقدرونه حتى إذا التقى بأعدائه فهم فى هي هئ لئه

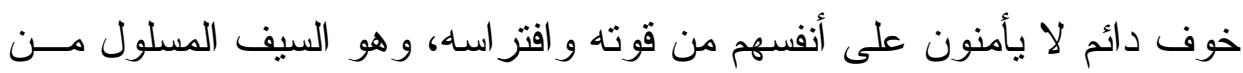

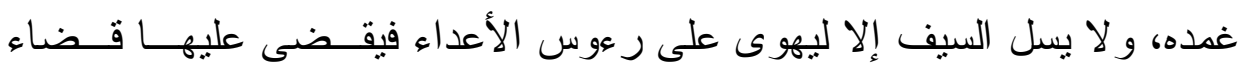
مبرماً، وهو البدر ليلة تمامه يظهر للناس يضـئ لهم ليلهم المظلم فهم فى ســرور دائم معهـ.

$$
\text { ومن ذلك- أيضاً - قوله فى المنوكل: }
$$

عليه بهـــاء حـين يبـدو ويقبـل بخسناك حقاً أنـــت أبهـــى وأجمـلـل فإنــــك أحمــى للــــمار وأبــسل

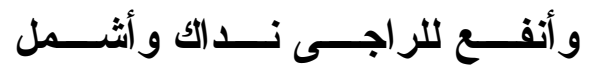
ولا سيب إلا سـيب كةــك أفـضل
ومعتصمى الخلق للــسيف والقتـــا إذا نحن شــبهناك بالبـــر طالعــاً ونظلم إن قسناك باللاثيث فى الــوغى ولست ببحر أنــت أعـــب مــورداً ولا وصف إلا قــــ تجـــاوزت حـــه 
"فالمتوكل" أثنبه ما يكون بأبيه "المعتصم" فى صفاته كلها، ومنها شجاعته،

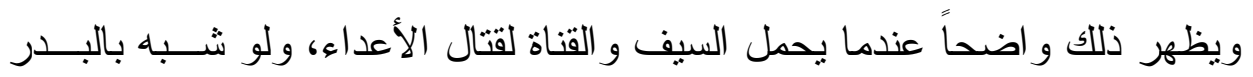

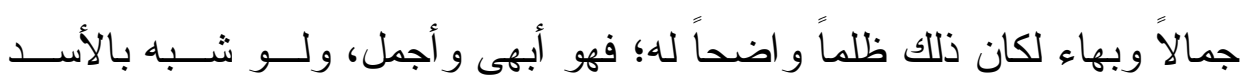

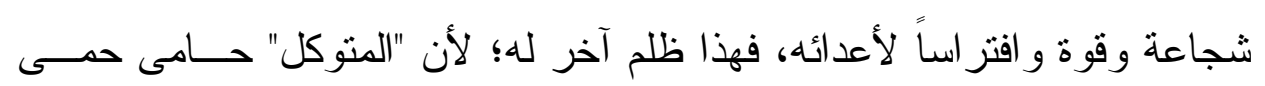

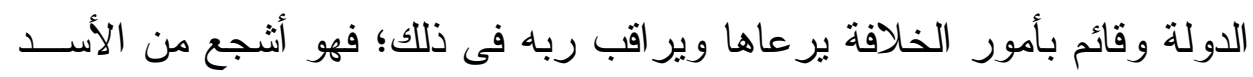
الذى يحمى عرينه فقط، ثم يضيف صورة أخرى وذللك إذا شبه "المتوكل" بالبحر

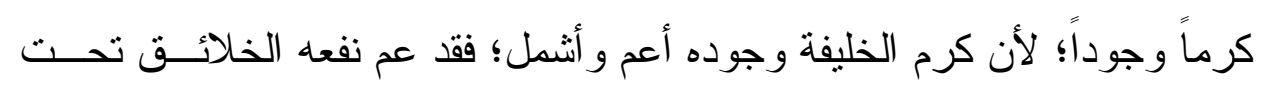

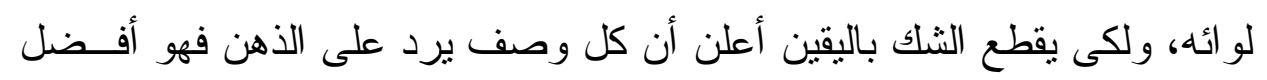
منه، وكل عطاء يصيب منه الناس فعطاؤه أكثر منه. من هنا حق للمسعودى أن يقول: "وله فى الحبس شعر معروف لم يـسبقه

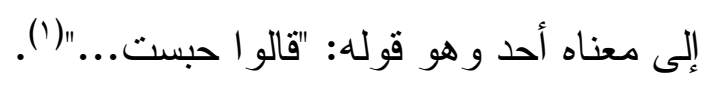

وحق لأبى الفرج الإصفهانى أن يقول: "و أحسن شعر قالـــهـ فـى الحــبس

$$
\text { قصيدته التى أولها قالت حبست" (؟). }
$$

وحق لابن خلكان أن يقول: "وله وقد حبس أبياته المشهورة التــى أولهــا

قالو ا حبست، و هى أبيات جيدة فى هذا المعنى ولم يعمل منلها"(؟). وحق لابن شرف القيرو انىى أن يقول: "و أما علــى بــن الجهـــ" فرشــيق الفهم... وله فى الغزل الرصافية، وفى العتاب الدالية، ولولم يكن لـــهـ ســـا اهما لكان أثنعر الناس بهما(؟).

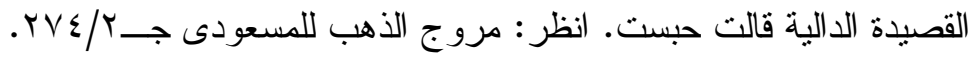

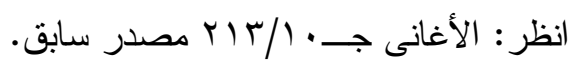

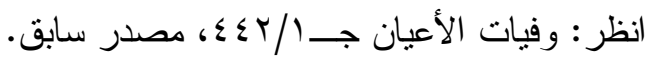

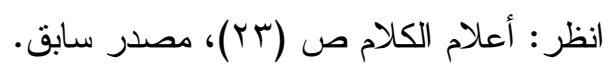


ونحن نؤيد ما قاله هؤلاء النقاد؛ فهو ينطر ح على ما شابه هذه القصيدة من

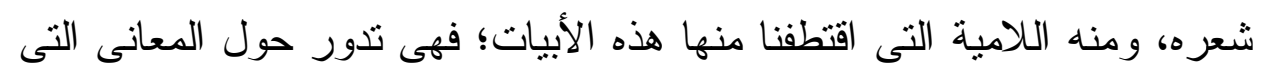
حملتها الدالية المشهورة. 


\section{ä}

وبعد؛ فهذا هو جهد المقل جرى حول دراسة أربعة أغر اض مــن شــعر

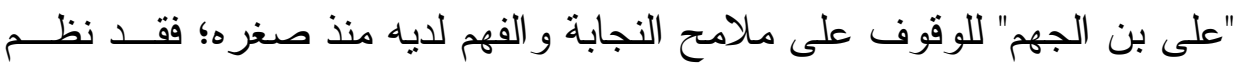

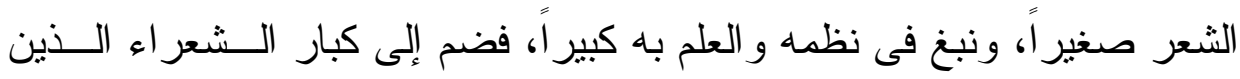
تفخر بهم اللغة العربية فى كل زمان ومكان؛ فقد ملكو ازمام الــصياغة الأدبيـــة

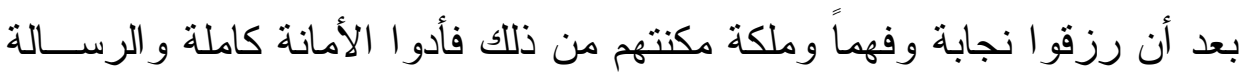
و اضحة جلية.

و أرجو - مخلصاً - أن أكون قد وفيت بما قد عزمت عليه، ونصبت جهدى

له، فإن كان ذلك التوفيق فمن الله و إن كان تقصير فمنى ومن الــشيطان، كمـــا

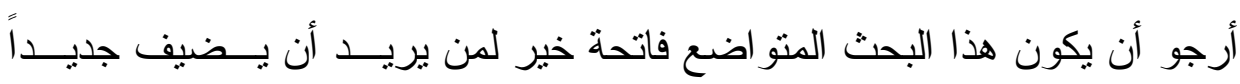

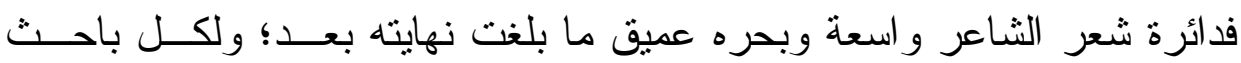
وسائله و أدو اته يستخرج جهرا من هذا البحر ياقوتاً ومرجاناً.

و الله من ور اء القصد، نسأله أن يوفقنا لخدمة لغة كتابه الكريم إنه ولى ذلك

و القادر عليه، وهو نعم المولى ونعم النصير

الأستاذ الدكتور

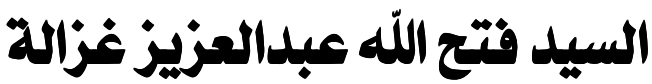

\section{أستاذ الأدب والنقد المساعد فى كلية اللغة \\ العربية فرع جامعة الأزهر بالمنوفية

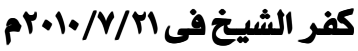




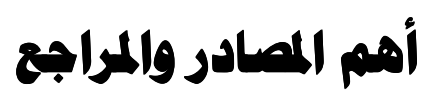

$$
\text { r- - القريث آل الكريث. }
$$

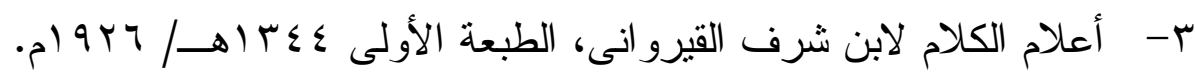

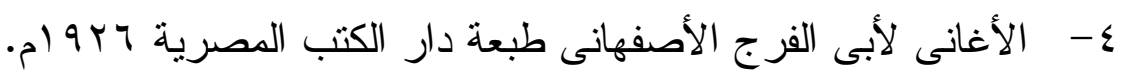

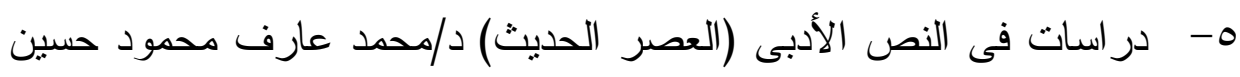

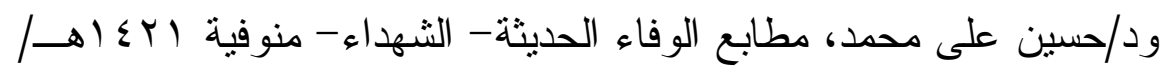

$$
\text { . }
$$

7- ديو ان "على بن الجهم" تحقيق خليل مردم بك، دار صادر بيروت- لبنــان . 1997

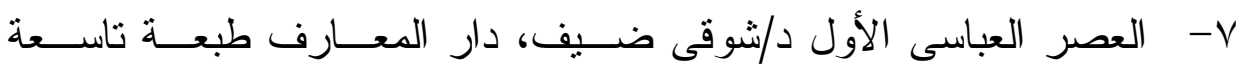
.01914

1- العمدة لابن رشيق القيرو انى تحقيق محمد محيى الــين عبدالحميـد، دار

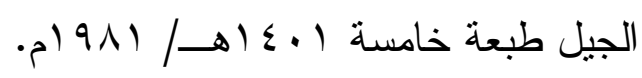

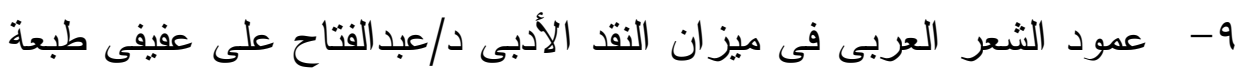

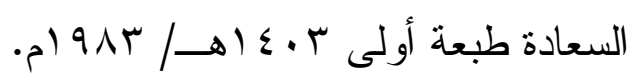

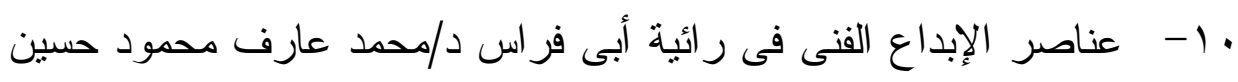

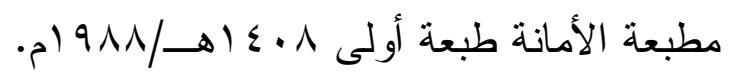

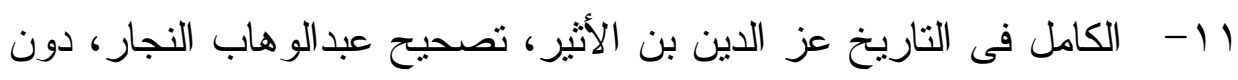

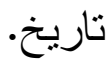




\section{ملامع النجابة والفهم فى شعر على بن الجهم}

r ا - مروج الذهب للمسعودى تحقيق يوسف أحمد داغر، نشر دار الأنـدلس،

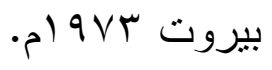

r ا - المعادل الموضوعى فى الثُعر الجاهلى د/كاظم الظو اهرى، دار الهدايـــة

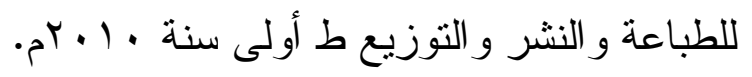

ع ا - موسيقى أوزان الثعر العربى دراسة تطبيقية د/السيد مرسى أبوذكرى ط

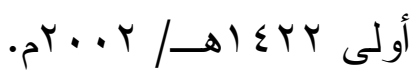

10- الموشح فى مآخذ العلماء على الثعر اء للمرزبانى، دار التأليف و الترجمة و النشر $9 \leq V$ (م.

7 ا - - نقد الشعر لأبى الفرج قدامة بن جعفر تحقيق وتعليق د/محمد عبــدالمنعم خفاجى دار الكتب العلمية، بيروت، لبنان. ا - النهاية لابن الأثثر فى غريب الحديث و الأثر. 11 - ـ وفيات الأعيان لابن خلكان، تحقيق إحسان عباس دار الثقافة، بيـروت، لبنان، دون تاريخ. 